\title{
Intramolecular C-H/O-H Bond Cleavage with Water and Alcohol using a Phosphine-Free Ruthenium Carbene NCN Pincer Complex
}

\author{
Demyan E. Prokopchuk \\ Brian T. H. Tsui \\ Alan J. Lough \\ Robert H. Morris
}

Version Post-print/accepted manuscript

Citation Prokopchuk, D. E.; Tsui, B. T. H.; Lough, A. J.; Morris, R. H. Chem. (published version) Eur. J. 2014, 20, 16960-16968.

http://dx.doi.org/10.1002/chem.201404819

\section{Copyright / License}
Publisher's Statement This is the peer reviewed version of the following article Prokopchuk, D. E.; Tsui, B. T. H.; Lough, A. J.; Morris, R. H. Chem. Eur. J. 2014, 20, 16960-16968 which has been published in final form at http://dx.doi.org/10.1002/chem.201404819. This article may be used for non-commercial purposes in accordance With Wiley-VCH Terms and Conditions for self-archiving.

\section{How to cite TSpace items}

Always cite the published version, so the author(s) will receive recognition through services that track citation counts, e.g. Scopus. If you need to cite the page number of the author manuscript from TSpace because you cannot access the published version, then cite the TSpace version in addition to the published version using the permanent URI (handle) found on the record page.

This article was made openly accessible by $U$ of $T$ Faculty. Please tell us how this access benefits you. Your story matters. 


\title{
Observed Intramolecular C-H/O-H Bond Cleavage with Water and Alcohol using a Phosphine-Free Ruthenium Carbene NCN Pincer Complex
}

\author{
Demyan E. Prokopchuk, Brian T. H. Tsui, Alan J. Lough, and Robert H. Morris ${ }^{*[a]}$ \\ [a] D. E. Prokopchuk, Brian T. H. Tsui, Dr. A. J. Lough, Prof. Dr. R. H Morris \\ Department of Chemistry \\ University of Toronto \\ 80 St. George Street, Toronto, ON, M5S 3H6 \\ E-mail: rmorris@chem.utoronto.ca
}

\begin{abstract}
Transition metal complexes that exhibit metal-ligand cooperative reactivity could be suitable candidates for applications in water splitting. Ideally, the ligands around the metal should not contain oxidizable donor atoms, such as phosphines. With this goal in mind, we report new phosphine-free ruthenium NCN pincer complexes with a central N-heterocyclic carbene donor and methylpyridyl $\mathrm{N}$-donors. Reaction with base generates a neutral, dearomatized alkoxo-amido complex, which has been structurally and spectroscopically characterized. The tert-butoxide ligand facilitates regioselective, intramolecular proton transfer through a $\mathrm{C}-\mathrm{H} / \mathrm{O}-\mathrm{H}$ bond cleavage process occurring at room temperature. Kinetic and thermodynamic data have been obtained by VT NMR experiments; DFT calculations support the observed behavior. Isolation and structural characterization of a doubly dearomatized phosphine complex also strongly supports our mechanistic proposal. The alkoxo-amido complex reacts with water to form a dearomatized ruthenium hydroxide complex, a first step towards phosphine-free metal-ligand cooperative water splitting.
\end{abstract}

\section{Introduction}

Transition metal complexes containing a Lewis basic ligand site that works together with a Lewis acidic metal center to cleave chemical bonds is commonly known as metal-ligand cooperation. In recent years, several groups have isolated and characterized reactive transition metal species that highlight the utility and importance of this design principle for applications in small molecule activation and catalysis. ${ }^{[1]}$ In particular, PNN pincer ligand systems incorporating a functionalized pyridine ring in the central ligating position are active catalysts for a variety of chemical transformations (Scheme 1). ${ }^{[2]}$ Active catalysts are generally prepared and/or isolated by deprotonation with a bulky external base, which dearomatizes the methylpyridyl fragment of the pincer ligand. With reactions involving alcohols, a key proposed step is $\mathrm{O}-\mathrm{H}$ splitting to generate a neutral alkoxide complex with subsequent rearomatization of the heterocycle. ${ }^{[3]}$ Other systems replacing the phosphine ligand arm with an $\mathrm{N}$-heterocyclic carbene have also been reported. ${ }^{[4]}$

Understanding the mechanism of metal-ligand cooperative $\mathrm{O}-\mathrm{H}$ splitting, especially with water, is relevant to renewable energy applications and the environment. ${ }^{[5]}$ In 2009, Milstein and co-workers reported a novel series of reactions in which a structurally characterized $\mathrm{RuH}(\mathrm{OH})(\mathrm{PNN})(\mathrm{CO})$ pincer complex can split water into $\mathrm{H}_{2}$ and $\mathrm{O}_{2}$ in two discrete steps using only heat and light (PNN=2-(di-tert-butylphosphinomethyl-6-diethylaminomethyl)pyridine) ${ }^{[6]}$ This is a first step forward in designing well-defined systems that can catalytically generate $\mathrm{H}_{2}$ and $\mathrm{O}_{2}$ in a clean, atom-efficient manner.

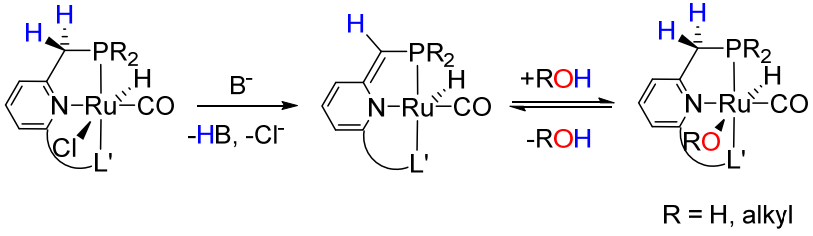

Scheme 1. General deprotonation behavior and $\mathrm{O}-\mathrm{H}$ activation using pyridine-centered Ru-PNL pincer complexes, where $\mathrm{L}=\mathrm{N}$ or $\mathrm{P}$ with the curved line representing various linkers.

Ideally, suitable catalyst candidates for water splitting do not contain oxidizable donor atoms such as phosphines that might readily react with $\mathrm{H}_{2} \mathrm{O}^{[7]}$ or $\mathrm{O}_{2}{ }^{[8]}\left(2 \mathrm{H}_{2} \mathrm{O} \rightarrow 2 \mathrm{H}_{2}+\mathrm{O}_{2}\right.$; $\mathrm{E}_{\mathrm{rxn}}=-1.23 \mathrm{~V}$ vs. SHE). Although the standard oxidation potential of pyridine is $+1.6 \mathrm{~V}$ (versus $1 \mathrm{M} \mathrm{Ag} / \mathrm{AgNO}_{3}$ ), ${ }^{[9]}$ pyridine-containing chelates are widely used for the catalytic oxidation of $\mathrm{H}_{2} \mathrm{O}$ to $\mathrm{O}_{2}$ by using a sacrificial reductant. ${ }^{[10]}$ Furthermore, research into the oxidation of $\mathrm{N}$-heterocyclic carbenes (NHCs) is limited, with a few known examples involving free $\mathrm{NHCs}^{[11]}$ and some $\mathrm{NHC}$ ligands bound to $\mathrm{Cu}^{[12]}$ and $\mathrm{Rh}^{[13]}$ capable of being oxidized in the presence of $\mathrm{O}_{2}$. In our efforts to design a phosphine-free cooperative metal-ligand system that could be suitable for 
water splitting, we present a carbene-centered NCN pincer ligand platform that undergoes regioselective, intramolecular C$\mathrm{H} / \mathrm{O}-\mathrm{H}$ proton exchange at room temperature by aromatization/dearomatization of the two outer pyridine rings. This is facilitated by a coordinated tert-butoxide ion, demonstrating that the bulky alkoxide base plays an important role in the coordination sphere of the metal by acting as an "intraligand" proton shuttle, which has not been previously observed in other metal-ligand cooperative systems. A rare dearomatized ruthenium tert-butoxide complex has been spectroscopically and structurally characterized, while NMR kinetic studies and DFT calculations strongly support the proposed proton shuttle mechanism. A phosphine trapping experiment further validates our mechanistic proposal, allowing us to structurally characterize the first example of a neutral, doubly dearomatized Ru-NCN pincer complex. Initial experiments show that the alkoxo-amido complex reacts with water to form a dearomatized ruthenium hydroxide complex, a first step towards designing new metal-ligand cooperative systems for water splitting.

\section{Results and Discussion}

The synthesis begins by preparing the imidazolium salt 1,3-di(2-methylpyridyl)-4,5-diphenylimidazolium bromide (1, Scheme 2) in two steps using commercially available reagents. ${ }^{[14]}$ Next, $\mathbf{1}$ is reacted with silver oxide in the presence of activated $3 \AA$ molecular sieves to generate the silver carbene transfer agent $\mathbf{2}$ in good yield. It is important to note the yield of 2 is low and/or inconsistent if $3 \AA$ molecular sieves are omitted or insufficiently dried. Water released during the reaction with silver oxide deactivates the imidazolium salt and dry solvent in combination with activated molecular sieves must be used. The monosubstituted carbene configuration of 2 , as opposed to being a bis(carbene) silver salt, ${ }^{[15]}$ was confirmed by elemental analysis. Installation of the NCN pincer ligand onto ruthenium was achieved by transmetalation from 2 using $\left[\mathrm{RuCl}_{2}(\mathrm{NBD})\right]_{\mathrm{n}}$ (NBD = bicyclo[2.2.1]hepta-2,5-diene), followed by salt metathesis using sodium or potassium hexafluorophosphate to obtain the tris-acetonitrile complex $\left[\mathrm{Ru}(\mathrm{NCN})(\mathrm{NCMe})_{3}\right]\left[\mathrm{PF}_{6}\right]_{2}(3)$. Two of the acetonitrile ligands are easily displaced by refluxing in the presence of ${ }^{\mathrm{B}} \mathrm{Bu}_{2}$ bpy $\left(4,4\right.$ '-Di-tert-butyl-2,2'-dipyridyl) to produce $\left[\mathrm{Ru}(\mathrm{NCN})\left({ }^{\mathrm{t}} \mathrm{Bu}_{2} \mathrm{bpy}\right)(\mathrm{NCMe})\right]\left[\mathrm{PF}_{6}\right]_{2}$ (4). To remove the third acetonitrile ligand, heating 4 in the presence of excess potassium bromide followed by alumina column purification yields the deep red-orange solid $\left[\mathrm{RuBr}(\mathrm{NCN})\left({ }^{\mathrm{B}} \mathrm{Bu}_{2} \mathrm{bpy}\right)\right]\left[\mathrm{PF}_{6}\right](\mathbf{5})$. Complex $\mathbf{5}$ is deeply colored and absorbs strongly between 300 and $700 \mathrm{~nm}$, with broad signals centered at $444 \mathrm{~nm}\left(\varepsilon=7000 \mathrm{M}^{-1} \mathrm{~cm}^{-1}\right)$ and $352 \mathrm{~nm}\left(\varepsilon=10000 \mathrm{M}^{-1} \mathrm{~cm}^{-1}\right)$. The syntheses of $2-5$ are performed under air and moisture free conditions, but the final products are conveniently stable in air/moisture. Using a suite of 1D and 2D NMR spectroscopic techniques, complexes 1-5 were fully characterized in solution. In particular, $\mathbf{4}$ and $\mathbf{5}$ exhibit characteristic ${ }^{1} \mathrm{H}$ NOESY signals, as indicated in Scheme 2. The molecular structures of $\mathbf{1}$ and $\mathbf{3}$ have also been obtained by single crystal X-ray diffraction (see the Supporting Information). ${ }^{[16]}$

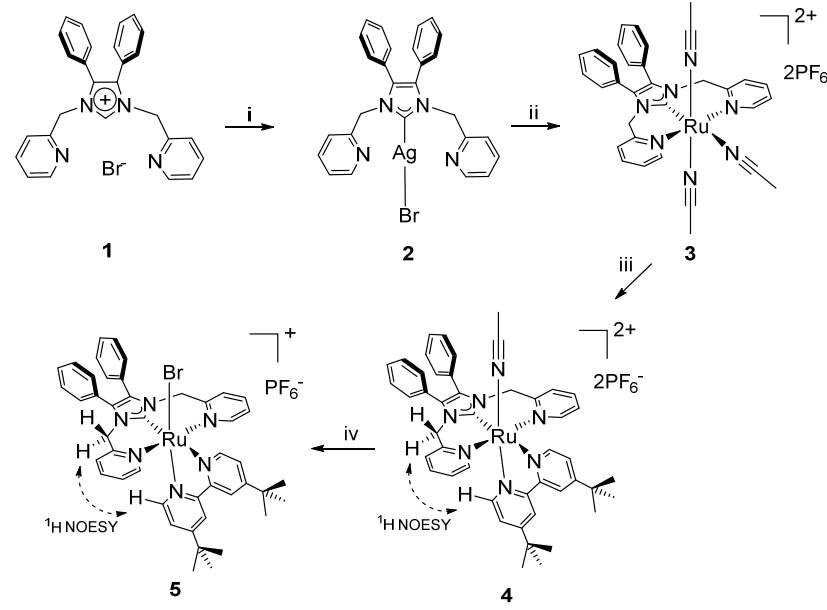

Scheme 2. Synthesis of compounds 1-5. (i) $\mathrm{Ag}_{2} \mathrm{O}, \mathrm{CHCl}_{3}, 3 \AA$ sieves, $89 \%$; (ii) $\left[\mathrm{RuCl}_{2}(\mathrm{NBD})\right]_{\mathrm{n}}, \mathrm{CH}_{3} \mathrm{CN} / \mathrm{CHCl}_{3}, 60^{\circ} \mathrm{C}$, then $\mathrm{MPF}_{6}(\mathrm{M}=\mathrm{Na}, \mathrm{K})$, $60 \%$; (iii) ${ }^{\mathrm{t}} \mathrm{Bu}_{2} \mathrm{bpy},\left(\mathrm{CH}_{3}\right)_{2} \mathrm{CO}$, reflux, $89 \%$; (iv) $\mathrm{KBr},\left(\mathrm{CH}_{3}\right)_{2} \mathrm{SO}, 110{ }^{\circ} \mathrm{C}$,

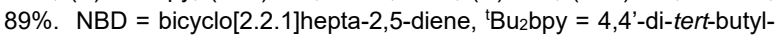
2,2'-dipyridyl, THF = tetrahydrofuran.

Next, complex 5 was reacted with potassium tertbutoxide under an argon atmosphere to determine if deprotonation at the methylene position was possible, resulting in dearomatization of the pyridine ring. The addition of two equivalents potassium tert-butoxide to a suspension of deep red-orange $\mathbf{5}$ in THF generates a deep maroon-purple solution in high yield (95\%) that is sensitive to air and moisture. Crystals suitable for X-ray diffraction revealed the compound to be the neutral, dearomatized, alkoxo-amido complex $\mathrm{Ru}\left(\mathrm{O}^{\mathrm{t}} \mathrm{Bu}\right)\left(\mathrm{NCN}^{*}\right)\left({ }^{\mathrm{B}} \mathrm{Bu}_{2} \mathrm{bpy}\right) \quad(6$, Scheme 3 and Figure 1). ${ }^{[17]}$ Similar to 5 , complex $\mathbf{6}$ is also deeply colored, possessing broad and intense absorbance signals at $487 \mathrm{~nm}\left(\varepsilon=7000 \mathrm{M}^{-1} \mathrm{~cm}^{-1}\right)$ and $378 \mathrm{~nm}\left(\varepsilon=10000 \mathrm{M}^{-1} \mathrm{~cm}^{-1}\right)$.

The molecular structure of 6 has some notable features. A tert-butoxide ligand occupies the apical position, possessing an unusually long Ru-O bond length of 2.111(2) $\AA .{ }^{[18]}$ Tert-butoxide bound ruthenium complexes are rare and have only been structurally characterized in distorted tetrahedral complexes containing one or more phosphine ligands. ${ }^{[18]}$ One of the methylene protons has indeed been deprotonated, leading to dearomatization of the pyridine moiety and shortening of bonds C22-C23 (1.377(4) $\AA$ ), C24-25 (1.348(4) $\AA$ ), and C26-27 (1.357(4) $\AA$ ) (Figure 1). Finally, there is a strong interaction between the oxygen atom and a methylene hydrogen $(\mathrm{O} 1 \cdots \mathrm{H} 16 \mathrm{~A}=2.341 \AA)$, situated about $0.4 \AA$ closer together than the sum of their Van der Waals radii. 


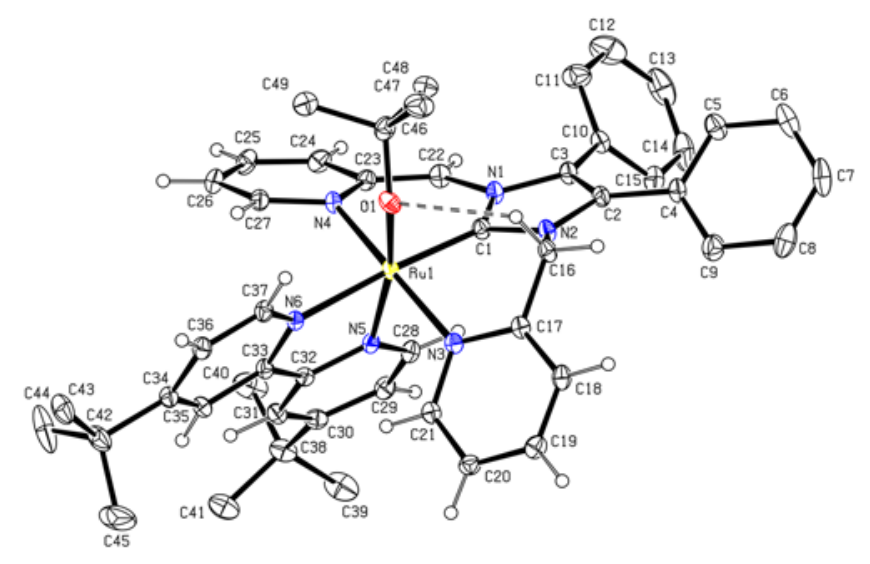

Figure 1. Molecular structure of 6 with ellipsoids at the $30 \%$ probability level. Phenyl and methyl hydrogens have been omitted for clarity. Distances $(\AA)$ and angles $\left({ }^{\circ}\right)$ : Ru1-O1=2.111(2), Ru1-C1=1.955(3), Ru1-N3=2.101(2), Ru1-N4=2.116(2), Ru1-N5=2.041(2), Ru1-N6=2.102(2), C22-C23=1.377(4), $\mathrm{O} 1 \cdots \mathrm{H} 16 \mathrm{~A}=2.341, \mathrm{~N} 5-\mathrm{Ru} 1-\mathrm{N} 6=78.04(8), \mathrm{N} 3-\mathrm{Ru} 1-\mathrm{C} 1=87.13(10)$, N4-Ru-C1=88.92(10), O1-Ru1-C1=93.30(10).

Complex 6 was also analyzed in detail by solution state NMR spectroscopy. At $25{ }^{\circ} \mathrm{C}$ in THF- $d_{8},{ }^{1} \mathrm{H}$ NMR signals belonging to the pincer ligand are broad while the ${ }^{\mathrm{t}} \mathrm{Bu}_{2} \mathrm{bpy}$ proton resonances are sharp. Cooling the NMR sample to $0{ }^{\circ} \mathrm{C}$ sharpens and resolves the pincer ligand signals, allowing for complete 1D and 2D NMR characterization of 6 (see the Supporting Information). Diagnostic ${ }^{1} \mathrm{H}$ NMR signals include the vinylic $\mathrm{CH}$

singlet at $5.06 \mathrm{ppm}$ (attached to C22, Figure 1) corresponding to the exocyclic proton of the pincer ligand, and the diastereotopic methylene doublets appearing at 4.74 and $6.47 \mathrm{ppm}$ (attached to C16, Figure 1).

The ${ }^{1} \mathrm{H}-{ }^{1} \mathrm{H}$ NOESY pulse sequence at $0{ }^{\circ} \mathrm{C}$ reveals unique chemical exchange (EXSY) cross peaks, where each proton on the pincer ligand framework is undergoing two-site chemical exchange; $a^{1} \mathrm{H}-{ }^{1} \mathrm{H}$ ROESY experiment confirms that the crosspeaks in phase with the diagonal were indeed due to chemical exchange (see the Supporting Information). The observed twosite chemical exchange is due to regioselective $\mathrm{C}-\mathrm{H} / \mathrm{O}-\mathrm{H}$ hydrogen transfer, where the tert-butoxide ligand acts as a proton shuttle between both sides of the pincer ligand (Scheme 4). The absence of an EXSY cross peak for the $\mathrm{CH}_{2}$ doublet at 6.47 ppm suggests that this is the proton undergoing intramolecular exchange (Scheme 4, red $\mathrm{H}$ atom). This process could occur through a doubly deprotonated/dearomatized intermediate 7 , which we were unable to observe at elevated temperatures. ${ }^{[19]}$ Instead, a phosphine trapping experiment and DFT calculations were performed (vide infra).

We conducted variable temperature (VT) ${ }^{1} \mathrm{H}$ NMR spectroscopy in THF- $d_{8}\left(0-50^{\circ} \mathrm{C}\right)$ and observed selective broadening of protons on the pincer ligand while all the signals on ${ }^{\mathrm{t}} \mathrm{Bu}_{2} \mathrm{bpy}$ remained sharp (see the Supporting Information). VT-NMR experiments of the crude reaction mixture in THF- $d_{8}$, which contains free tert-butanol and potassium tert-butoxide, reveals 
nearly identical proton chemical shifts and peak broadening behavior when compared to a pure sample of 6 , suggesting that proton transfer is intramolecular.

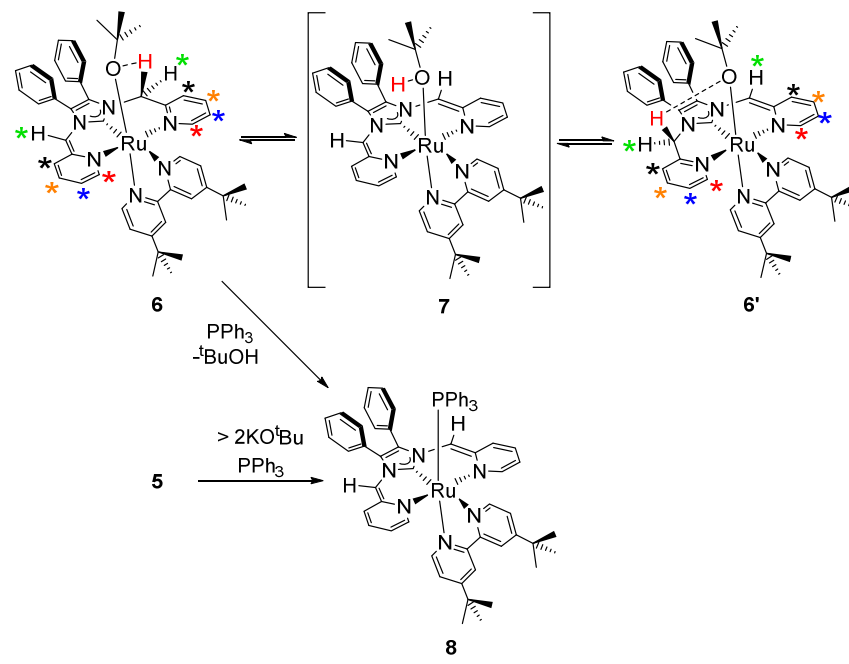

Scheme 4. Top: intramolecular proton exchange behavior of 6 in solution with proposed intermediate 7; the color-matched asterisks indicate the protons on the pincer framework undergoing two-site chemical exchange while the red proton is being transferred. Bottom: trapping experiments with $\mathrm{PPh}_{3}$, generating doubly dearomatized complex 8 .

To support the presence of doubly deprotonated intermediate 7, we performed a phosphine trapping experiment either by addition of $\mathrm{PPh}_{3}$ to $\mathbf{6}$, or addition of $\mathrm{PPh}_{3}$ to 5 with excess base (Scheme 4). A new deep orange compound forms with a characteristic ${ }^{31} \mathrm{P}$ NMR singlet at $59.5 \mathrm{ppm}$ and a vinylic ${ }^{1} \mathrm{H}$ NMR singlet at 4.53 ppm. NMR spectroscopic and X-ray crystallographic characterization $^{[20]}$ unambiguously confirm that this complex is indeed the doubly deprotonated/dearomatized ${ }^{[21]}$ $\mathrm{Ru}\left(\mathrm{NCN}^{* *}\right)\left({ }^{\mathrm{t}} \mathrm{Bu}_{2} \mathrm{bpy}\right)(\mathrm{PPh} 3)(\mathbf{8}$, Figure 2).

According to the NMR spectroscopic data, 8 is $\mathrm{C}_{s}$ symmetric in solution, however the molecular structure reveals that one of the pincer arms is tilted significantly out of plane with respect to the $\mathrm{N}$-heterocyclic carbene, with a dihedral angle of $\mathrm{C} 1 \mathrm{~A}-\mathrm{N} 2 \mathrm{~A}-\mathrm{C} 22 \mathrm{~A}-\mathrm{C} 23 \mathrm{~A}=-23.46^{\circ}$ (Figure 2 ). The bond lengths of each pincer ligand arm of $\mathbf{8}$ resemble that of the monodearomatized portion of $\mathbf{6}$. Double deprotonation of related $\mathrm{Re},{ }^{[22]} \mathrm{Rh},{ }^{[23]} \mathrm{Pd} / \mathrm{Pt},{ }^{[24]}$ and $\mathrm{Ni}{ }^{[25]} \mathrm{PNP}$ pincer systems with a central 2,6-dimethylpyridyl moiety have been described elsewhere; to the best of our knowledge, this is the first reported pincer complex that contains two independently dearomatized pyridine rings.

The regiospecific chemical exchange of 6 was modeled using dynamic NMR (DNMR) simulations (Figure 5). The $\mathrm{CH}_{2}$ protons and $\mathrm{CH}$ proton on the pincer ligand system, attached to carbons $\mathrm{C} 16$ and $\mathrm{C} 22$ (Figure 1), were modeled as a two-site $\mathrm{ABC} \leftrightarrow \mathrm{BAC}$ mutual exchange system using the $\mathrm{DNMR}^{[26]}$ simulation package ${ }^{[27]}$ Excellent line fitting was achieved, allowing us to use the rate constants to obtain activation parameters by Eyring plot analysis (Table 1; see the Supporting Information). The small entropy contribution $\left(\Delta \mathbf{S}^{\ddagger}=-1.5 \pm 1.7 \mathrm{cal} \mathrm{mol}^{-1} \mathrm{~K}^{-1}\right)$, is consistent with this being an intramolecular chemical exchange process. ${ }^{[28]}$

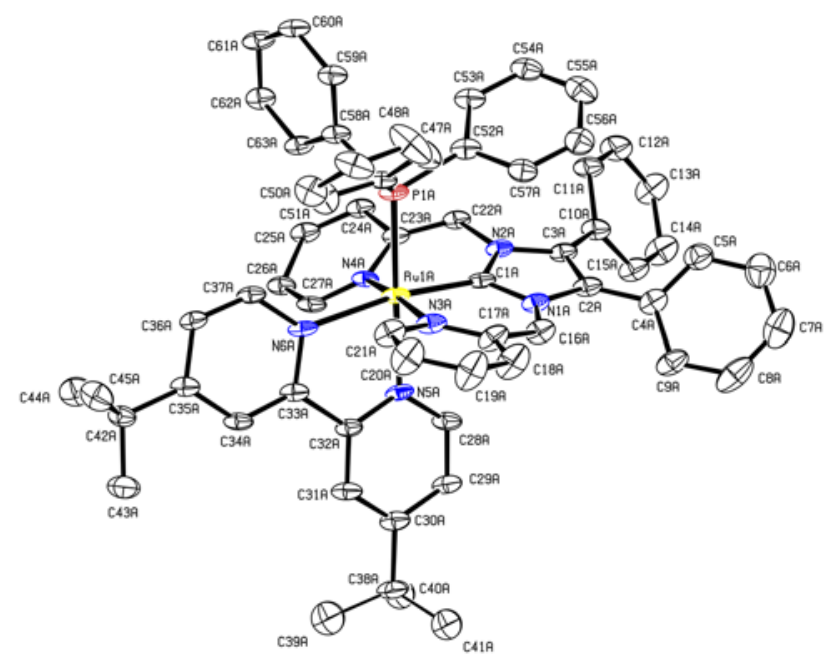

Figure 2. Molecular structure of $\mathbf{8}$ with ellipsoids at the $30 \%$ probability level. Only one of the two crystallographically independent complexes is shown. Hydrogen atoms have been omitted for clarity. Distances $(\AA)$ and angles $\left({ }^{\circ}\right)$ : Ru1A-P1A=2.3187(14), Ru1A-C1A=1.966(7), Ru1A-N3A=2.121(5), Ru1AN4A=2.131(5), Ru1A-N5A=2.104(4), Ru1A-N6A=2.155(6), C16A-C17A=1.366(10), C22A-C23A=1.348(10), N5A-Ru1A-N6A=76.58(19), N3A-Ru1A$\mathrm{C} 1 \mathrm{~A}=90.3(2), \mathrm{N} 4 \mathrm{~A}-\mathrm{RuA}-\mathrm{C} 1 \mathrm{~A}=87.1(2), \mathrm{C} 1 \mathrm{~A}-\mathrm{N} 1 \mathrm{~A}-\mathrm{C} 16 \mathrm{~A}-\mathrm{C} 17 \mathrm{~A}=-3.98, \mathrm{C} 1 \mathrm{~A}-\mathrm{N} 2 \mathrm{~A}-\mathrm{C} 22 \mathrm{~A}-\mathrm{C} 23 \mathrm{~A}=-23.46$.

Density Functional Theory (DFT) calculations ${ }^{[29]}$ were performed to determine if the observed energy barriers between 6 and the proposed doubly dearomatized complex 7 corresponded with our experimental observations. We chose to use the M06-L ${ }^{[30]}$ DFT functional combined with the TZVP ${ }^{[31]} / T Z V P F i t$ basis sets on all atoms (except QZVP[32] for Ru) since accurate thermochemical parameters were recently obtained for other organometallic reactions. ${ }^{[3]}$ Ground state structures for the 
alkoxide (6) and doubly dearomatized alcohol adduct (7) were found, along with a transition state structure (TS 6,7$)($ Figure 4). The calculated ground state free energy of 7 is $11.5 \mathrm{kcal} \mathrm{mol}{ }^{-1}$ higher in energy than 6 , close to that of $\operatorname{TS}_{6,7}\left(\Delta \mathrm{G}_{298}{ }^{\ddagger}=15.7\right.$ kcal mol-1, see the Supporting Information).

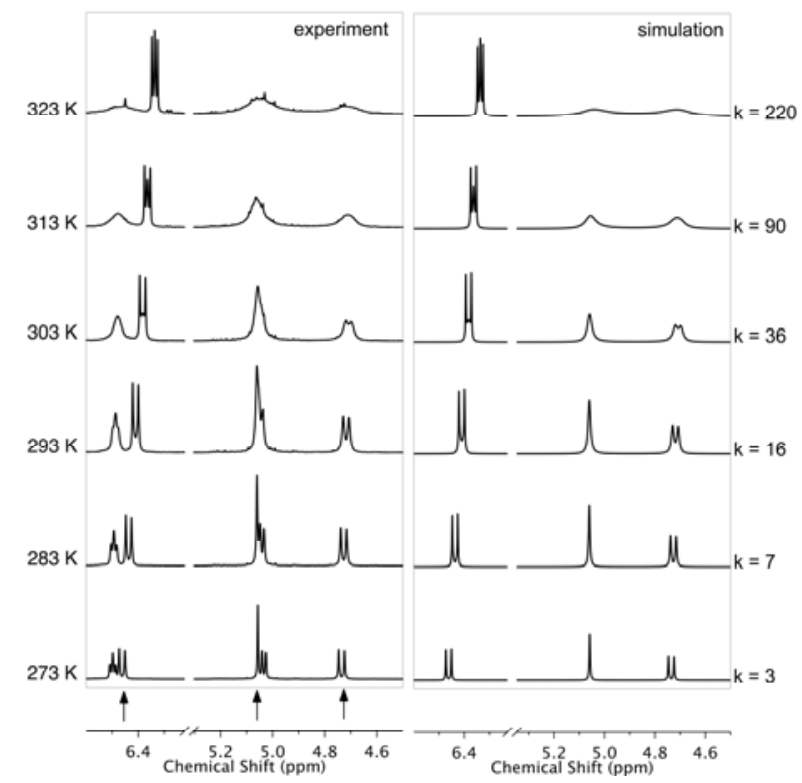

Figure 4. Selected chemical shift regions of experimental NMR ${ }^{1} \mathrm{H}$ spectra of 6 (left, THF- $d_{8}, 600 \mathrm{MHz}$ ) at various temperatures and simulated NMR spectra (right) with rate constants $\left(\mathrm{s}^{-1}\right)$. Arrows indicate the exchange peaks of interest that were modeled in the simulation.

Table 1. Experimental (entry 1) and calculated (entry 2) activation parameters for intramolecular proton transfer $(\mathbf{6} \rightarrow \mathbf{7})$.

\begin{tabular}{cccc}
\hline Sample & $\boldsymbol{\Delta} \mathbf{H}^{\ddagger}\left(\mathrm{kcal} \mathrm{mol}^{-1}\right)$ & $\boldsymbol{\Delta} \mathbf{S}^{\ddagger}\left(\mathrm{cal} \mathrm{mol}^{-1} \mathbf{K}^{-1}\right)$ & $\Delta \mathbf{G}_{\mathbf{2 9 8}}{ }^{\ddagger}\left(\mathrm{kcal} \mathrm{mol}^{-1}\right)$ \\
\hline $\mathbf{6} \rightarrow \mathbf{7}$ (exp.) & $14 \pm 1$ & $-1.5 \pm 1.7$ & $15 \pm 1$ \\
$\mathbf{6} \rightarrow \mathbf{7}$ (calc.) & 15.8 & 0.2 & 15.7 \\
\hline
\end{tabular}

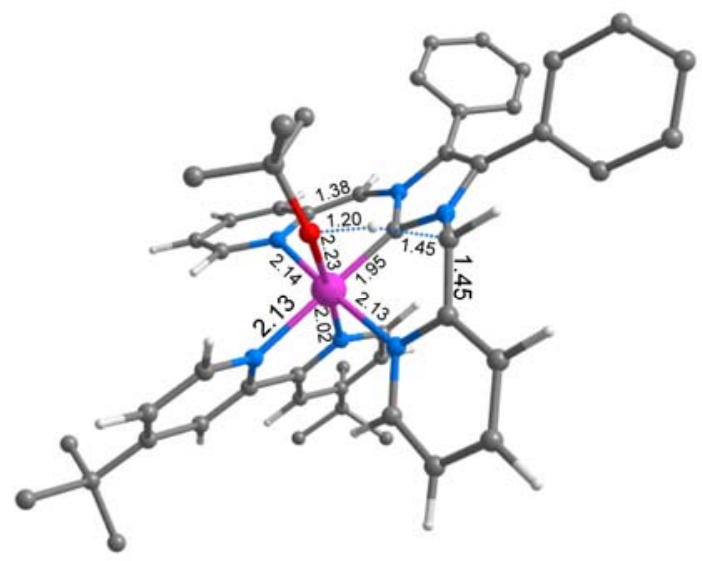

Figure 5. Transition state geometry of $\mathbf{T S}_{6,7}(v=1160 i)$. Distances are in Angstroms $(\AA)$.

When 6 is exposed to water, the deep maroon-purple solution turns deep maroon-orange, replacing the tert-butoxide moiety with hydroxide to generate the compound $\mathrm{Ru}(\mathrm{OH})\left(\mathrm{NCN}^{*}\right)\left({ }^{\left.\mathrm{t} B \mathrm{Bu}_{2} \mathrm{bpy}\right)}(\mathbf{9}\right.$, Scheme 5$)$. The NMR signals corresponding to 9 are similar to that of 6, revealing intramolecular chemical exchange by ${ }^{1} \mathrm{H}-{ }^{1} \mathrm{H}$ ROESY and a broad Ru-OH signal at $-2.4 \mathrm{ppm}$ $\left(0^{\circ} \mathrm{C}\right)$ in the ${ }^{1} \mathrm{H}$ spectrum (see the Supporting Information). Reaction of 6 with $\mathrm{D}_{2} \mathrm{O}$ reveals deuterium incorporation at exactly four sites, with the affected ${ }^{1} \mathrm{H}$ NMR signals integrating to about $50 \%$ of their original value. This suggests that the substitution 
of tert-butanol for hydroxide is not stereoselective, whereas with other pincer systems $\mathrm{D}_{2} \mathrm{O}$ splitting only deuterates one ligand site. ${ }^{[6 a]}$

Scheme 5. Reaction of 6 with $\mathrm{H}_{2} \mathrm{O}$ or $\mathrm{D}_{2} \mathrm{O}$.

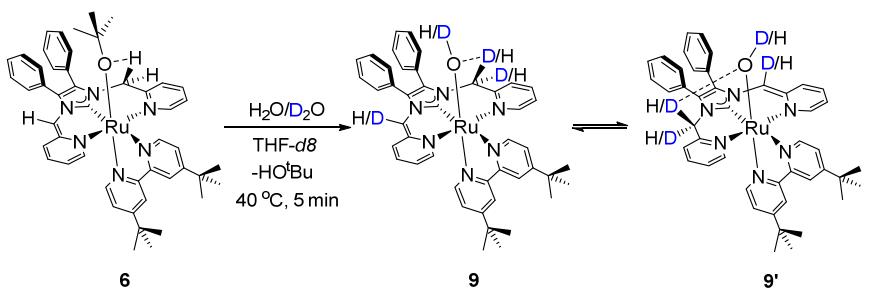
are employed. VT-NMR data, DNMR simulations, phosphine trapping experiments, and DFT calculations of the proton shuttle mechanism of $\mathbf{6}$ are all are in excellent agreement with one another. The deeply colored nature of these compounds is encouraging for future use in photochemical reactions. We believe that compounds $\mathbf{6}$ and $\mathbf{9}$ are promising entry points into well-defined systems capable of water splitting, which our lab is currently investigating.

\section{Experimental Section}

All reactions containing silver or ruthenium reagents were carried out in an argon atmosphere (5.0 grade, ultra high purity) using standard Schlenk and glove box techniques using air and moisture free solvents/reagents unless otherwise stated. Di$\mu$-chloro-( $\eta^{4}$-bicyclo[2.2.1] hepta-2,5- diene)ruthenium(II) polymer was synthesized according to known literature procedures. ${ }^{[34]}$ Potassium tert-butoxide (sublimed) and triphenylphospshine were purchased from Aldrich and stored in an argon-filled glove box. Alumina (activated, neutral, Brockmann I) was purchased from Aldrich and used as received. Silver(I) oxide was purchased from Aldrich and stored in an argon-filled glove box protected from light. Dichloromethane and acetonitrile were refluxed over calcium hydride, distilled, and stored under argon. Acetone was refluxed over phosphorus pentoxide, distilled, and stored under argon. Air and moisture free dimethylsulfoxide was purchased from Aldrich and stored under argon. Pentane was refluxed over $\mathrm{Na}$ /benzophenone, distilled, and stored under argon. Tetrahydrofuran was refluxed over sodium/benzophenone, distilled, and stored under argon with activated $3 \AA$ molecular sieves $(20 \%$ w/v). Toluene was refluxed over sodium, distilled, and stored under argon. Degassed $\mathrm{H}_{2} \mathrm{O} / \mathrm{D}_{2} \mathrm{O}$ was prepared by pouring distilled/deionized water (or $\mathrm{D}_{2} \mathrm{O}$ purchased from Cambridge Isotope Laboratories) into a Schlenk flask, applying high vacuum for about one minute, and then sonicating for 5 minutes to remove dissolved gases. The vacuum/sonication steps were repeated twice more after which the vessel was filled with argon. Molecular sieves $(3 \AA)$ were activated by heating at $300^{\circ} \mathrm{C}$ under high vacuum for $2-3$ days and were stored in an argon-filled glove box. Acetonitrile- $d_{3}$ and chloroform- $d$ were purchased from Cambridge Isotope Laboratories and used as received. Tetrahydrofuran- $d_{8}$ and toluene- $d_{8}$ were purchased in individually packaged ampoules from Aldrich and dried in an argon-filled glove box over activated $3 \AA$ molecular sieves $(20 \% \mathrm{w} / \mathrm{v})$. All other solvents/reagents were used as received without further purification. NMR spectra with compound numbering schemes, X-ray crystal structure and refinement data for $\mathbf{1 , 3 , 6 , 8}$, and DFT Cartesian coordinates, are provided in the Supporting Information.

All NMR spectroscopic data were collected using an Agilent DD2 $500 \mathrm{MHz}$ spectrometer with an Agilent HC 5-mm XSens cryogenically-cooled probe $\left(500 \mathrm{MHz}\right.$ for ${ }^{1} \mathrm{H}, 126 \mathrm{MHz}$ for ${ }^{13} \mathrm{C}$,), Agilent DD2 $600 \mathrm{MHz}$ spectrometer with an Agilent 5-mm OneNMR Probe $\left(600 \mathrm{MHz}\right.$ for ${ }^{1} \mathrm{H}, 151 \mathrm{MHz}$ for ${ }^{13} \mathrm{C}, 243 \mathrm{MHz}$ for $\left.{ }^{31} \mathrm{P}\right)$, or Bruker Avance III 400 spectrometer $\left(400 \mathrm{MHz}\right.$ for ${ }^{1} \mathrm{H}$, $101 \mathrm{MHz}$ for ${ }^{13} \mathrm{C}$ ). All ${ }^{1} \mathrm{H}$ and ${ }^{13} \mathrm{C}$ NMR samples were referenced to their respective residual solvent peaks ${ }^{[35]}$ and data was collected at $298 \mathrm{~K}$ unless stated otherwise. Coupling constant $J$ values are given in $\mathrm{Hz}$. Spectral data was processed using MNova 9.0. Variable temperature ${ }^{1} \mathrm{H}$ NMR analysis of 6 was collected at spectrometer frequency of $600 \mathrm{MHZ}$ between $0{ }^{\circ} \mathrm{C}$ and $50{ }^{\circ} \mathrm{C}$. The probe temperature was calibrated using a $100 \%$ ethylene glycol standard ${ }^{[36]}$ in a flame sealed NMR tube supplied by Cambridge Iso- tope Laboratories. VT airflow was set to $10 \mathrm{~L} / \mathrm{min}$ and deviation from from desired temperatures was no more than $0.25^{\circ} \mathrm{C}$. Dynamic NMR simulations were performed using the DNMR3 ${ }^{[26]}$ utility in Spinworks $4.0 .3 .^{[27]}$ The protons in 6 labelled as $\mathrm{H}_{b}(\mathrm{~A}), \mathrm{H} 28(\mathrm{~B})$, and $\mathrm{H} 3_{a}(\mathrm{C})$ were modeled as an $\mathrm{ABC} \leftrightarrow \mathrm{BAC}$ spin system with $J(A, B)=0 \mathrm{~Hz}$ and $J(A, C)=J(B, C)=13.2 \mathrm{~Hz}$. Simulations were modelled at $600 \mathrm{MHz}$ with a spectral window of $9615 \mathrm{~Hz}$, lowest frequency of $2321.8 \mathrm{~Hz}$, and 65536 points. Rate constants $k$ were obtained by systematic trial and error, modifying rate constant $(k)$ and relaxation $\left(T_{2}\right)$ parameters at until a best fit was achieved for each experimental NMR spectrum at a given temperature.

UV-vis spectra were recorded on a Hewlett-Packard Agilent 8453 UV-vis spectrophotometer. Elemental analyses were performed on a Perkin-Elmer 2400 or LECO TruSpec Micro CHN elemental analyzer. Single- crystal X-ray diffraction data were collected at $150 \mathrm{~K}$ using a Nonius Kappa-CCD diffractometer with Mo Ka radiation $(\lambda=0.71073 \AA)$. The CCD data were integrated and scaled using the Denzo-SMN package. ${ }^{[37]}$ The structures were solved and refined using SHELXTL V6.1. ${ }^{[38]}$ Refinement was by full-matrix least-squares on $F^{2}$ using all data. X-ray structure and refinement data are provided in the Supporting Information.

All DFT calculations were performed using Gaussian 09 (Revision B.01 or D.01). The M06-L[30] density functional with the TZVP ${ }^{[31]}$ (also known as def-TZVP) basis set with TZVPFit density fitting basis set for $\mathrm{C}, \mathrm{H}, \mathrm{N}, \mathrm{O}$ atoms was used and QZVP ${ }^{[32]}$ (also known as def2-QZVP) basis set was used for Ru. Normal convergence criteria were used for all optimizations and a pruned $(99,590)$ integration grid was used throughout (grid=ultrafine). Optimizations were performed in tetrahydrofuran solvent using the integral equation formalism polarizable continuum model (IEF- PCM) ${ }^{[39]}$ with radii and non-electrostatic terms from the SMD ${ }^{[40]}$ solvation model (scrf=smd). Full vibrational and thermochemical analyses ( $\left.1 \mathrm{~atm}, 298 \mathrm{~K}\right)$ were performed on 
optimized structures to obtain solvent-corrected free energies $\left(G^{\circ}\right.$ solv $)$ and enthalpies $\left(H^{\circ}\right.$ solv $)$. Optimized ground states were found to have zero imaginary frequencies while transition states had exactly one imaginary frequency. Three-dimensional visualizations of calculated structures were generated by ChemCraft. ${ }^{[41]}$

1-(2-methylpyridyl)-4,5-diphenylimidazole. This procedure has been adapted from a synthetic protocol for a similar compound. ${ }^{[42]}$ 4,5-diphenylimidazole $(31.6 \mathrm{mmol}, 6.97 \mathrm{~g}), 2$-(bromomethyl)pyridine hydrobromide $(31.6 \mathrm{mmol}, 8.00 \mathrm{~g}), \mathrm{KOH}$ $(127 \mathrm{mmol}, 7.1 \mathrm{~g})$, and a Teflon coated stir bar were added to a round bottom flask, followed addition of tetrahydrofuran (250 $\mathrm{mL})$. The solution was refluxed for 2 days. The solvent was removed, followed by addition of dichloromethane (200 $\mathrm{mL})$, and then the solution was washed with water $(2 \times 200 \mathrm{~mL})$ in a separatory funnel. The organic layer was dried with $\mathrm{MgSO}_{4}$, filtered, and solvent was removed. The solid was redissolved in tetrahydrofuran (about $20 \mathrm{~mL}$ ) and pentane was added (600 $\mathrm{mL}$ ) to precipitate a white solid. The product was collected on a medium-pore glass frit, washed with pentane $(30 \mathrm{~mL})$, and dried under high vacuum (8.61 g, 87\%). EA: Found: C 80.57, H 5.71, N 13.25. Calc. for $\mathrm{C}_{21} \mathrm{H}_{17} \mathrm{~N}_{3}: \mathrm{C} 81.00, \mathrm{H} 5.50, \mathrm{~N} \mathrm{13.49 \%}$. ${ }^{1} \mathrm{H}$ NMR (400 MHz; $\left.\mathrm{CDCl}_{3}\right): \delta=8.50(\mathrm{~m}, 1 \mathrm{H} ; \mathrm{H} 8), 7.73(\mathrm{~s}, 1 \mathrm{H} ; \mathrm{H} 1), 7.57(\mathrm{~m}, 1 \mathrm{H} ; \mathrm{H} 6), 7.50-7.47(2 \mathrm{H} ; \mathrm{Ph}), 7.38-7.32(3 \mathrm{H} ; \mathrm{Ph})$, 7.22-7.10 (5H; Ph), $7.17(\mathrm{~m}, 1 \mathrm{H} ; \mathrm{H} 7$ (buried under $\mathrm{Ph})), 6.76(\mathrm{~m}, 1 \mathrm{H} ; \mathrm{H} 5), 5.09(\mathrm{~s}, 2 \mathrm{H} ; \mathrm{H} 3) .{ }^{13} \mathrm{C}\left\{{ }^{1} \mathrm{H}\right\} \mathrm{NMR}: \delta=156.39(\mathrm{C} 4)$, 149.56 (C8), 138.35 (C9), 137.44 (C1), 136.95 (C6), 134.44-128.74 (Ph), 128.67 (C2), 128.08-126.34 (Ph), 122.66 (C7), 120.94 (C5), 50.33 (C3)

1,3-di(2-methylpyridyl)-4,5-diphenylimidazolium bromide (1). 1-(2-methylpyridyl)-4,5-diphenylimidazole (27.6 mmol, 8.61 g), 2-(bromomethyl)pyridine hydrobromide $(27.6 \mathrm{mmol}, 6.99 \mathrm{~g}), \mathrm{NaHCO}_{3}(55 \mathrm{mmol}, 4.6 \mathrm{~g})$, and a Teflon-coated stir bar were added to a round bottom flask, followed by addition of MeCN $(600 \mathrm{~mL})$. The solution was refluxed for 2 days. The deep red solution was dried and redissolved in $50 \mathrm{~mL}$ dichloromethane. The solids were filtered off and the filtrate was collected and dried under high vacuum. About $600 \mathrm{~mL}$ tetrahydrofuran was added and the suspension was stirred vigorously for several hours until the lumpy solid became a fine powder. The solid was isolated on a medium-pore glass frit, washed with tetrahydrofuran $(30 \mathrm{~mL})$, pentane $(30 \mathrm{~mL})$, and dried under vacuum to afford a pale tan-pink powder $(9.42 \mathrm{~g}, 70 \%)$. Crystals suitable for $\mathrm{X}$-ray diffraction were grown via bi-layer diffusion (diethyl ether/acetonitrile). EA: Found: C 66.67, H 5.15, N 11.66. Calc. for $\mathrm{C}_{27} \mathrm{H}_{23} \mathrm{BrN}_{4}$ : C 67.08, H 4.80, N 11.59\%. ${ }^{1} \mathrm{H}$ NMR (500 MHz; $\left.\mathrm{CDCl}_{3}\right): \delta=10.37(\mathrm{~s}, 1 \mathrm{H} ; \mathrm{H} 1), 8.50(\mathrm{~m}, 2 \mathrm{H} ; \mathrm{H} 8), 7.68$ (m, 2H; H6), 7.42 (m, 2H; H5), $7.36(\mathrm{~m}, 2 \mathrm{H} ; \mathrm{Ph}), 7.28(\mathrm{~m}, 4 \mathrm{H} ; \mathrm{Ph}), 7.24-7.21(\mathrm{~m}, 4 \mathrm{H} ; \mathrm{Ph}), 7.21(\mathrm{~m}, 2 \mathrm{H} ; \mathrm{H} 7$ (buried under Ph)), $5.64(\mathrm{~s}, 4 \mathrm{H} ; \mathrm{H} 3) .{ }^{13} \mathrm{C}\left\{{ }^{1} \mathrm{H}\right\} \mathrm{NMR}: \delta=152.75(\mathrm{C} 4), 149.70$ (C8), 138.67 (C1), 137.64 (C6), 132.37 (C2), 130.95-124.91 (Ph), 123.72 (C7), 123.15 (C5) 52.31 (C3).

Ag(NCN)Br (2). Compound 1 (18.6 mmol, $9.00 \mathrm{~g}$ ) and a Teflon coated stir bar were added to a Schlenk flask and placed under an inert atmosphere. Under argon, $\mathrm{Ag}_{2} \mathrm{O}(9.31 \mathrm{mmol}, 2.16 \mathrm{~g})$ and activated $3 \AA$ molecular sieves $(10 \mathrm{~g})$ were added, followed by dichloromethane $(120 \mathrm{~mL})$. The solution was vigorously stirred in the dark for 4 hours at room temperature. In air, about $250 \mathrm{~mL}$ chloroform was added to the solution, stirred for 15 minutes, then filtered through a pad of Celite. The Celite pad was washed with dichloromethane $(20 \mathrm{~mL})$ and then the solvent was removed from the brown solution. The residue was redissolved in $50 \mathrm{~mL}$ chloroform and about $600 \mathrm{~mL}$ diethyl ether was added to precipitate the product from the vigorously stirred solution. The solid was isolated on a medium-pore glass frit, washed with diethyl ether (20 mL), and dried under high vacuum to obtain a pale tan-pink solid $(9.79 \mathrm{~g}, 89 \%)$. The hygroscopic product is air and moisture stable. EA: Found: C 53.93 , $\mathrm{H} 3.68 \mathrm{~N}$ 9.39. Calc. for $\mathrm{C}_{27} \mathrm{H}_{22} \mathrm{~N}_{4} \mathrm{AgBr} \cdot(\mathrm{CHCl} 3)_{0.1}$ : $\mathrm{C} 54.05, \mathrm{H} 3.70, \mathrm{~N} \mathrm{9.30 \%}$. After multiple EA results from independent batches of product, carbon was consistently $1 \%$ lower than expected, leading us to conclude that about $10 \% \mathrm{CHCl} 3$ remains with the product. ${ }^{1} \mathrm{H}$ NMR $\left(400 \mathrm{MHz} ; \mathrm{CDCl}_{3}\right): \delta=8.50(\mathrm{~m}, 2 \mathrm{H} ; \mathrm{H} 8), 7.60(\mathrm{~m}, 2 \mathrm{H}, \mathrm{H} 6), 7.28-7.11(10 \mathrm{H} ; \mathrm{Ph}), 7.17(\mathrm{~m}, 2 \mathrm{H} ; \mathrm{H} 7$ (buried under $\mathrm{Ph}$ ), 7.08 (m, 2H, H5), 5.39 (s, 4H; H3). 13C $\left\{{ }^{1} \mathrm{H}\right\}$ NMR: $\delta=183.72(\mathrm{C} 1), 155.78(\mathrm{C} 4), 149.84$ (C8), 137.09 (C6), $132.11(\mathrm{C} 2), 130.76-127.78(\mathrm{Ph}), 122.99$ (C7), 122.07 (C5), 54.76 (C3).

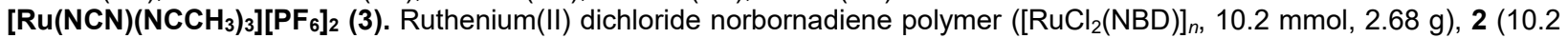
$\mathrm{mmol}, 6.00 \mathrm{~g}$ ), and a Teflon coated stir bar were added to a Schlenk flask and placed under an inert atmosphere. Chloroform $(80 \mathrm{~mL})$ and acetonitrile $(80 \mathrm{~mL})$ were added and the solution was stirred for $24 \mathrm{~h}$ at $60^{\circ} \mathrm{C}$. The solution was cooled to room temperature and $\mathrm{MPF}_{6}$ was added $(20.3 \mathrm{mmol}, 2$ equiv. with respect to $\mathrm{Ru}, \mathrm{M}=\mathrm{Na}$ or $\mathrm{K})$. The solution was stirred for $1 \mathrm{~h}$ at room temperature. In air, the solution was filtered through a pad of Celite which was washed with acetonitrile until the outgoing liquid was colourless. The yellow-orange solution was dried, and then 1,2-dimethoxyethane $(500 \mathrm{~mL})$ was added. This solution was vigorously stirred for several hours until a fine powder formed. The solid was collected on a medium-pore glass frit, washed with pentane $(20 \mathrm{~mL})$ and dried under high vacuum to afford a pale tan powder $(5.58 \mathrm{~g}, 60 \%)$. The product is air and moisture stable. Crystals suitable for X-ray diffraction were grown via bi-layer diffusion (diethyl ether/acetonitrile). The labile acetonitrile ligand trans to the $\mathrm{N}$-heterocyclic carbene begins exchanging with deuterated acetonitrile when the sample is dissolved for NMR analysis. EA: Found: $\mathrm{C} 43.88, \mathrm{H} 3.74, \mathrm{~N} 11.10$. Calc. for $\mathrm{C}_{33} \mathrm{H}_{31} \mathrm{~F}_{12} \mathrm{~N}_{7} \mathrm{P}_{2} \mathrm{Ru} \cdot\left(\mathrm{CH} \mathrm{CH}_{3} \mathrm{CN}\right)_{0.5}$ : C 43.57, H 3.50, N 11.21\%. ${ }^{1} \mathrm{H}$ NMR (600 MHz; $\left.\mathrm{CD}_{3} \mathrm{CN}\right): \delta=9.10(\mathrm{~m}, 2 \mathrm{H} ; \mathrm{H} 8), 7.92(\mathrm{~m}, 2 \mathrm{H} ; \mathrm{H} 6), 7.52(\mathrm{~m}, 2 \mathrm{H} ; \mathrm{H} 5), 7.50$ (m. 2H; H7), 7.49-7.48 (m, 6H; Ph), 7.39-7.37 (m, 4H; Ph), $5.28(\mathrm{~s}, 4 \mathrm{H} ; \mathrm{H} 3), 2.24(\mathrm{~s}, 6 \mathrm{H} ; \mathrm{H} 10), 1.96(\mathrm{~s}, 3 \mathrm{H} ; \mathrm{H} 12) .{ }^{13} \mathrm{C}\left\{{ }^{1} \mathrm{H}\right\} \mathrm{NMR}: \delta=185.25(\mathrm{C} 1)$, 158.17 (C8), 157.97 (C4), 139.35 (C6), 132.68 (C2), 131.84-128.37 (Ph), 128.13 (C9), 127.01 (C5), 126.04 (C7), 128.35 (C11 (overlaps with $\left.\mathrm{CD}_{3} \mathrm{CN}\right)$ ), $52.18(\mathrm{C} 3), 4.61(\mathrm{C} 10), 1.77\left(\mathrm{C} 12\right.$, overlaps with $\left.\mathrm{CD}_{3} \mathrm{CN}\right)$ ).

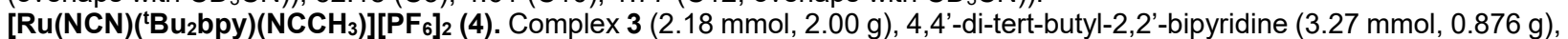
and a Teflon coated stir bar were added to a Schlenk flask and placed under an inert atmosphere. Acetone $(15 \mathrm{~mL}) \mathrm{was}$ added and the solution was refluxed for 2 hours, after which the dark orange solution was cooled to room temperature. In air, diethyl ether $(80 \mathrm{~mL})$ was added to the solution and a bright orange precipitate formed. This was stirred vigorously for a few hours until it became a fine orange powder. The solid was isolated on a medium-pore glass frit, washed with diethyl ether (20 mL), and dried under high vacuum $(2.14 \mathrm{~g}, 89 \%)$. The product is air and moisture stable. EA: Found: C 51.16, H 5.22, N 8.97. Calc. for $\mathrm{C}_{47} \mathrm{H}_{49} \mathrm{~F}_{12} \mathrm{~N}_{7} \mathrm{P}_{2} \mathrm{Ru} \cdot(\mathrm{C} 4 \mathrm{H} 100)_{0.5}$ : C 51.63, $\mathrm{H} 4.77, \mathrm{~N} 8.60 \%$. ${ }^{1} \mathrm{H}$ NMR $\left(600 \mathrm{MHz} ; \mathrm{CD}_{3} \mathrm{CN}\right): \delta=9.44\left(\mathrm{~d},{ }^{3} \mathrm{~J}(\mathrm{H}, \mathrm{H})=5.7 \mathrm{~Hz}, 1 \mathrm{H}\right.$; $\mathrm{H} 18), 8.56\left(\mathrm{~d},{ }^{4} \mathrm{~J}(\mathrm{H}, \mathrm{H})=1.8 \mathrm{~Hz}, 1 \mathrm{H} ; \mathrm{H} 15\right), 8.36\left(\mathrm{~d},{ }^{4} \mathrm{~J}(\mathrm{H}, \mathrm{H})=2.0 \mathrm{~Hz}, 1 \mathrm{H} ; \mathrm{H} 12\right), 8.15\left(\mathrm{~d},{ }^{3} \mathrm{~J}(\mathrm{H}, \mathrm{H})=6.1 \mathrm{~Hz}, 1 \mathrm{H} ; \mathrm{H} 9\right), 8.03(\mathrm{~m}$, $1 \mathrm{H} ; \mathrm{H} 17), 7.69(\mathrm{~m}, 2 \mathrm{H} ; \mathrm{H} 6), 7.66(\mathrm{br}, 2 \mathrm{H} ; \mathrm{H} 8), 7.55-7.48(\mathrm{~m}, 10 \mathrm{H} ; \mathrm{Ph}), 7.40\left(\mathrm{~d},{ }^{3} \mathrm{~J}(\mathrm{H}, \mathrm{H})=7.0 \mathrm{~Hz}, 2 \mathrm{H} ; \mathrm{H} 5\right), 7.25(\mathrm{dd}, 3 \mathrm{~J}(\mathrm{H}, \mathrm{H})=$ $\left.6.1 \mathrm{~Hz},{ }^{4} \mathrm{~J}(\mathrm{H}, \mathrm{H})=2.1 \mathrm{~Hz}, 1 \mathrm{H} ; \mathrm{H} 10\right), 7.02(\mathrm{~m}, 2 \mathrm{H} ; \mathrm{H} 7), 5.31\left(\mathrm{~d},{ }^{2} \mathrm{~J}(\mathrm{H}, \mathrm{H})=16.2 \mathrm{~Hz}, 2 \mathrm{H} ; 3 \mathrm{H}_{\mathrm{a}}\right), 5.14\left(\mathrm{~d},{ }^{2} \mathrm{~J}(\mathrm{H}, \mathrm{H})=16.2 \mathrm{~Hz}, 2 \mathrm{H}\right.$; 
$3 \mathrm{H}_{\mathrm{b}}$ ), 2.38 (s, 3H; H24), 1.57 (s, 9H; H22) 1.36 (s, 9H; H20). ${ }^{13} \mathrm{C}\left\{{ }^{1} \mathrm{H}\right\}$ NMR: $\delta=189.94(\mathrm{C} 1), 164.56$ (C16), 163.41 (C11), 159.35 (C13), 158.58 (C4), 156.79 (C14), 155.72 (C9), 155.61 (C8), 151.83 (C18), 138.89 (C6), 133.06 (C2), 131.94 (Ph), 130.58 (C23), 130.34-128.59 (Ph), 127.01 (C5), 126.12 (C17), 125.80 (C7), 124.55 (C10), 122.81 (C12), 122.27 (C15), 52.14 (C3), 36.59 (C21), 36.14 (C19), 30.65 (C22), 30.39 (C20), 5.14 (C24).

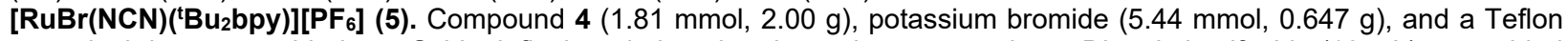
coated stir bar were added to a Schlenk flask and placed under an inert atmosphere. Dimethyl sulfoxide $(10 \mathrm{~mL})$ was added and the deep orange solution was heated at $110^{\circ} \mathrm{C}$ for 2 hours.

In air, the solvent was removed by vacuum distillation at $100{ }^{\circ} \mathrm{C}$. The deep red-orange residue was washed with dichloromethane $(10 \mathrm{~mL})$ and dried with heat and high vacuum to remove more dimethyl sulfoxide. The solid was redissolved in acetonitrile $(50 \mathrm{~mL})$ and the salts were filtered off with a medium pore glass frit. The salts were washed with acetonitrile until the outgoing liquid was colourless. The deep red-orange solution was concentrated, passed through a short path alumina column (acetonitrile), and the leading red-orange fraction was collected. After solvent removal, the residue was redissolved in about $15 \mathrm{~mL}$ acetonitrile and precipitated by adding diethyl ether $(500 \mathrm{~mL})$ while vigorously stirring to afford a red-orange powder. The product was isolated on a medium-pore glass frit and dried under high vacuum (1.61 $\mathrm{g}, 89 \%)$. The product is air and moisture stable. EA: Found: $\mathrm{C} 54.58, \mathrm{H} 5.15, \mathrm{~N}$ 8.39. Calc. for $\mathrm{C}_{45} \mathrm{H}_{46} \mathrm{BrF}_{6} \mathrm{~N}_{6} \mathrm{PRu} \cdot\left(\mathrm{C}_{4} \mathrm{H}_{10} \mathrm{O}\right)_{0.5}: \mathrm{C} 54.60, \mathrm{H} 4.97, \mathrm{~N} 8.13 \%$. ${ }^{1} \mathrm{H}$ NMR $(600 \mathrm{MHz} ; \mathrm{CD} 3 \mathrm{CN}): \delta=10.18\left(\mathrm{~d},{ }^{3} \mathrm{~J}(\mathrm{H}, \mathrm{H})=5.8 \mathrm{~Hz}, 1 \mathrm{H} ; \mathrm{H} 18\right), 8.49\left(\mathrm{~d},{ }^{4} \mathrm{~J}(\mathrm{H}, \mathrm{H})=1.9 \mathrm{~Hz}, 1 \mathrm{H} ; \mathrm{H} 15\right), 8.28\left(\mathrm{~d},{ }^{4} \mathrm{~J}(\mathrm{H}, \mathrm{H})=\right.$ $2.1 \mathrm{~Hz}, 1 \mathrm{H} ; \mathrm{H} 12), 8.14\left(\mathrm{~d},{ }^{3} \mathrm{~J}(\mathrm{H}, \mathrm{H})=6.2 \mathrm{~Hz}, 1 \mathrm{H} ; \mathrm{H} 9\right), 8.03\left(\mathrm{dd},{ }^{3} \mathrm{~J}(\mathrm{H}, \mathrm{H})=5.8 \mathrm{~Hz},{ }^{4} \mathrm{~J}(\mathrm{H}, \mathrm{H})=2.0 \mathrm{~Hz}, 1 \mathrm{H} ; \mathrm{H} 17\right), 7.76(\mathrm{br}, 2 \mathrm{H} ; \mathrm{H} 8)$, $7.54(\mathrm{~m}, 2 \mathrm{H} ; \mathrm{H6}), 7.51-7.45(\mathrm{~m}, 10 \mathrm{H} ; \mathrm{Ph}), 7.26\left(\mathrm{~d},{ }^{3} \mathrm{~J}(\mathrm{H}, \mathrm{H})=7.0 \mathrm{~Hz}, 2 \mathrm{H} ; \mathrm{H} 5\right), 7.10\left(\mathrm{ddd},{ }^{3} \mathrm{~J}(\mathrm{H}, \mathrm{H})=6.2 \mathrm{~Hz}, 4 \mathrm{~J}(\mathrm{H}, \mathrm{H})=2.1 \mathrm{~Hz}\right.$, $1 \mathrm{H} ; \mathrm{H} 10), 6.87(\mathrm{~m}, 2 \mathrm{H} ; \mathrm{H} 7), 5.69\left(\mathrm{br} \mathrm{d}, 2 \mathrm{H} ; 3 \mathrm{H}_{\mathrm{a}}\right), 5.07\left(\mathrm{~d},{ }^{2} \mathrm{~J}(\mathrm{H}, \mathrm{H})=15.6 \mathrm{~Hz}, 2 \mathrm{H} ; 3 \mathrm{H}_{\mathrm{b}}\right), 1.55(\mathrm{~s}, 9 \mathrm{H} ; \mathrm{H} 22) 1.33(\mathrm{~s}, 9 \mathrm{H} ; \mathrm{H} 20) .{ }^{13} \mathrm{C}$ $\left\{{ }^{1} \mathrm{H}\right\}$ NMR: $\delta=195.50(\mathrm{C} 1), 163.17$ (C16), 161.21 (C11), 160.57 (C13), 159.45 (C4), 157.22 (C14), 156.67 (C8), 156.42 (C9), 152.57 (C18), 137.57 (C6), 132.63 (C2), 131.87-129.01 (Ph), 125.99 (C5), 125.70 (C17), 124.78 (C7), 123.92 (C10), 122.44 (C12), 121.33 (C15), 52.48 (C3), 36.40 (C21), 35.89 (C19), $30.73(\mathrm{C} 22), 30.41$ (C20). UV/Vis $\left(\mathrm{CH}_{3} \mathrm{CN}\right): \lambda_{\max }\left(\varepsilon, \mathrm{M}^{-1} \mathrm{~cm}^{-1}\right)=444$ (7000), 352 (10000).

$\mathbf{R u}\left(\mathbf{O}^{\mathrm{t}} \mathrm{Bu}\right)\left(\mathbf{N C N}^{*}\right)$ ('Bu $\mathrm{Bu}_{2}$ bpy) (6). Compound $5(0.10 \mathrm{mmol}, 100 \mathrm{mg})$ and $\mathrm{KO}$ 'Bu $(0.22 \mathrm{mmol}, 25 \mathrm{mg})$, and a Teflon coated stir bar are combined in a vial inside an argon-filled glove box. Tetrahydrofuran $(2 \mathrm{~mL})$ was added and the solution immediately turned deep maroon-orange and was stirred for 2 hours at room temperature. After 2 hours, the deep maroon-purple solution was dried under high vacuum and redissolved in toluene $(2 \mathrm{~mL})$. The solution was filtered through a pad of Celite and dried. Trituration with pentane and drying under high vacuum afforded deep maroon-purple solid 6 (80 mg, 95\%). Crystallization by slow vapour diffusion of pentane into a concentrated toluene solution yields deep purple-black crystals (71\%), which were suitable for X-ray diffraction. Compound $\mathbf{6}$ is freely soluble in toluene, tetrahydrofuran, diethyl ether, and partly soluble in pentane. Due to the highly sensitive nature of 6, a powder or crystalline sample did not yield satisfactory elemental analysis data after several attempts, despite being pure by NMR spectroscopy. ${ }^{1} \mathrm{H}$ NMR $\left(600 \mathrm{MHz} ; \mathrm{THF}-d_{8}, 0{ }^{\circ} \mathrm{C}\right): \delta=10.13\left(\mathrm{~d},{ }^{3} \mathrm{~J}(\mathrm{H}, \mathrm{H})\right.$ $=5.8 \mathrm{~Hz}, 1 \mathrm{H} ; \mathrm{H} 18), 8.34\left(\mathrm{~d},{ }^{3} \mathrm{~J}(\mathrm{H}, \mathrm{H})=6.3 \mathrm{~Hz}, 1 \mathrm{H} ; \mathrm{H} 9\right), 8.29(\mathrm{~d}, 1 \mathrm{H} ; \mathrm{H} 15), 8.09(\mathrm{~d}, 1 \mathrm{H} ; \mathrm{H} 12), 7.73\left(\mathrm{dd},{ }^{3} \mathrm{~J}(\mathrm{H}, \mathrm{H})=5.8 \mathrm{~Hz}, 1 \mathrm{H}\right.$; $\mathrm{H} 17)$, 7.41-7.33 (m, 6H; Ph), 7.32 (m, 1H; H6), 7.28-7.25 (m, 4H; Ph), $7.16(\mathrm{~m}, 1 \mathrm{H} ; \mathrm{H} 5), 7.00\left(\mathrm{~d},{ }^{3} \mathrm{~J}(\mathrm{H}, \mathrm{H})=5.7 \mathrm{~Hz}, 1 \mathrm{H} ; \mathrm{H} 8\right)$, $6.77\left(\mathrm{dd},{ }^{3} \mathrm{~J}(\mathrm{H}, \mathrm{H})=6.3 \mathrm{~Hz}, 1 \mathrm{H} ; \mathrm{H} 10\right), 6.50(\mathrm{~m}, 1 \mathrm{H} ; \mathrm{H} 7), 6.47\left(\mathrm{~d},{ }^{2} \mathrm{~J}(\mathrm{H}, \mathrm{H})=13.2 \mathrm{~Hz}, 2 \mathrm{H} ; 3 \mathrm{H}_{\mathrm{a}}\right), 5.89\left(\mathrm{~d},{ }^{3} \mathrm{~J}(\mathrm{H}, \mathrm{H})=6.4 \mathrm{~Hz}, 1 \mathrm{H}\right.$; $\mathrm{H} 23), 5.55(\mathrm{~m}, 1 \mathrm{H} ; \mathrm{H} 25), 5.06(\mathrm{~s}, 1 \mathrm{H} ; \mathrm{H} 28), 5.04\left(\mathrm{~d},{ }^{3} \mathrm{~J}(\mathrm{H}, \mathrm{H})=8.8 \mathrm{~Hz}, 1 \mathrm{H} ; \mathrm{H} 26\right), 4.74\left(\mathrm{~d},{ }^{2} \mathrm{~J}(\mathrm{H}, \mathrm{H})=13.2 \mathrm{~Hz}, 2 \mathrm{H} ; 3 \mathrm{H}_{\mathrm{b}}\right), 4.20(\mathrm{~m}$, $1 \mathrm{H} ; \mathrm{H} 24), 1.52$ (s, 9H; H22) 1.29 (s, 9H; H20), 0.99 (s, 9H; H31). ${ }^{13} \mathrm{C}\left\{{ }^{1} \mathrm{H}\right\}$ NMR: $\delta=190.74(\mathrm{C} 1), 162.00$ (C4), 160.18 (C13), 158.22 (C16), 156.77 (C14), 154.39 (C9), 153.33 (C11), 153.28 (C8), 152.03 (C23), 150.32 (C18), 145.72 (C27), 133.80 (C6), 131.68-130.63 (Ph), $130.36(\mathrm{C} 2), 129.13-127.69(\mathrm{Ph}), 125.87$ (C29), $125.81(\mathrm{C} 25), 123.41(\mathrm{C} 5), 122.54(\mathrm{C} 7), 121.90(\mathrm{C} 17)$, 121.15 (C10), 119.88 (C12), 117.93 (C15), 114.79 (C26), 98.48 (C24), 86.99 (C28), 71.36 (C30), 51.22 (C3), 35.70 (C21), 35.04 (C31), 34.97 (C19), 30.81 (C22), 30.40 (C20). UV/Vis (THF): $\lambda \max \left(\varepsilon, \mathrm{M}^{-1} \mathrm{~cm}^{-1}\right)=487(7000), 378(10000)$.

Ru(NCN $\left.{ }^{* *}\right)\left(\mathrm{PPh}_{3}\right)\left({ }^{\mathrm{t}} \mathrm{Bu}_{2}\right.$ bpy) (8). Compound 6 (0.040 mmol, $\left.\left.40 \mathrm{mg}\right), \mathrm{PPh}_{3},(0.040 \mathrm{mmol}, 11 \mathrm{mg}), \mathrm{KO}{ }^{\mathrm{B}} \mathrm{Bu}(0.12 \mathrm{mmol}), 14 \mathrm{mg}\right)$, and a Teflon coated stir bar are combined in a vial inside an argon-filled glove box. Tetrahydrofuran ( $3 \mathrm{~mL})$ was added and the solution was stirred overnight at room temperature. The deep red-orange solution was dried under high vacuum and redissolved in toluene $(3 \mathrm{~mL})$, then filtered through a pad of Celite and dried. The solid was washed and suspended by vigorously stirring with hexane $(3 \mathrm{~mL})$, collected on a medium-pore glass frit, and dried under high vacuum (30 mg, $73 \%)$. Crystals suitable for X-ray diffraction were grown by slow vapour diffusion of pentane into a concentrated toluene solution. Formation of 8 is also observed by ${ }^{1} \mathrm{H}$ NMR if one equivalent $\mathrm{PPh}_{3}$ is added to 6 in a vigorously stirred THF solution in an argon-filled glove box. EA: Found: $\mathrm{C} 72.96, \mathrm{H} 6.04, \mathrm{~N} 7.80$. Calc. for $\mathrm{C}_{63} \mathrm{H}_{59} \mathrm{~N}_{6} \mathrm{PRu}$ : C 73.31, H 5.76, N 8.14\%. ${ }^{1} \mathrm{H}$ NMR $(500$ $\mathrm{MHz}$; THF- $\left.d_{8}, 25{ }^{\circ} \mathrm{C}\right): \delta=9.11\left({ }^{3} \mathrm{~J}(\mathrm{H}, \mathrm{H})=5.9 \mathrm{~Hz}, 1 \mathrm{H} ; \mathrm{H} 18\right), 8.69\left(\mathrm{dd},{ }^{3} \mathrm{~J}(\mathrm{H}, \mathrm{H})=5.9 \mathrm{~Hz},{ }^{4} \mathrm{~J}(\mathrm{H}, \mathrm{H})=2.9 \mathrm{~Hz} 1 \mathrm{H} ; \mathrm{H} 9\right), 8.30(\mathrm{~d}$, $\left.{ }^{4} \mathrm{~J}(\mathrm{H}, \mathrm{H})=2.0 \mathrm{~Hz}, 1 \mathrm{H} ; \mathrm{H} 15\right), 8.27(\mathrm{~m}, 1 \mathrm{H} ; \mathrm{H} 12), 7.72-7.69(\mathrm{~m}, 6 \mathrm{H} ; \mathrm{Ph}), 7.48(\mathrm{~m}, 1 \mathrm{H} ; \mathrm{H} 10), 7.31\left(\mathrm{dd},{ }^{3} \mathrm{~J}(\mathrm{H}, \mathrm{H})=5.9 \mathrm{~Hz},{ }^{4} \mathrm{~J}(\mathrm{H}, \mathrm{H})\right.$ $=2.0 \mathrm{~Hz}, 1 \mathrm{H} ; \mathrm{H} 17), 7.22-7.09(\mathrm{~m}, 19 \mathrm{H} ; \mathrm{Ph}), 5.50(\mathrm{~m}, 2 \mathrm{H} ; \mathrm{H} 6), 4.97(\mathrm{~m}, 2 \mathrm{H} ; \mathrm{H} 8), 4.79(\mathrm{~m}, 2 \mathrm{H} ; \mathrm{H} 5), 4.53(\mathrm{~s}, 2 \mathrm{H} ; \mathrm{H} 3), 4.08(\mathrm{~m}$, $2 \mathrm{H} ; \mathrm{H} 7), 1.41(\mathrm{~s}, 9 \mathrm{H} ; \mathrm{H} 20), 1.39(\mathrm{~s}, 9 \mathrm{H} ; \mathrm{H} 22) .{ }^{13} \mathrm{C}\left\{{ }^{1} \mathrm{H}\right\}$ NMR: $\left.\delta=174.19\left(\mathrm{~d},{ }^{2} \mathrm{~J}(\mathrm{C}, \mathrm{P})=17.9 \mathrm{~Hz}\right) ; \mathrm{C} 1\right), 160.38(\mathrm{C} 11), 160.37$ (C16), 158.33 (C14), 157.35 (C13), 154.18 (C18), 153.05 (C9), 150.91 (C8), 147.78 (C4), 139.67-127.16 (Ph), 126.23 (C6), 125.59 (C2), 123.33 (C17), 123.20 (C10), 120.60 (C15), 119.21 (C12), 115.15 (C5), 99.89 (C7), 88.06 (C3), 35.67 (C21), 35.59 (C19), 30.46 (C20), $30.35(\mathrm{C} 22) .{ }^{31} \mathrm{P}\left\{{ }^{1} \mathrm{H}\right\}$ NMR: $\delta=57.69(\mathrm{~s})$

$\mathrm{Ru}(\mathrm{OH})\left(\mathrm{NCN}^{*}\right)\left({ }^{\mathrm{t}} \mathrm{Bu}_{2} \mathrm{bpy}\right)(\mathbf{9})$. Compound $6(0.019 \mathrm{mmol}, 16 \mathrm{mg})$ was placed into an NMR tube and then dissolved in THF- $d_{8}$. The tube was sealed with a tight fitting rubber septum, which was then wrapped with Parafilm-M. The NMR tube was removed from the glove box and distilled/degassed $\mathrm{H}_{2} \mathrm{O}(0.50 \mu \mathrm{L}, 0.028 \mathrm{mmol})$ was injected with a microsyringe. Shaking the tube for a few seconds allowed the droplet deposited at the top to dissolve into the solution below. The solution was heated at $40{ }^{\circ} \mathrm{C}$ for 5 minutes, changing from deep maroon-purple to deep maroon-orange in color and was immediately analyzed by NMR spectroscopy $\left(0^{\circ} \mathrm{C}\right)$. The same procedure was used when reacted with $\mathrm{D}_{2} \mathrm{O}(0.50 \mu \mathrm{L}, 0.025 \mathrm{mmol})$. ${ }^{1} \mathrm{H} \mathrm{NMR}(600 \mathrm{MHz}$; THF$\left.d_{8}, 0^{\circ} \mathrm{C}\right): \delta=9.87\left(\mathrm{~d},{ }^{3} \mathrm{~J}(\mathrm{H}, \mathrm{H})=5.8 \mathrm{~Hz}, 1 \mathrm{H} ; \mathrm{H} 18\right), 8.32(\mathrm{~m}, 1 \mathrm{H} ; \mathrm{H} 9), 8.27\left(\mathrm{~d},{ }^{3} \mathrm{~J}(\mathrm{H}, \mathrm{H})=6.2 \mathrm{~Hz}, 1 \mathrm{H} ; \mathrm{H} 15\right), 8.09(\mathrm{~m}, 1 \mathrm{H} ; \mathrm{H} 12)$, $7.69(\mathrm{~m}, 1 \mathrm{H} ; \mathrm{H} 17), 7.40-7.26(\mathrm{~m}, 10 \mathrm{H} ; \mathrm{Ph}), 7.32(\mathrm{~m}, 1 \mathrm{H} ; \mathrm{H} 6), 7.22(\mathrm{~m}, 1 \mathrm{H} ; \mathrm{H} 5), 6.80(\mathrm{~m}, 1 \mathrm{H} ; \mathrm{H} 8), 6.73(\mathrm{~m}, 1 \mathrm{H} ; \mathrm{H} 10), 6.49(\mathrm{~m}$, $1 \mathrm{H} ; \mathrm{H} 7), 6.41\left(\mathrm{~d},{ }^{2} \mathrm{~J}(\mathrm{H}, \mathrm{H})=14 \mathrm{~Hz},{ }^{2} \mathrm{H} ; 3 \mathrm{H}_{\mathrm{a}}\right), 6.09\left(\mathrm{~d},{ }^{3} \mathrm{~J}(\mathrm{H}, \mathrm{H})=6.3 \mathrm{~Hz}, 1 \mathrm{H} ; \mathrm{H} 23\right), 5.62(\mathrm{~m}, 1 \mathrm{H} ; \mathrm{H} 25), 5.15\left(\mathrm{~d},{ }^{3} \mathrm{~J}(\mathrm{H}, \mathrm{H})=8.9 \mathrm{~Hz}\right.$, 
$1 \mathrm{H} ; \mathrm{H} 26), 5.02(\mathrm{~s}, 1 \mathrm{H} ; \mathrm{H} 28), 4.92\left(\mathrm{~d},{ }^{2} \mathrm{~J}(\mathrm{H}, \mathrm{H})=14 \mathrm{~Hz}, 2 \mathrm{H} ; 3 \mathrm{H}_{\mathrm{b}}\right), 4.36(\mathrm{~m}, 1 \mathrm{H} ; \mathrm{H} 24), 3.33\left(\mathrm{br}, \mathrm{H}_{2} \mathrm{O}+\left(\mathrm{CH}_{3}\right)_{3} \mathrm{COH}\right), 1.51(\mathrm{~s}, 9 \mathrm{H}$; H22) 1.29 (s, 9H; H20), $1.07\left(\mathrm{~s}, 9 \mathrm{H} ;\left(\mathrm{CH}_{3}\right)_{3} \mathrm{COH}\right),-2.35$ (br, $\left.1 \mathrm{H} ; \mathrm{H} 30\right) .{ }^{13} \mathrm{C}\left\{{ }^{1} \mathrm{H}\right\} \mathrm{NMR}: \delta=188.41$ (C1), $162.86(\mathrm{C} 4), 159.31$ (C13), 157.70 (C16), 156.67 (C14), 154.59 (C9), 153.61 (C11), 153.56 (C8), 150.51 (C23), 150.37 (C18), 146.21 (C27), 133.63 (C6), 131.37-130.52 (Ph), 130.19 (C2), 129.19-127.92 (Ph), 126.11 (C29), 125.99 (C25), 124.06 (C5), 122.94 (C7), 122.18 (C17), 120.78 (C10), 119.80 (C12), 118.20 (C15), 114.29 (C26), 99.37 (C24), 87.63 (C28), 66.72 ((CH3)3COH), 51.38 (C3), 35.67 (C21), 35.00 (C19), $31.80((\mathrm{CH} 3) 3 \mathrm{COH}), 30.78$ (C22), $30.41(\mathrm{C} 20)$.

\section{Acknowledgements}

The authors wish to acknowledge the Canadian Foundation of Innovation, project number 19119, and the Ontario Research Fund for funding of the Centre for Spectroscopic Investigation of Complex Organic Molecules and Polymers. R. H. M. thanks the Natural Sciences and Engineering Research Council (NSERC) for a Discovery grant and D. E. P. thanks NSERC for scholarship funding.

Keywords: carbene complex $\cdot \mathrm{C}-\mathrm{H}$ bond activation $\bullet$ water splitting $\bullet$ DNMR $\bullet$ density functional theory

\section{References}

[1] a) B. Askevold, H. W. Roesky, S. Schneider, ChemCatChem 2012, 4, 307-320; b) D. Gelman, S. Musa, ACS Catal. 2012, 2, 2456-2466; c) J. I. van der Vlugt, Eur. J. Inorg. Chem. 2012, 2012, 363-375; d) V. T. Annibale, D. Song, RSC Adv. 2013, 3, 11432-11449; e) D. V. Gutsulyak, W. E. Piers, J. Borau-Garcia, M. Parvez, J. Am. Chem. Soc. 2013, 135, 11776-11779; f) R. E. Rodríguez-Lugo, M. Trincado, M. Vogt, F. Tewes, G. Santiso-Quinones, H. Grützmacher, Nat. Chem. 2013, 5, 342-347.

[2] a) D. Milstein, Top. Catal. 2010, 53, 915-923; b) E. Balaraman, C. Gunanathan, J. Zhang, L. J. W. Shimon, D. Milstein, Nat. Chem. 2011, 3, 609-614; c) C. Gunanathan, D. Milstein, Acc. Chem. Res. 2011, 44, 588-602; d) E. Balaraman, E. Khaskin, G. Leitus, D. Milstein, Nat. Chem. 2013, 5, 122-125; e) C. Gunanathan, D. Milstein, Science 2013, 341.

[3] a) F. Hasanayn, A. Baroudi, A. A. Bengali, A. S. Goldman, Organometallics 2013, 32, 6969-6985; b) H. Li, M. B. Hall, J. Am. Chem. Soc. 2014, 136, 383-395; c) H. Li, X. Wang, F. Huang, G. Lu, J. Jiang, Z.-X. Wang, Organometallics 2011, 30, 5233-5247; d) H. Li, M. Wen, Z. X. Wang, Inorg. Chem. 2012, 51, 5716-5727; e) J. Li, Y. Shiota, K. Yoshizawa, J. Am. Chem. Soc. 2009, 131, 13584-13585; f) K. S. Sandhya, C. H. Suresh, Organometallics 2011, 30, 3888-3891; g) X. Yang, Inorg. Chem. 2011, 50, 12836-12843; h) X. Yang, M. B. Hall, J. Am. Chem. Soc. 2010, 132, 120-130; i) C. Gunanathan, Y. Ben-David, D. Milstein, Science 2007, 317, 790-792.

[4] a) C. del Pozo, M. Iglesias, F. Sánchez, Organometallics 2011, 30, 2180-2188; b) E. Fogler, E. Balaraman, Y. Ben-David, G. Leitus, L. J. W. Shimon, D. Milstein, Organometallics 2011, 30, 3826-3833; c) Y. Sun, C. Koehler, R. Tan, V. T. Annibale, D. Song, Chem. Commun. 2011, 47, 8349-8351.

[5] a) W. E. Piers, Organometallics 2011, 30, 13-16; b) R. H. Crabtree, Organometallics 2011, 30, 17-19; c) N. S. Lewis, D. G. Nocera, Proc. Natl. Acad. Sci. U.S.A. 2006, 103, 15729-15735; d) R. Tanaka, M. Yamashita, L. W. Chung, K. Morokuma, K. Nozaki, Organometallics 2011, 30, 6742-6750; e) D. G. H. Hetterscheid, J. I. van der Vlugt, B. de Bruin, J. N. H. Reek, Angew. Chem., Int. Ed. 2009, 48, 8178-8181; f) D. G. Nocera, Acc. Chem. Res. 2012, 45, 767-776; g) K. S. Joya, Y. F. Joya, K. Ocakoglu, R. van de Krol, Angew. Chem., Int. Ed. 2013, 52, 10426-10437; h) Y. Mulyana, F. R. Keene, L. Spiccia, Dalton Trans. 2014, 43, 6819-6827; i) C. L. Pitman, A. J. M. Miller, ACS Catal. 2014, 4, 2727-2733; j) T. Stoll, M. Gennari, J. Fortage, C. E. Castillo, M. Rebarz, M. Sliwa, O. Poizat, F. Odobel, A. Deronzier, M.-N. Collomb, Angew. Chem., Int. Ed. 2014, 53, 1654-1658; k) L. Tong, R. Zong, R. P. Thummel, J. Am. Chem. Soc. 2014, 136, 4881-4884.

[6] a) S. W. Kohl, L. Weiner, L. Schwartsburd, L. Konstantinovski, L. J. W. Shimon, Y. Ben-David, M. A. Iron, D. Milstein, Science 2009, 324, 74-77; b) L. Hammarstrom, S. Styring, Nat. Chem. 2009, 1, 185-186; c) R. Eisenberg, Science 2009, 324, 44-45.

[7] a) V. V. Grushin, W. J. Marshall, J. Am. Chem. Soc. 2006, 128, 4632-4641; b) D. E. Prokopchuk, A. Collado, A. J. Lough, R. H. Morris, Dalton Trans. 2013, 42, 10214-10220.

[8] a) J. P. Birk, J. Halpern, A. L. Pickard, J. Am. Chem. Soc. 1968, 90, 4491-4492; b) J. Halpern, A. L. Pickard, Inorg. Chem. 1970, 9, 2798-2800; c) A. Sen, J. Halpern, J. Am. Chem. Soc. 1977, 99, 8337-8339; d) M. W. Kanan, D. G. Nocera, Science 2008, 321, 1072-1075.

[9] W. R. Turner, P. J. Elving, Anal. Chem. 1965, 37, 467-469.

[10] a) J. J. Concepcion, J. W. Jurss, J. L. Templeton, T. J. Meyer, Proc. Natl. Acad. Sci. U.S.A. 2008, 105, 1763217635; b) J. J. Concepcion, J. W. Jurss, M. K. Brennaman, P. G. Hoertz, A. O. T. Patrocinio, N. Y. Murakami Iha, J. L. Templeton, T. J. Meyer, Acc. Chem. Res. 2009, 42, 1954-1965; c) J. J. Concepcion, M.-K. Tsai, J. T. Muckerman, T. J. Meyer, J. Am. Chem. Soc. 2010, 132, 1545-1557; d) X. Liu, F. Wang, Coord. Chem. Rev. 2012, 256, 1115-1136; e) X. Sala, I. Romero, M. Rodríguez, L. Escriche, A. Llobet, Angew. Chem., Int. Ed. 2009, 48, 2842-2852. 
[11] a) M. C. B. Legault, C. S. McKay, J. Moran, M. A. Lafreniere, J. P. Pezacki, Tetrahedron Lett. 2012, 53, 56635666; b) A. G. Tskhovrebov, E. Solari, M. D. Wodrich, R. Scopelliti, K. Severin, Angew. Chem., Int. Ed. 2012, 51, 232-234; c) A. G. Tskhovrebov, B. Vuichoud, E. Solari, R. Scopelliti, K. Severin, J. Am. Chem. Soc. 2013, 135, 9486-9492.

[12] a) B. Liu, Y. Zhang, D. Xu, W. Chen, Chem. Commun. 2011, 47, 2883-2885; b) M. Slivarichova, R. Ahmad, Y.-Y. Kuo, J. Nunn, M. F. Haddow, H. Othman, G. R. Owen, Organometallics 2011, 30, 4779-4787; c) X. Liu, W. Chen, Organometallics 2012, 31, 6614-6622.

[13] M. S. Jeletic, I. Ghiviriga, K. A. Abboud, A. S. Veige, Organometallics 2007, 26, 5267-5270.

[14] a) A. M. Magill, D. S. McGuinness, K. J. Cavell, G. J. P. Britovsek, V. C. Gibson, A. J. P. White, D. J. Williams, A. H. White, B. W. Skelton, J. Organomet. Chem. 2001, 617-618, 546-560; b) M. C. Jahnke, T. Pape, F. E. Hahn, Eur. J. Inorg. Chem. 2009, 2009, 1960-1969.

[15] a) V. J. Catalano, M. A. Malwitz, Inorg. Chem. 2003, 42, 5483-5485; b) V. J. Catalano, M. A. Malwitz, A. O. Etogo, Inorg. Chem. 2004, 43, 5714-5724; c) V. J. Catalano, A. L. Moore, Inorg. Chem. 2005, 44, 6558-6566.

[16] CCDC 1001662 (1) and CCDC 1001663 (3) contain the supplementary crystallographic data for these compounds. This data can be obtained free of charge from the Cambridge Crystallographic Data Centre via www.ccdc.cam.ac.uk/data_request/cif.

[17] CCDC 1001664 (6) contains the supplementary crystallographic data. This data can be obtained free of charge from the Cambridge Crystallographic Data Centre via www.ccdc.cam.ac.uk/data request/cif.

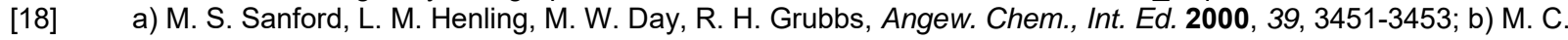
Maclnnis, R. McDonald, M. J. Ferguson, S. Tobisch, L. Turculet, J. Am. Chem. Soc. 2011, 133, 13622-13633; c) M. C. Lipke, T. D. Tilley, J. Am. Chem. Soc. 2013, 135, 10298-10301.

[19] We were unable to observe any peak coalescence at elevated temperatures due to product loss above $70 \mathrm{C}$ in toluene-d8.

[20] CCDC 1015163 (8) contains the supplementary crystallographic data. This data can be obtained free of charge from the Cambridge Crystallographic Data Centre via www.ccdc.cam.ac.uk/data_request/cif.

[21] a) C. Tejel, M. P. del Río, M. A. Ciriano, E. J. Reijerse, F. Hartl, S. Záliš, D. G. H. Hetterscheid, N. Tsichlis i Spithas, B. de Bruin, Chem. Eur. J. 2009, 15, 11878-11889; b) P. O. Lagaditis, A. J. Lough, R. H. Morris, J. Am. Chem. Soc. 2011, 133, 9662-9665; c) C. Tejel, M. P. del Río, L. Asensio, F. J. van den Bruele, M. A. Ciriano, N. Tsichlis i Spithas, D. G. H. Hetterscheid, B. de Bruin, Inorg. Chem. 2011, 50, 7524-7534; d) S. Schneider, J. Meiners, B. Askevold, Eur. J. Inorg. Chem. 2012, 2012, 412-429; e) G. Zeng, S. Sakaki, K.-i. Fujita, H. Sano, R. Yamaguchi, ACS Catal. 2014, 4, 1010-1020.

[22] T. J. Korstanje, M. Lutz, J. T. B. H. Jastrzebski, R. J. M. Klein Gebbink, Organometallics 2014, 33, $2201-2209$.

[23] C. Hahn, M. Spiegler, E. Herdtweck, R. Taube, Eur. J. Inorg. Chem. 1998, 1998, 1425-1432.

[24] M. Feller, E. Ben-Ari, M. A. Iron, Y. Diskin-Posner, G. Leitus, L. J. W. Shimon, L. Konstantinovski, D. Milstein, Inorg. Chem. 2010, 49, 1615-1625.

[25] M. Vogt, O. Rivada-Wheelaghan, M. A. Iron, G. Leitus, Y. Diskin-Posner, L. J. W. Shimon, Y. Ben-David, D. Milstein, Organometallics 2013, 32, 300-308.

[26] D. S. Stephenson, G. Binsch, Journal of Magnetic Resonance (1969) 1978, 30, 625-626.

[27] K. Marat, Spinworks 4.0.3, University of Manitoba, 2014.

[28] a) P. G. Jessop, R. H. Morris, Coord. Chem. Rev. 1992, 121, 155-284; b) C. L. Perrin, T. J. Dwyer, Chemical Reviews 1990, 90, 935-967.

[29] M. J. Frisch et al., Gaussian 09 Rev. B.01, Gaussian, Inc., Wallingford, CT, 2009. For the full reference, see the Supporting Information.

[30] Y. Zhao, D. G. Truhlar, J. Chem. Phys. 2006, 125, 194101.

[31] A. Schäfer, C. Huber, R. Ahlrichs, J. Chem. Phys. 1994, 100, 5829-5835.

[32] F. Weigend, R. Ahlrichs, Phys. Chem. Chem. Phys. 2005, 7, 3297-3305.

[33] D. G. Gusev, Organometallics 2013, 32, 4239-4243.

[34] M. O. Albers, E. Singleton, J. E. Yates, F. B. McCormick, in Inorganic Syntheses, Vol. 26, John Wiley \& Sons, Inc., 2007, 249-258.

[35] G. R. Fulmer, A. J. M. Miller, N. H. Sherden, H. E. Gottlieb, A. Nudelman, B. M. Stoltz, J. E. Bercaw, K. I. Goldberg, Organometallics 2010, 29, 2176-2179.

[36] S. Berger, S. Braun, Wiley-VCH, 2004, p. 145.

[37] Z. Otwinowski, W. Minor, in Macromolecular Crystallography Part A, Vol. 276, Academic Press, 1997, $307-326$.

[38] G. M. Sheldrick, Acta Crystallogr., Sect. A 2008, 64, 112-122.

[39] J. Tomasi, B. Mennucci, E. Cancès, J. Mol. Struct. THEOCHEM 1999, 464, 211-226.

[40] A. V. Marenich, C. J. Cramer, D. G. Truhlar, J. Phys. Chem. B 2009, 113, 6378-6396.

[41] http://www.chemcraftprog.com.

[42] P. L. Chiu, C.-L. Lai, C.-F. Chang, C.-H. Hu, H. M. Lee, Organometallics 2005, 24, 6169-6178. 


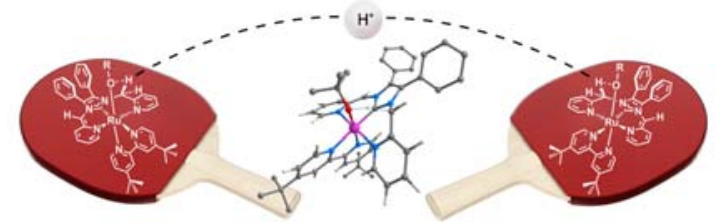

Proton Pincer Ping-Pong: New phosphine-free Ru-NCN pincer complexes have been synthesized. The dearomatized alkoxide/hydroxide analogues undergo unprecedented regioselective, intramolecular $\mathrm{C}-\mathrm{H} / \mathrm{O}-\mathrm{H}$ bond activation with tert-butanol or water at $25^{\circ} \mathrm{C}$, as shown by NMR experiments and DFT calculations. 


\section{Contents}

1 NMR Numbering Scheme, NMR Spectra, and Eyring Plot.

2 X-Ray crystal structure and refinement data.

$\begin{array}{llr}3 & \text { DFT Data } & \text { S28 }\end{array}$

3.1 Cartesian Coordinates $(\AA)$, Free Energies $\left(G^{\circ}\right.$, Hartree), and Enthalpies $\left(H^{\circ}\right.$, Hartree) of Optimized Structures . . . . . . . . . . . . . . . . . . . . S29

3.2 Full Gaussian 09 Reference . . . . . . . . . . . . . . . . . . . . S33 


\section{NMR Numbering Scheme, NMR Spectra, and Eyring Plot.}
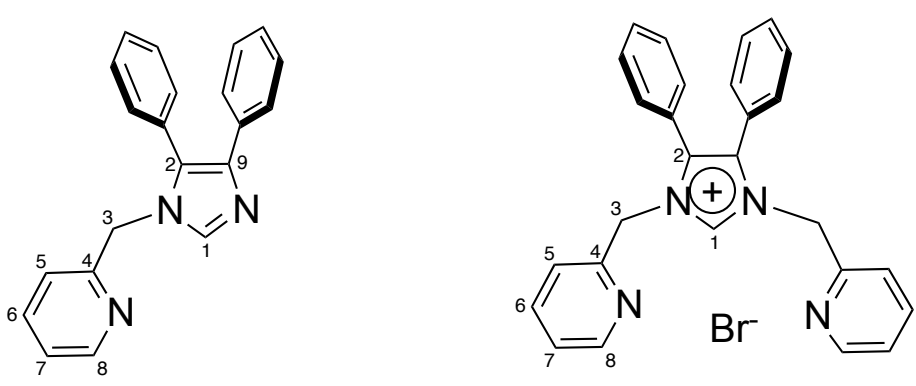

1

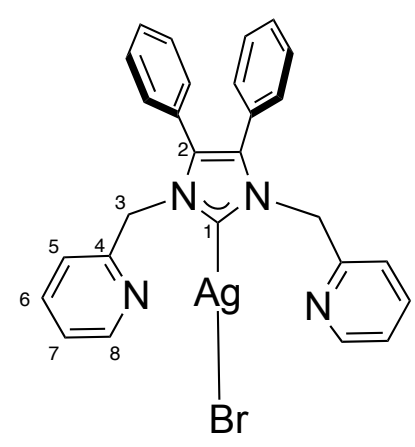

3
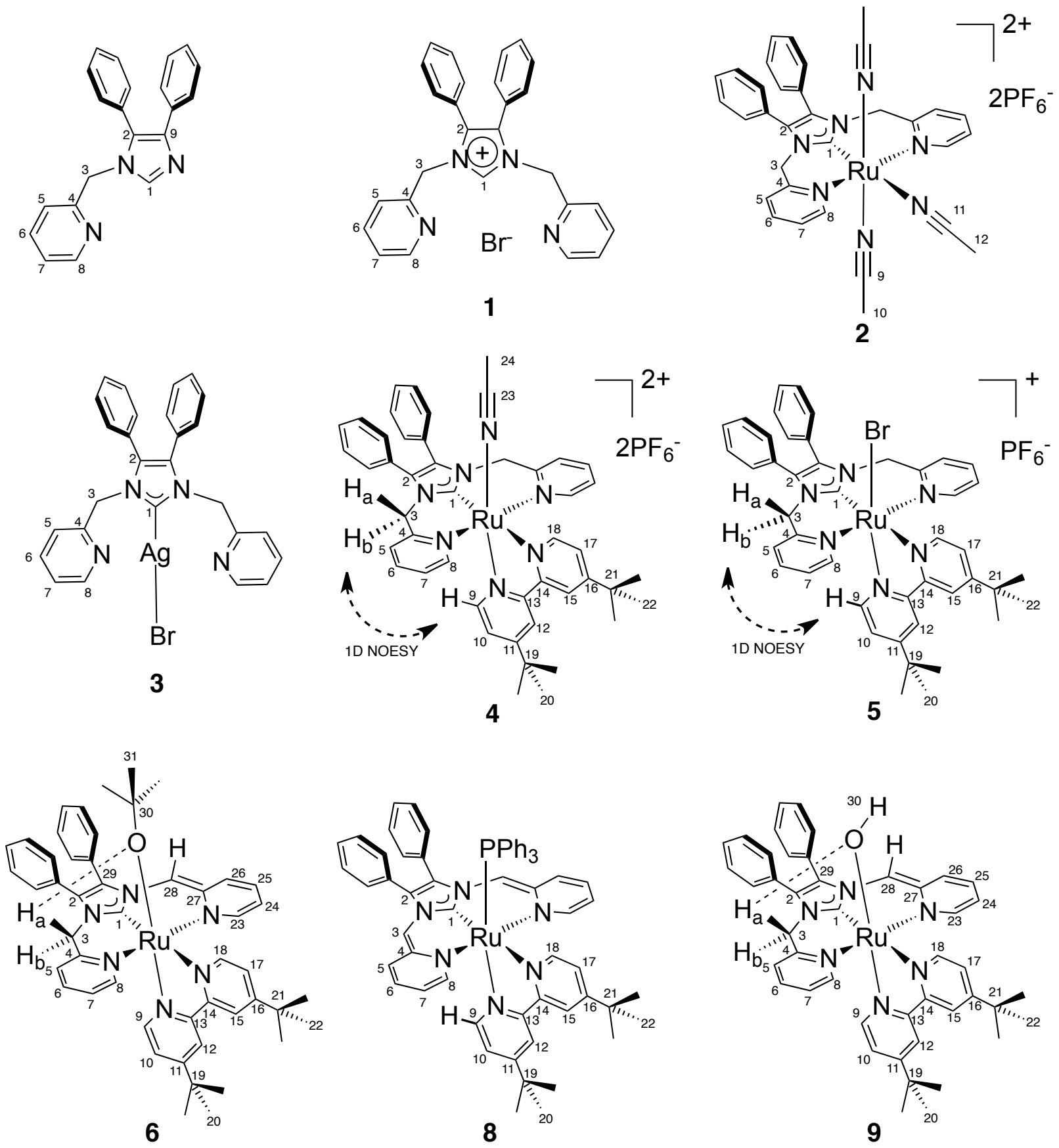


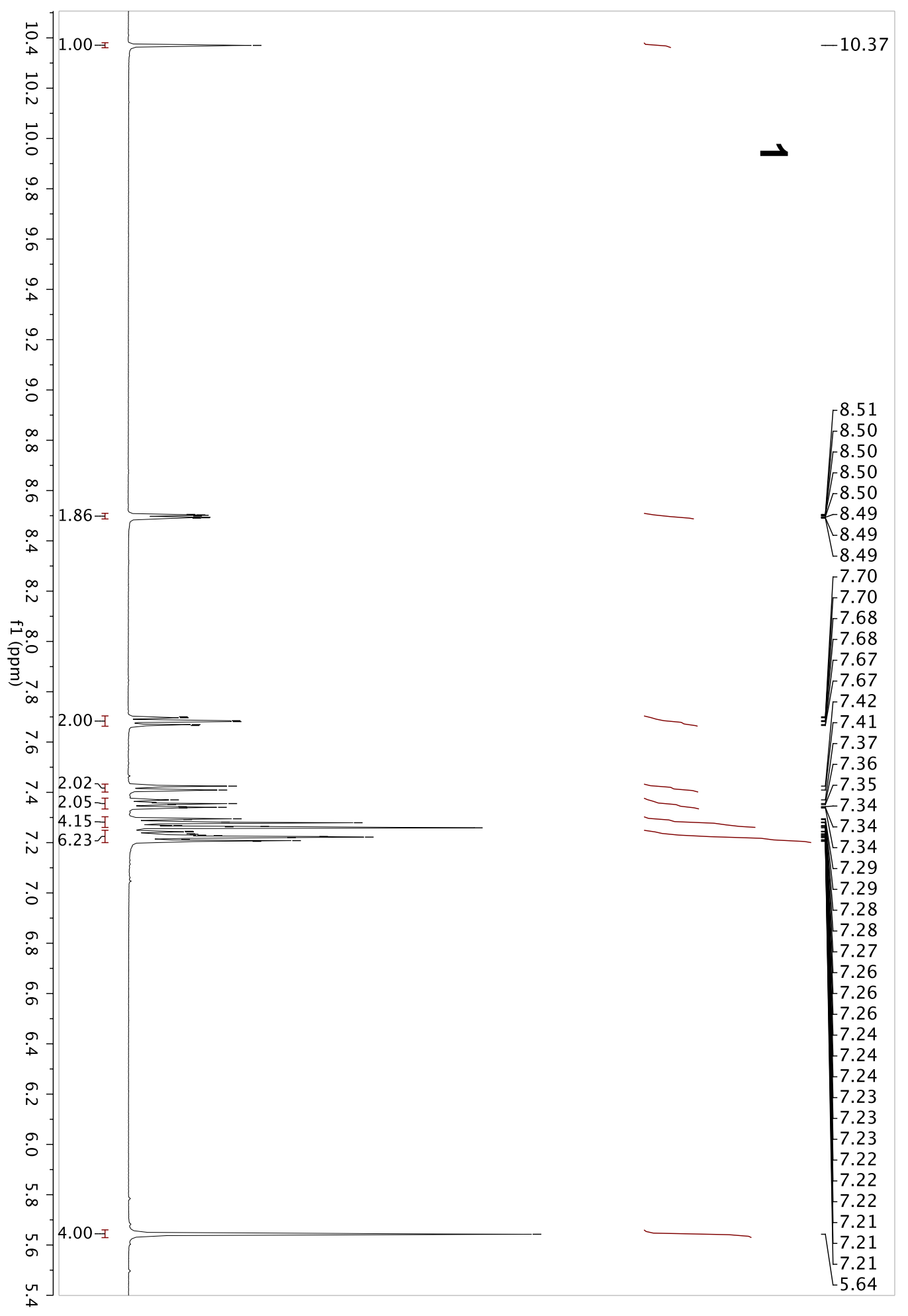

Figure 1: ${ }^{1} \mathrm{H}$ NMR spectrum of $\mathbf{1}$. 


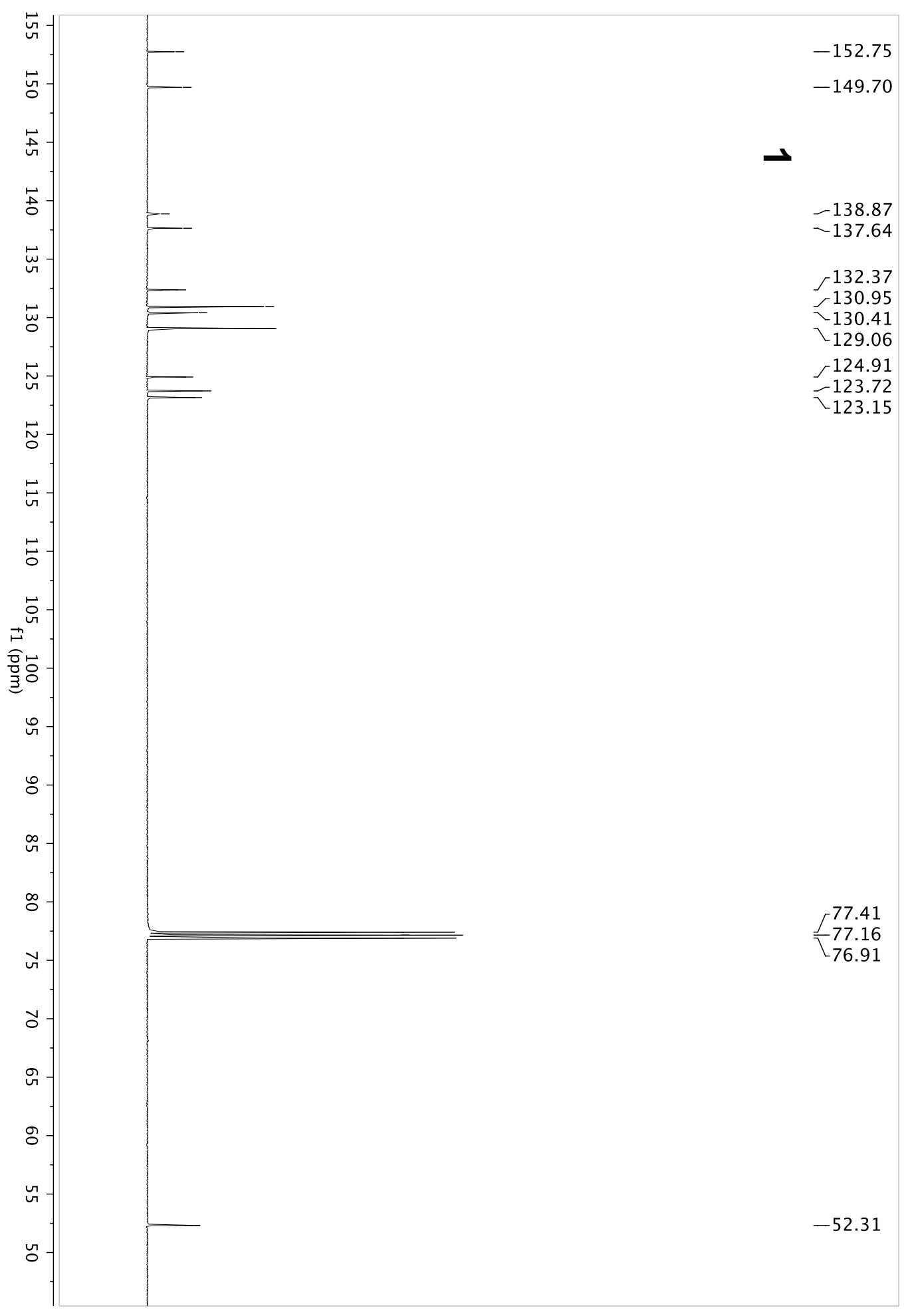

Figure 2: ${ }^{13} \mathrm{C}$ NMR spectrum of $\mathbf{1}$. 


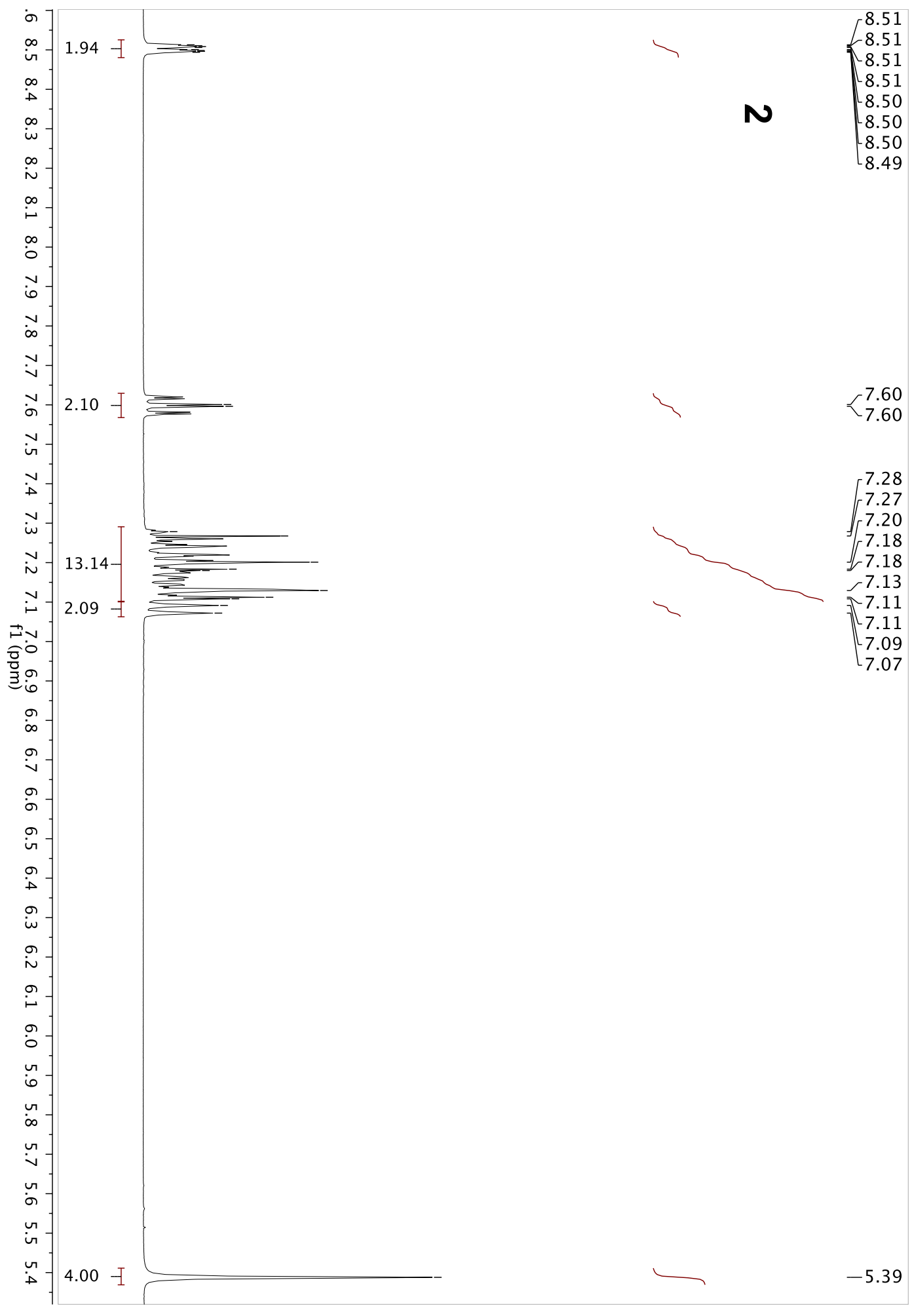

Figure 3: ${ }^{1} \mathrm{H}$ NMR spectrum of 2. 


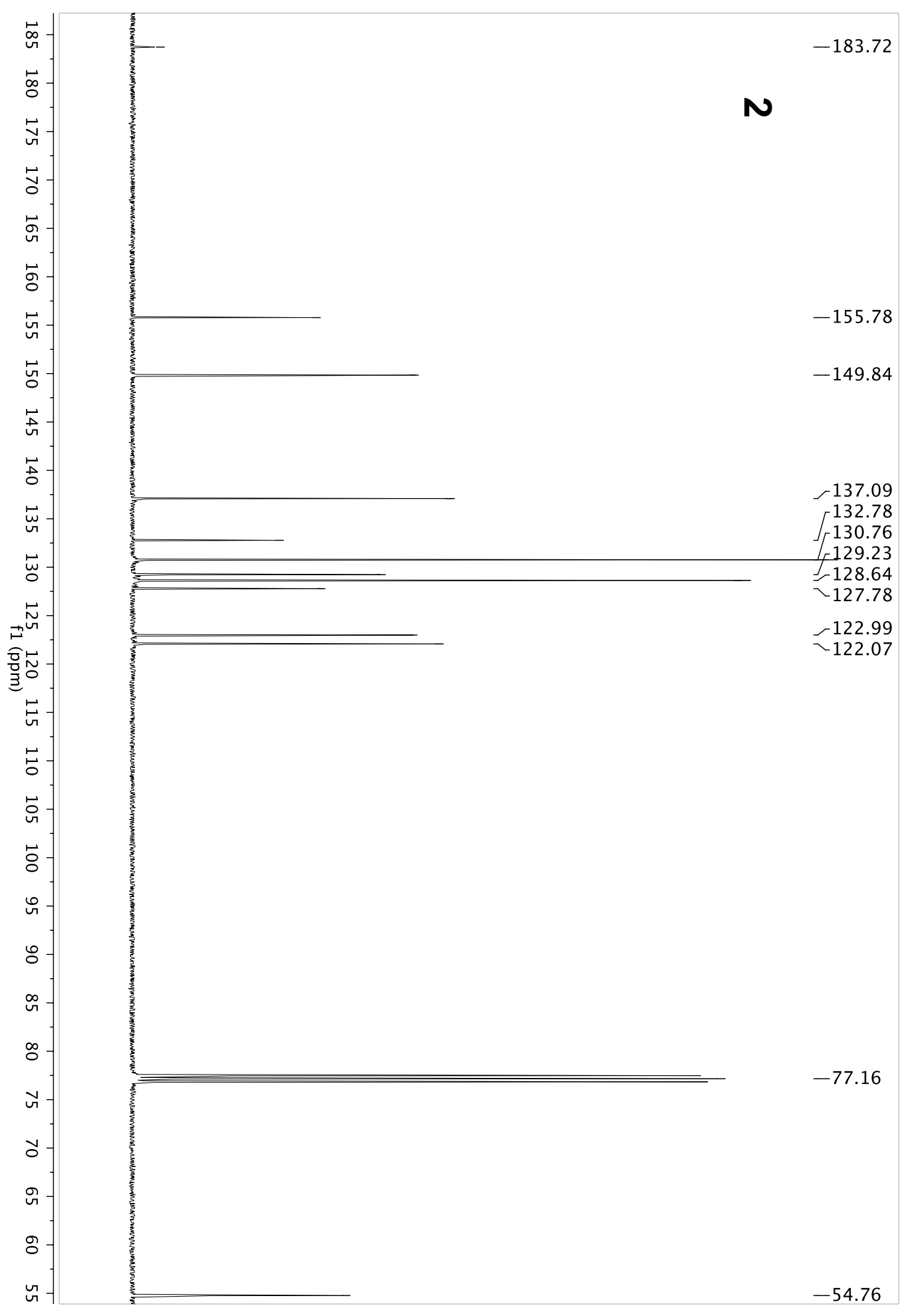

Figure $4:{ }^{13} \mathrm{C}$ NMR spectrum of 2 . 


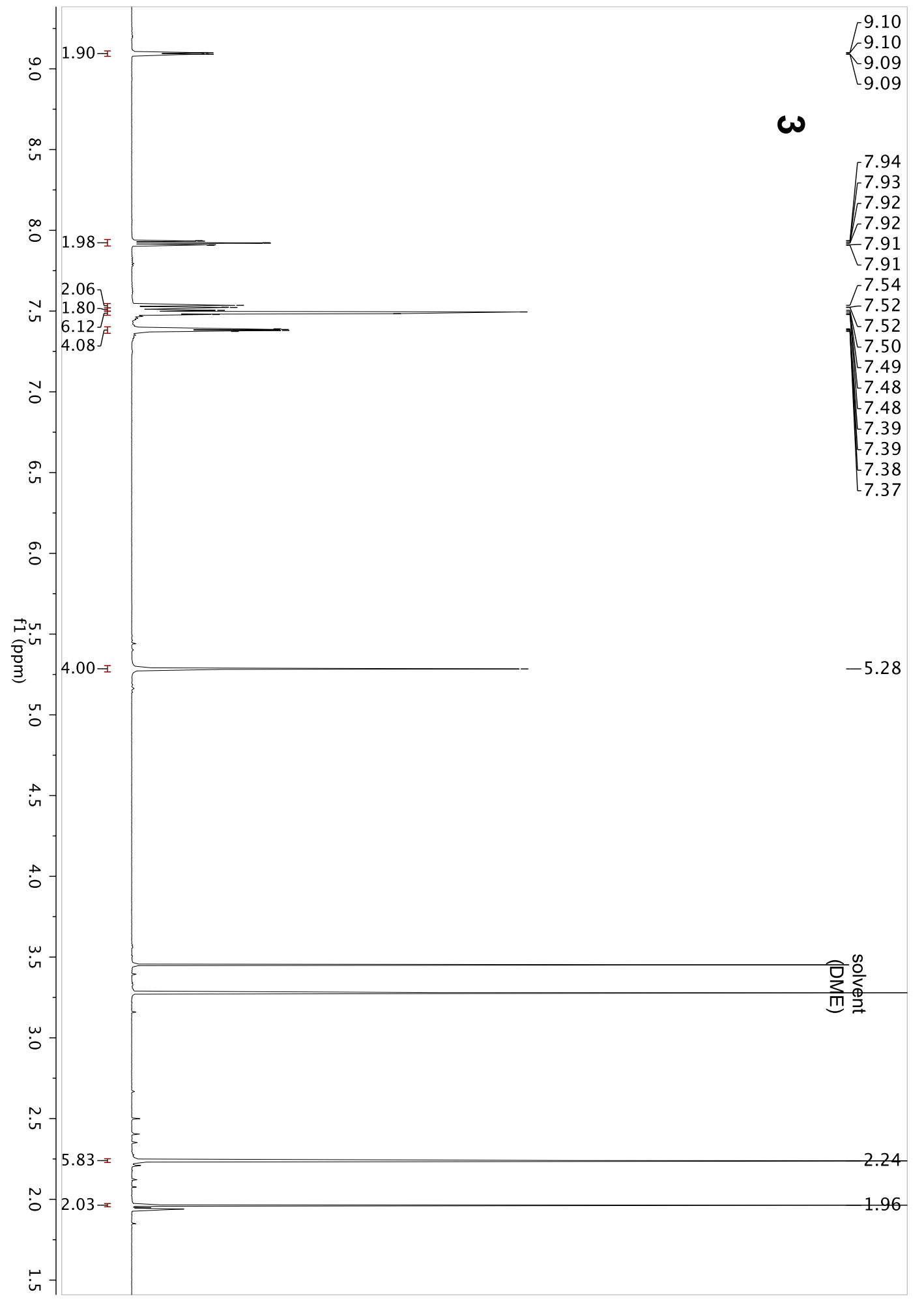

Figure 5: ${ }^{1} \mathrm{H}$ NMR spectrum of 3 . 


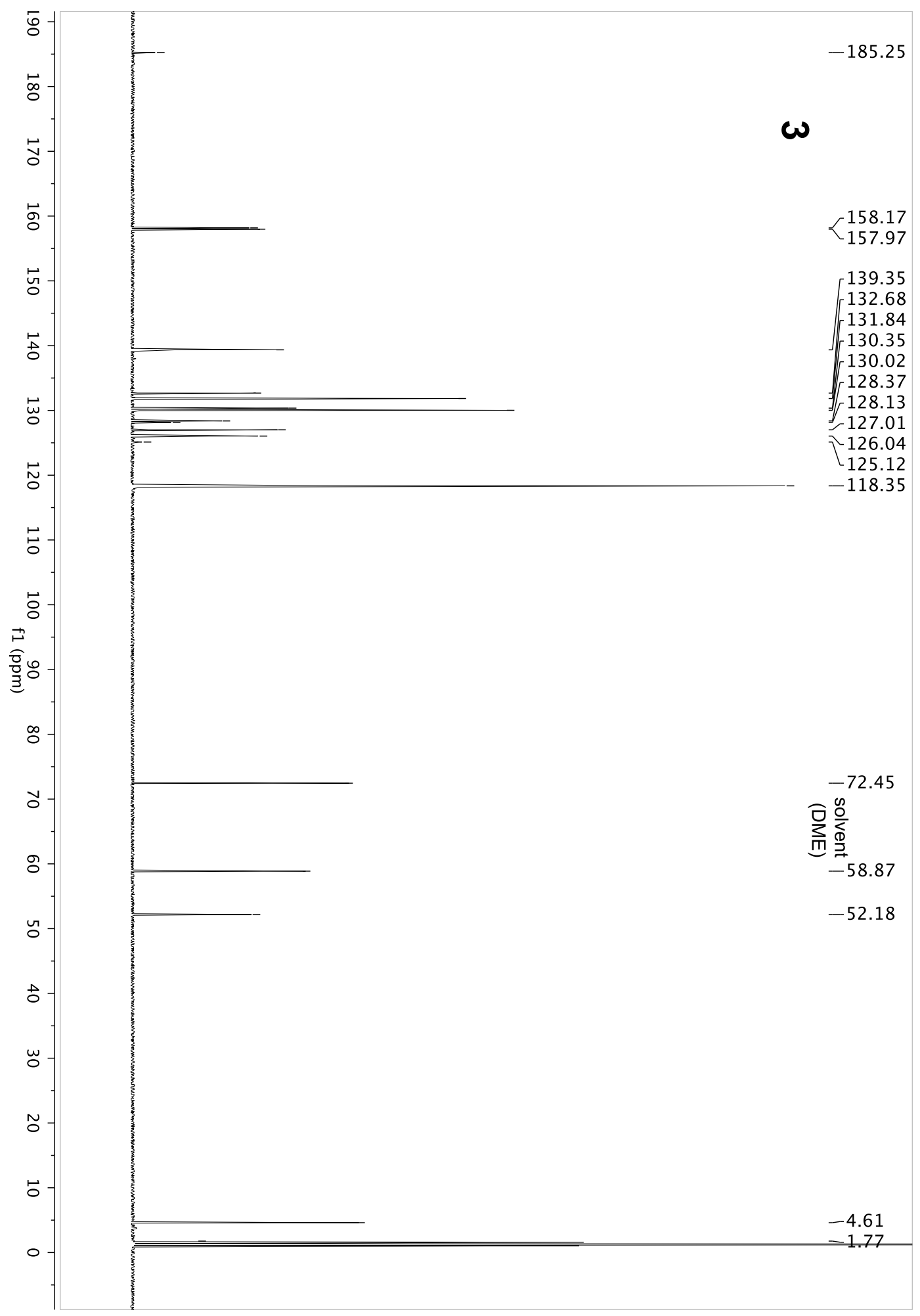

Figure 6: ${ }^{13} \mathrm{C}$ NMR spectrum of $\mathbf{3}$. 


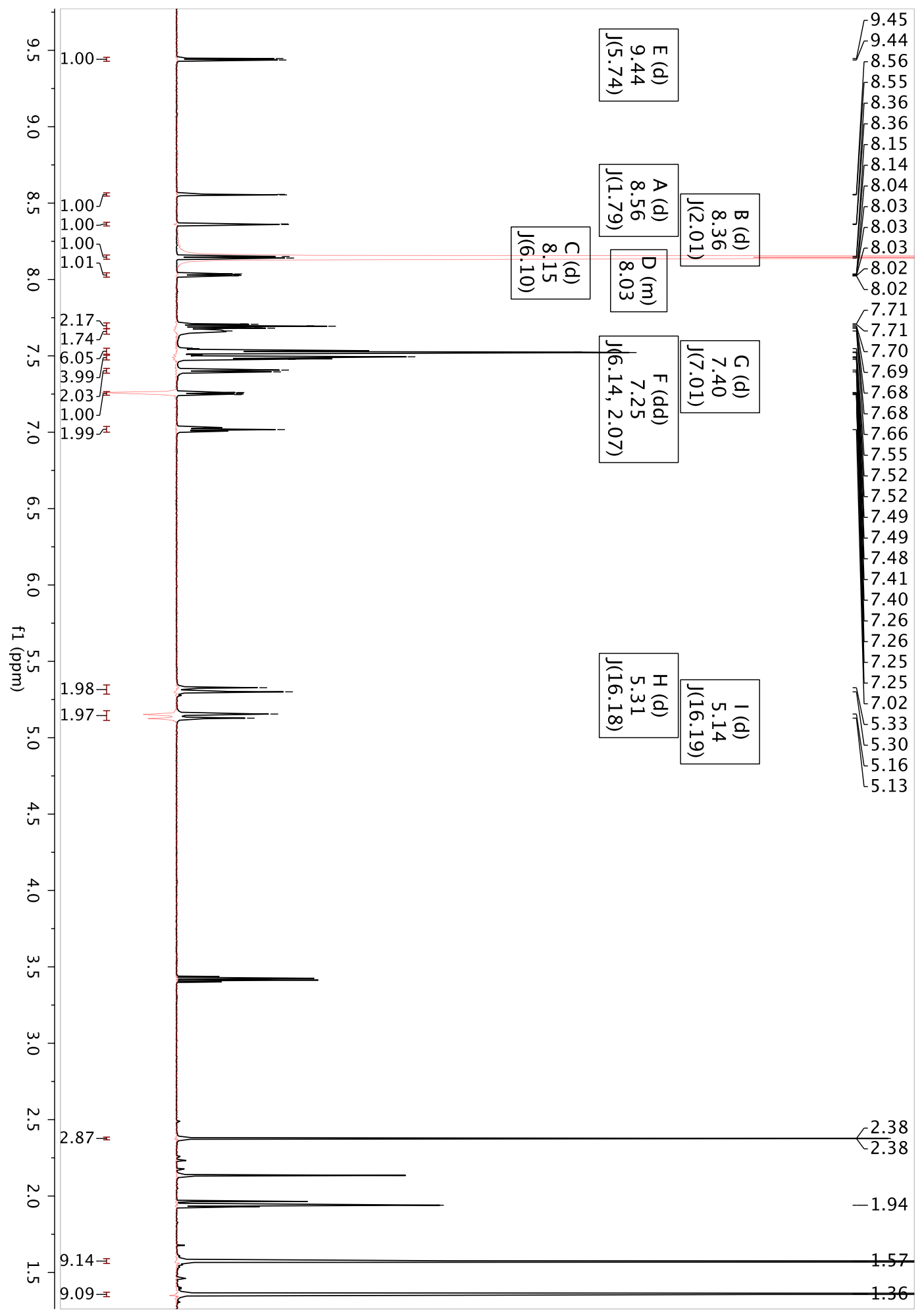

Figure 7: ${ }^{1} \mathrm{H}$ NMR and 1D NOESY spectrum (red line, $600 \mathrm{~ms}$ mixing time, $4 \mathrm{~s}$ relaxation delay, irradiation at $\delta=8.15$ ) of 4 . 


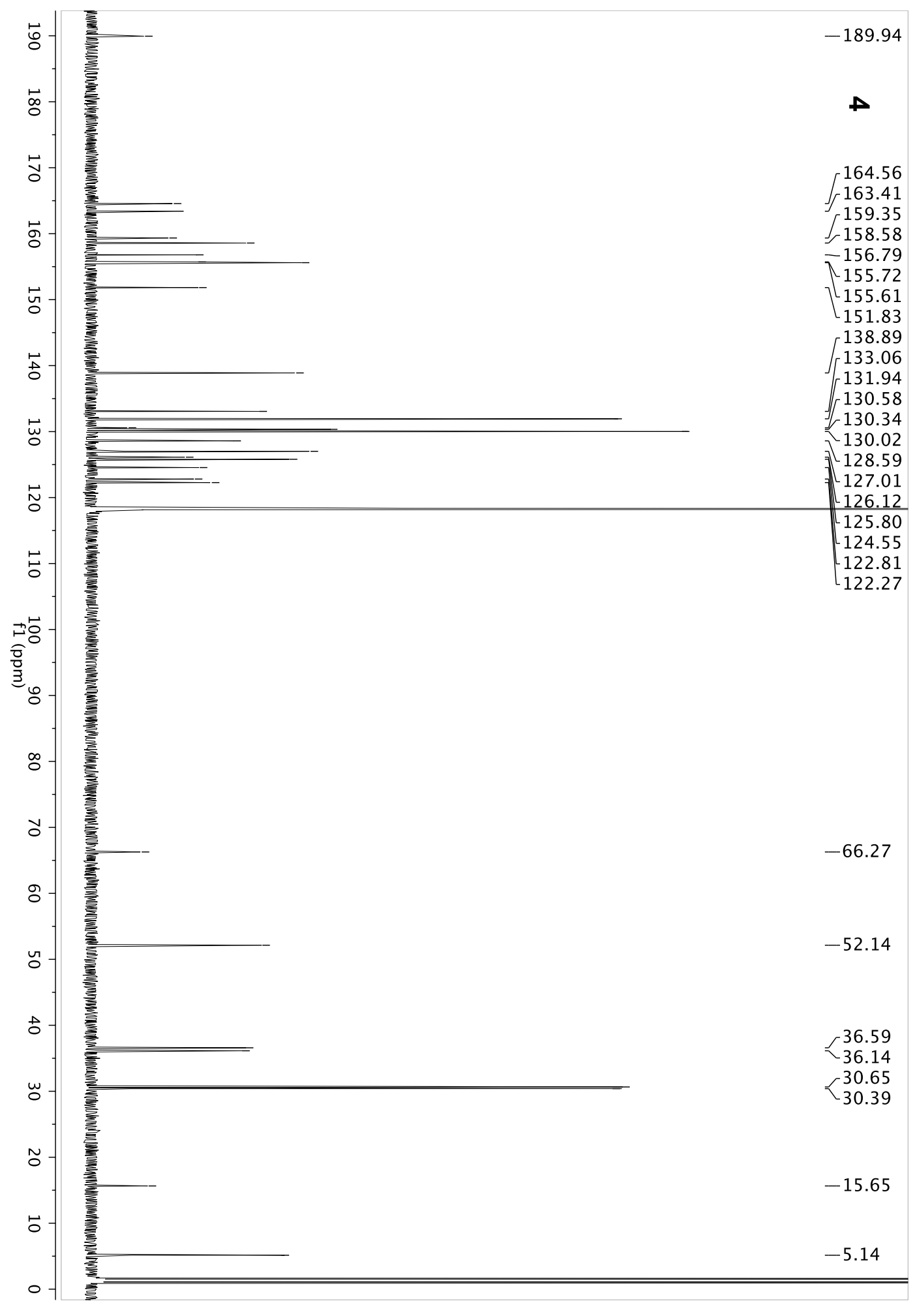

Figure $8:{ }^{13} \mathrm{C}$ NMR spectrum of 4 . 


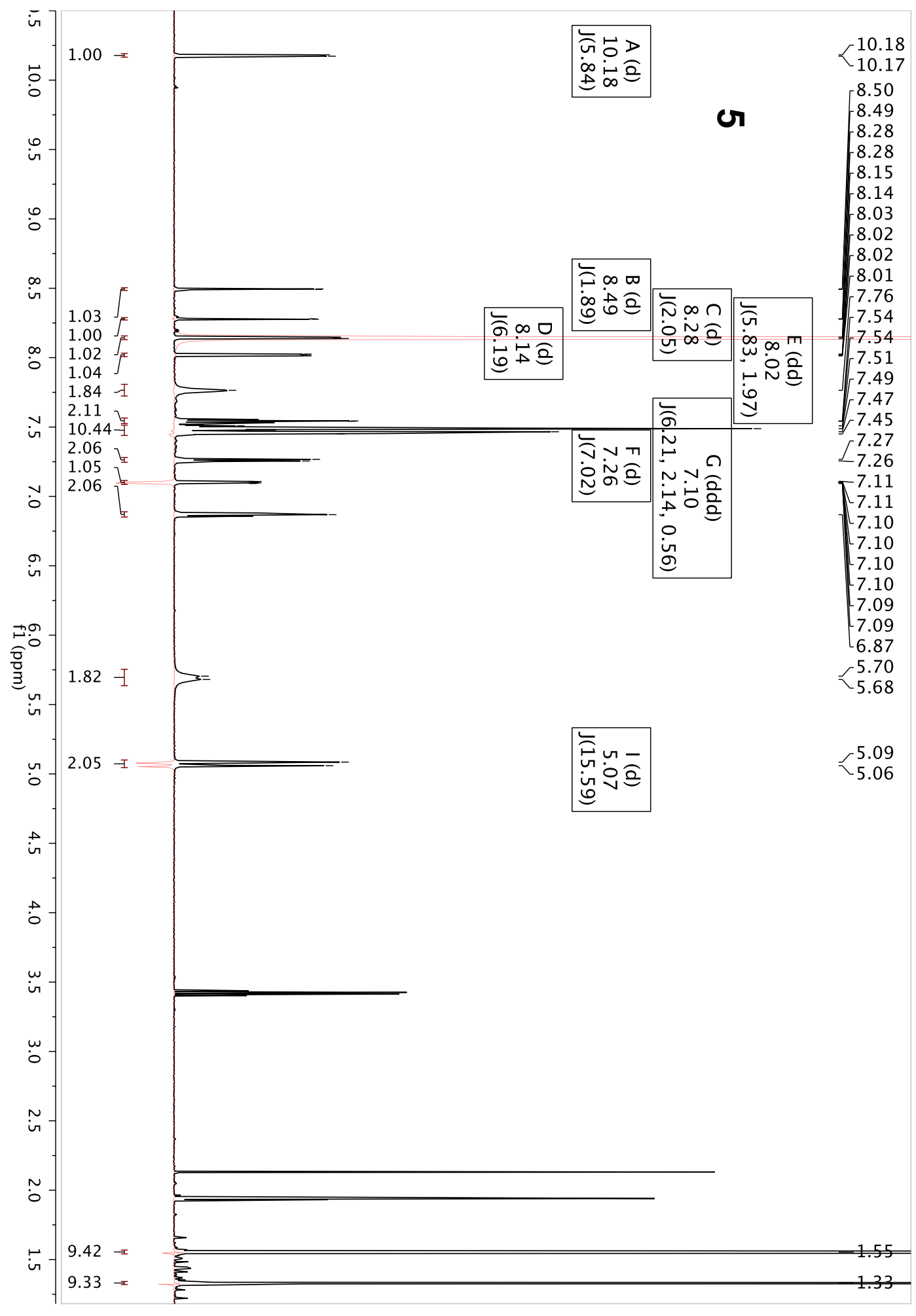

Figure 9: ${ }^{1} \mathrm{H}$ NMR and 1D NOESY spectrum (red line, $600 \mathrm{~ms}$ mixing time, $4 \mathrm{~s}$ relaxation delay, irradiation at $\delta=8.14$ ) of 5 . 


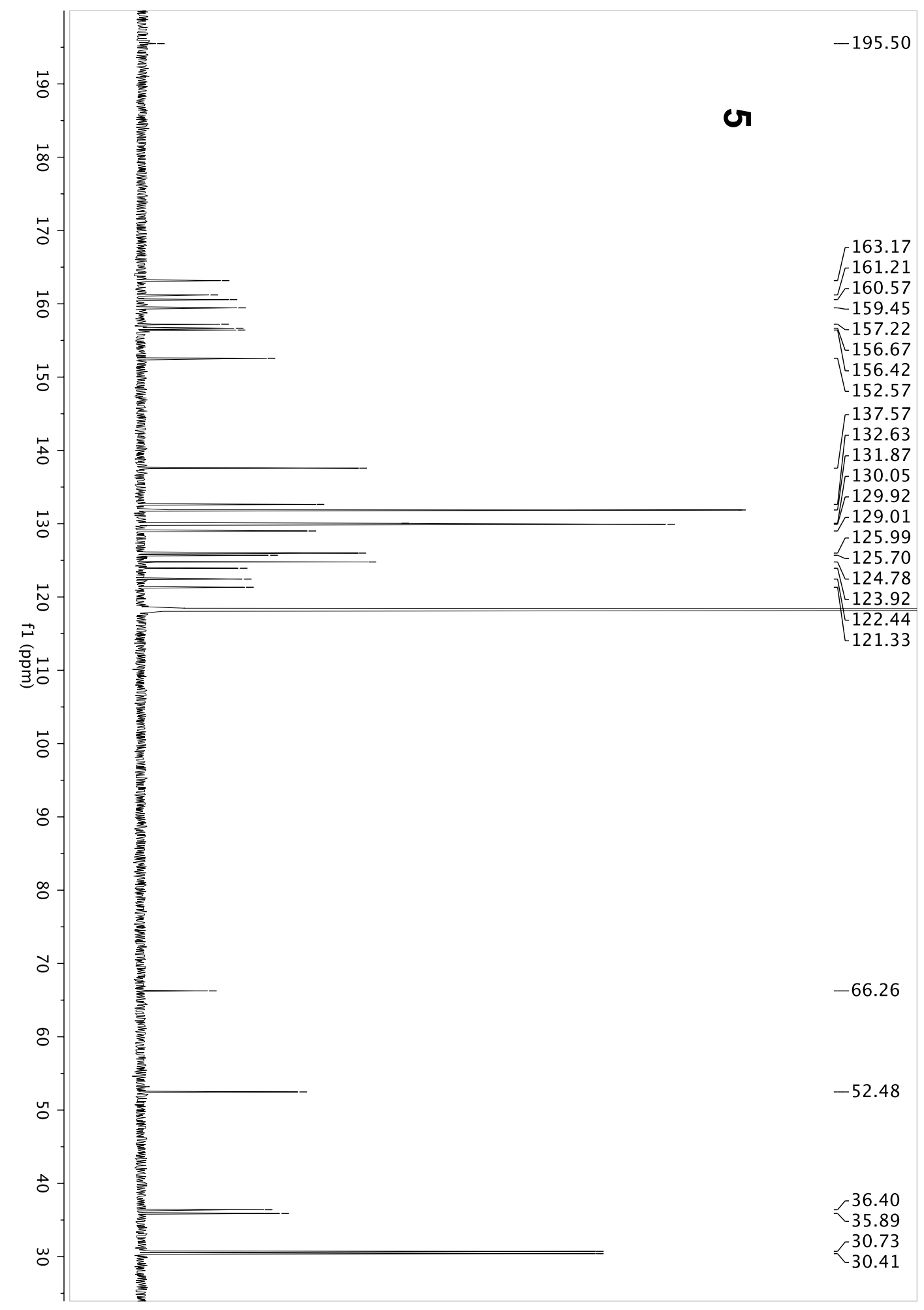

Figure 10: ${ }^{13} \mathrm{C}$ NMR spectrum of 5 . 


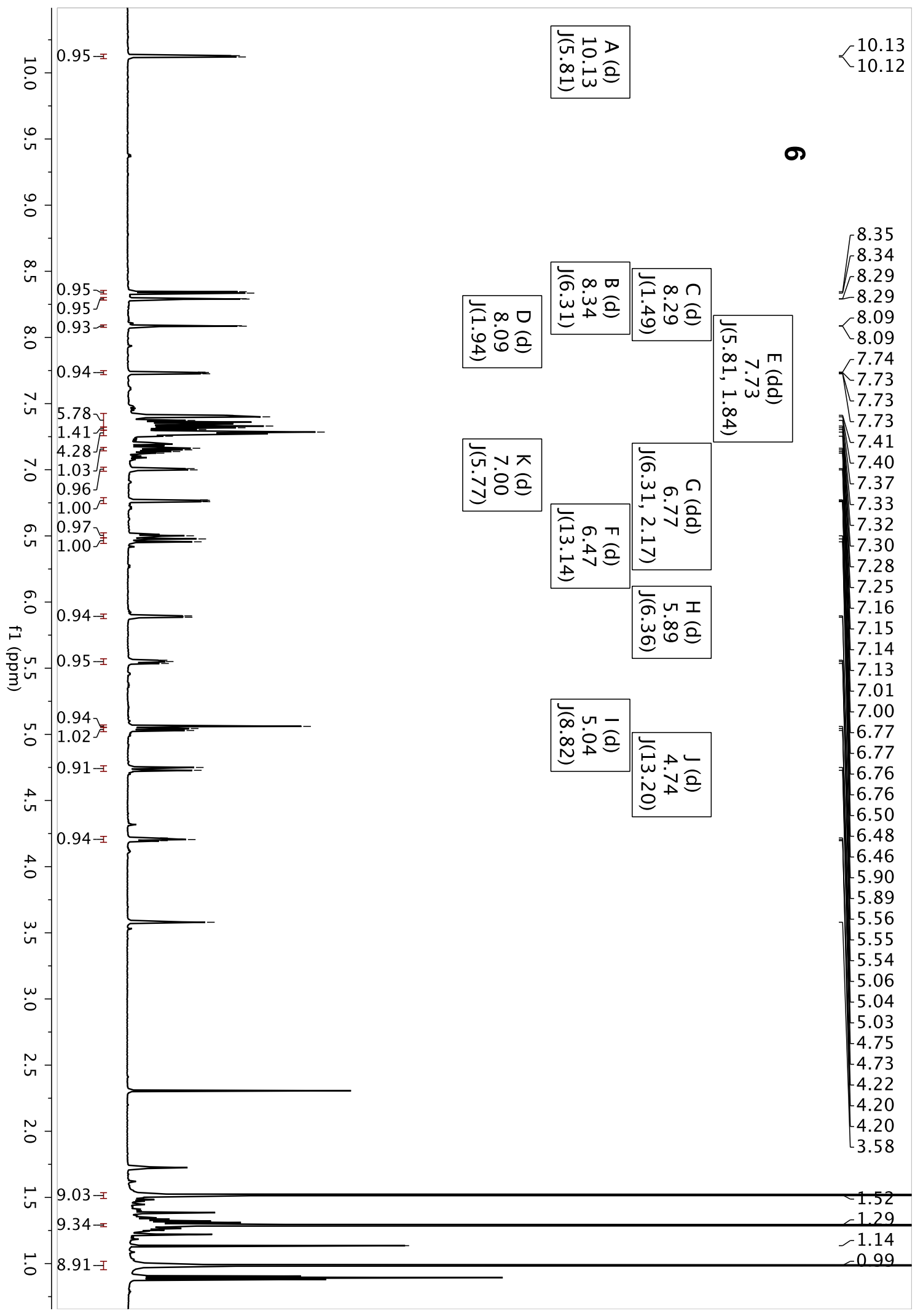

Figure 11: ${ }^{1} \mathrm{H}$ NMR spectrum of 6. 


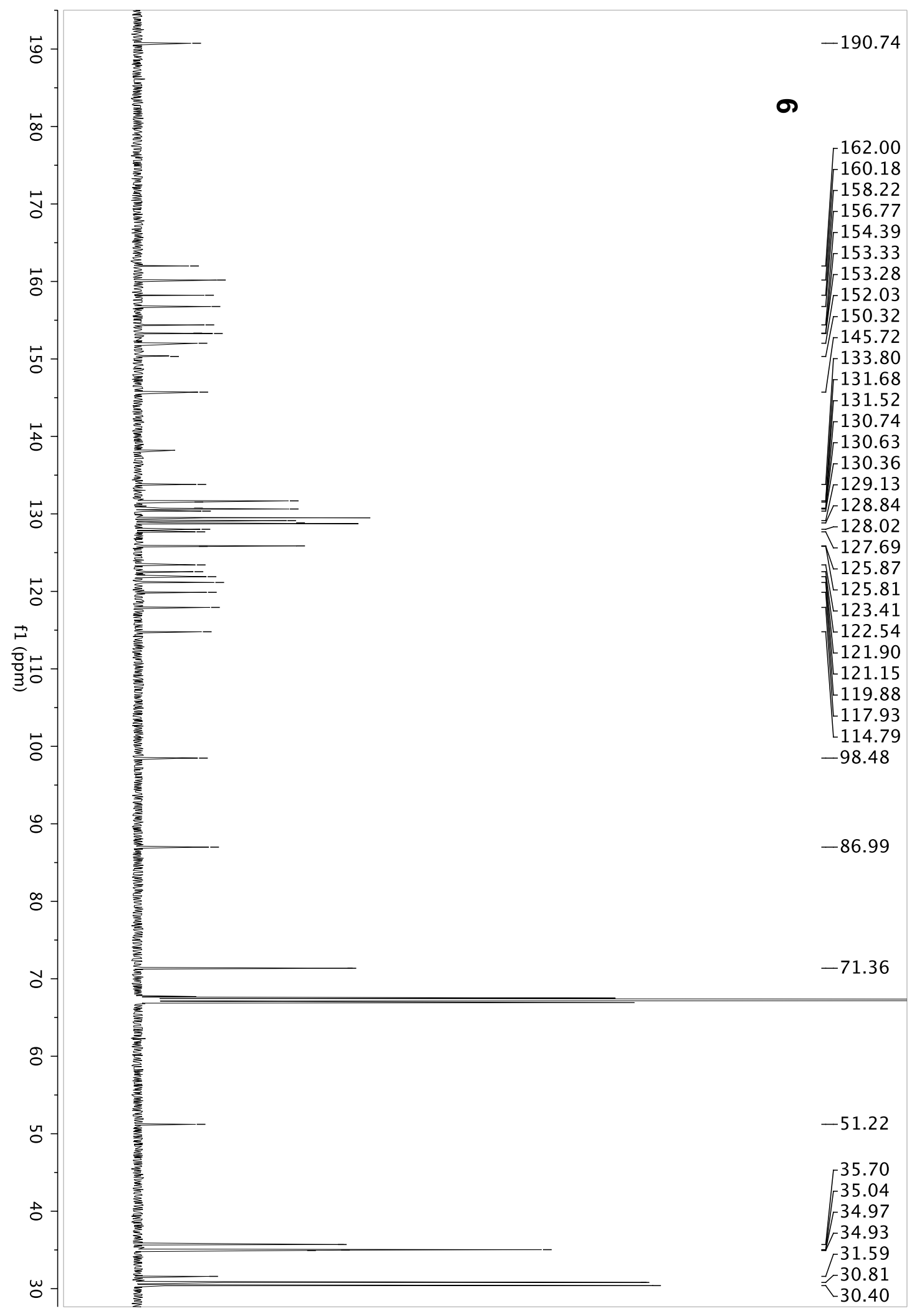

Figure 12: ${ }^{13} \mathrm{C}$ NMR spectrum of 6 . 


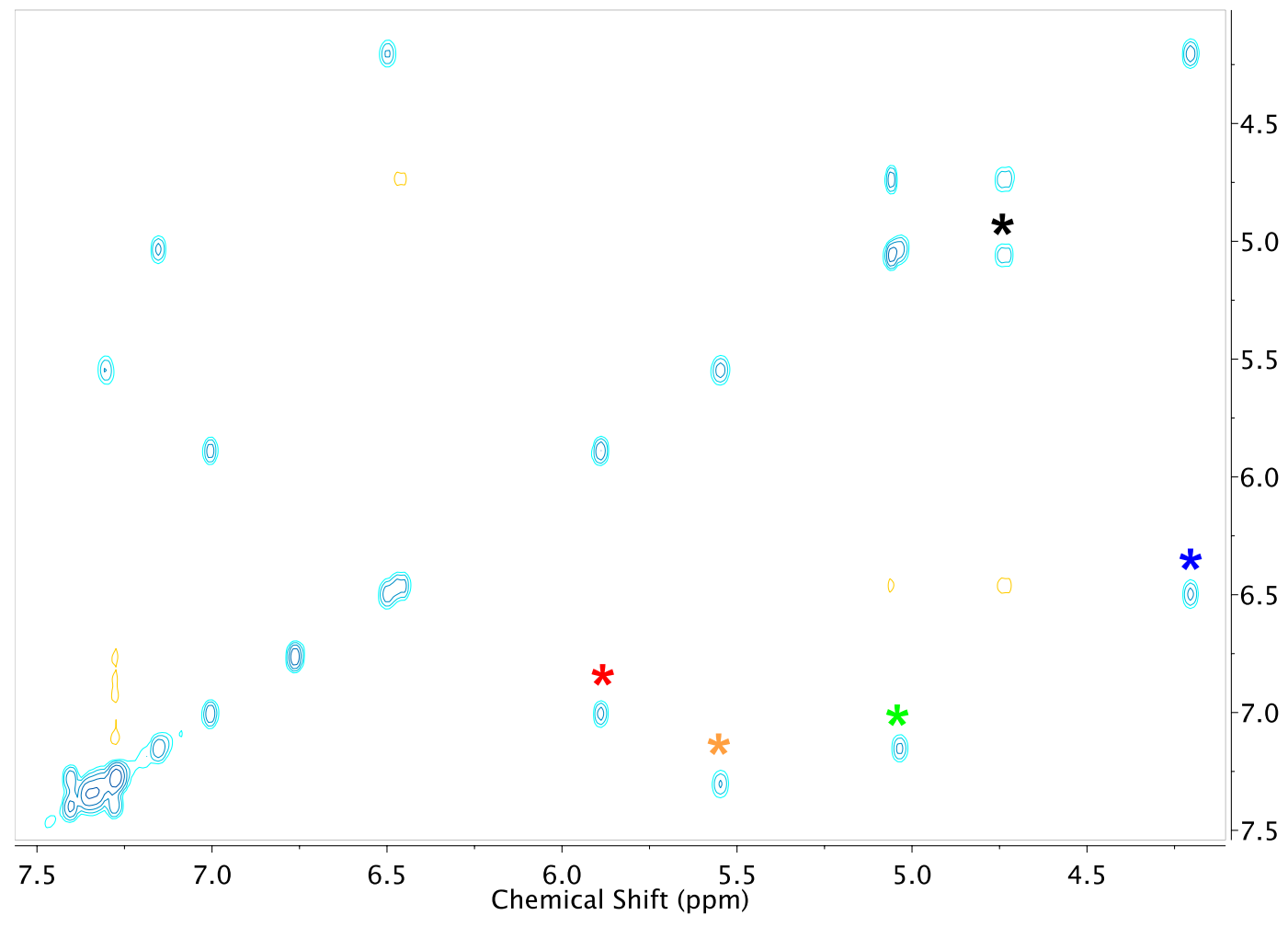

Figure 13: ${ }^{1} \mathrm{H}-{ }^{1} \mathrm{H}$ ROESY spectrum $\left(\mathrm{THF}-\mathrm{d}_{8}, 0{ }^{\circ} \mathrm{C}, 600 \mathrm{~ms}\right.$ mixing time, $1 \mathrm{~s}$ relaxation delay) of 6. The colored asterisks (matched with Scheme 4 in the main text) indicate the protons on the pincer framework undergoing two-site chemical exchange. The exchange cross peak at $\delta=(7.3$, 7.4) belongs to the phenyl rings attached to the N-heterocyclic carbene. 


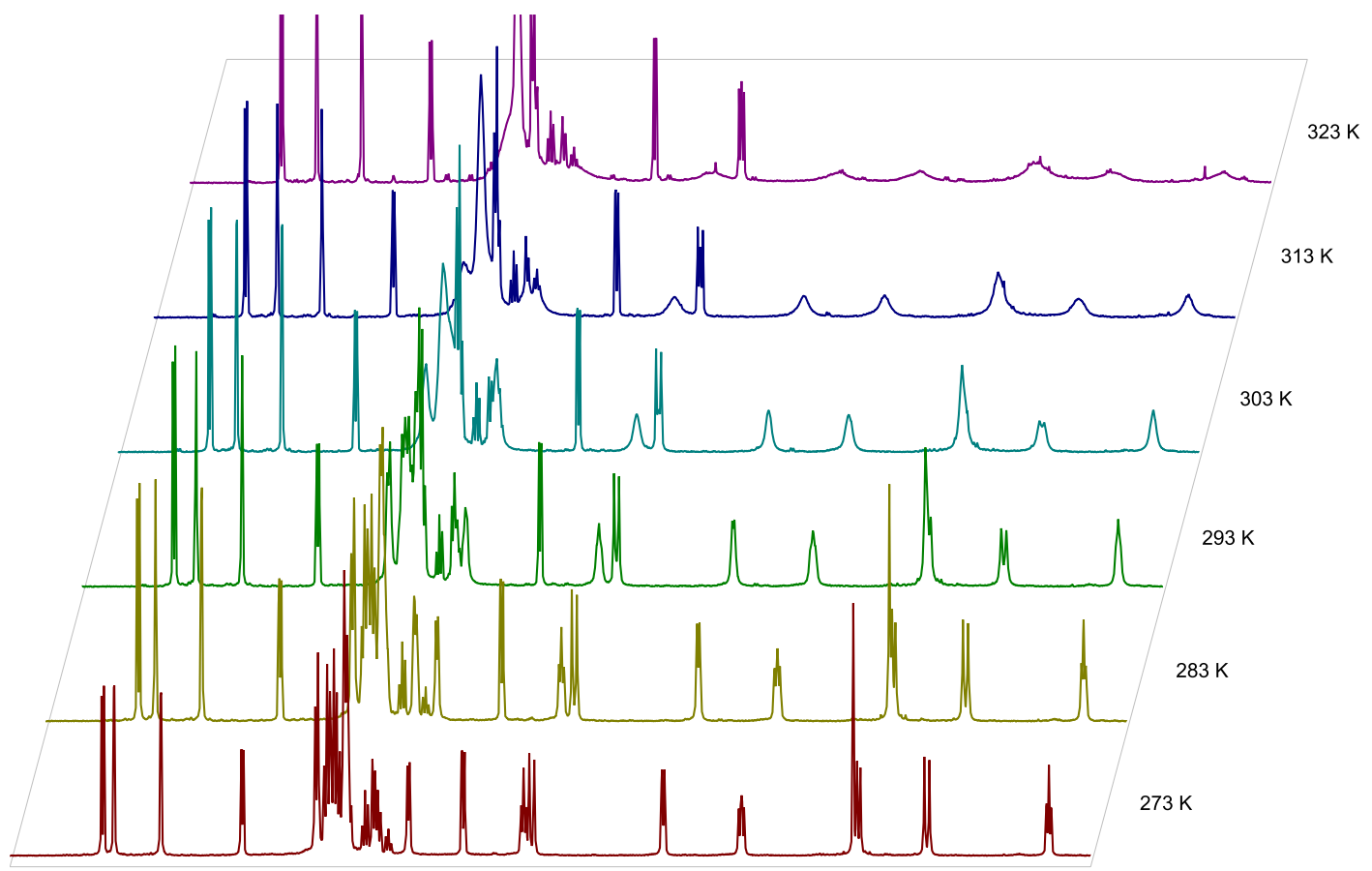

$\begin{array}{lllllllllllllllllllllllll}8.6 & 8.4 & 8.2 & 8.0 & 7.8 & 7.6 & 7.4 & 7.2 & 7.0 & 6.8 & 6.6 & 6.4 & 6.2 & 6.0 & 5.8 & 5.6 & 5.4 & 5.2 & 5.0 & 4.8 & 4.6 & 4.4 & 4.2\end{array}$

Figure 14: Stacked ${ }^{1}$ H VT-NMR spectrum of 6.

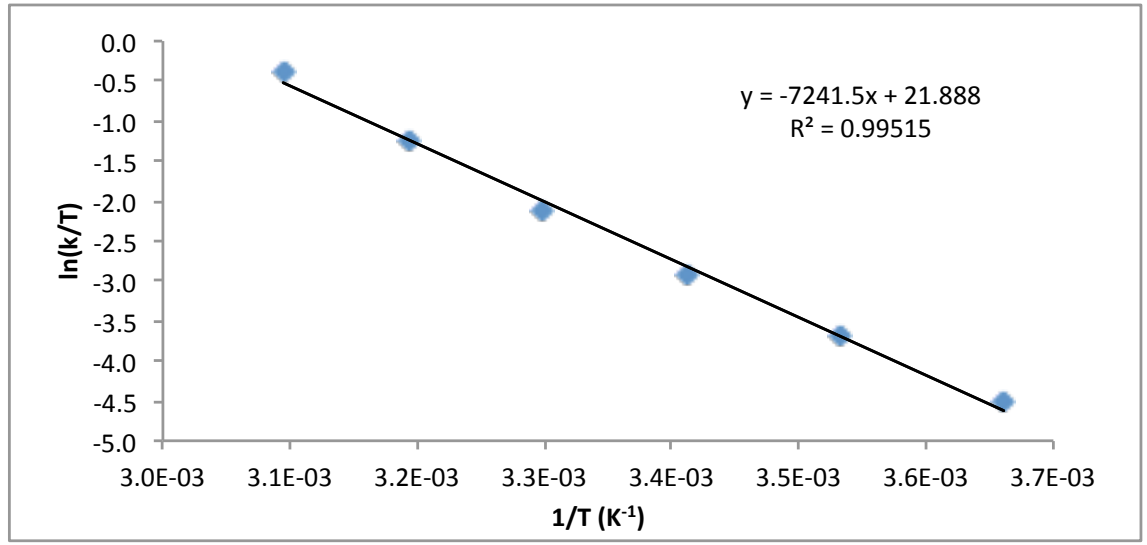

Figure 15: Eyring plot of 6. 


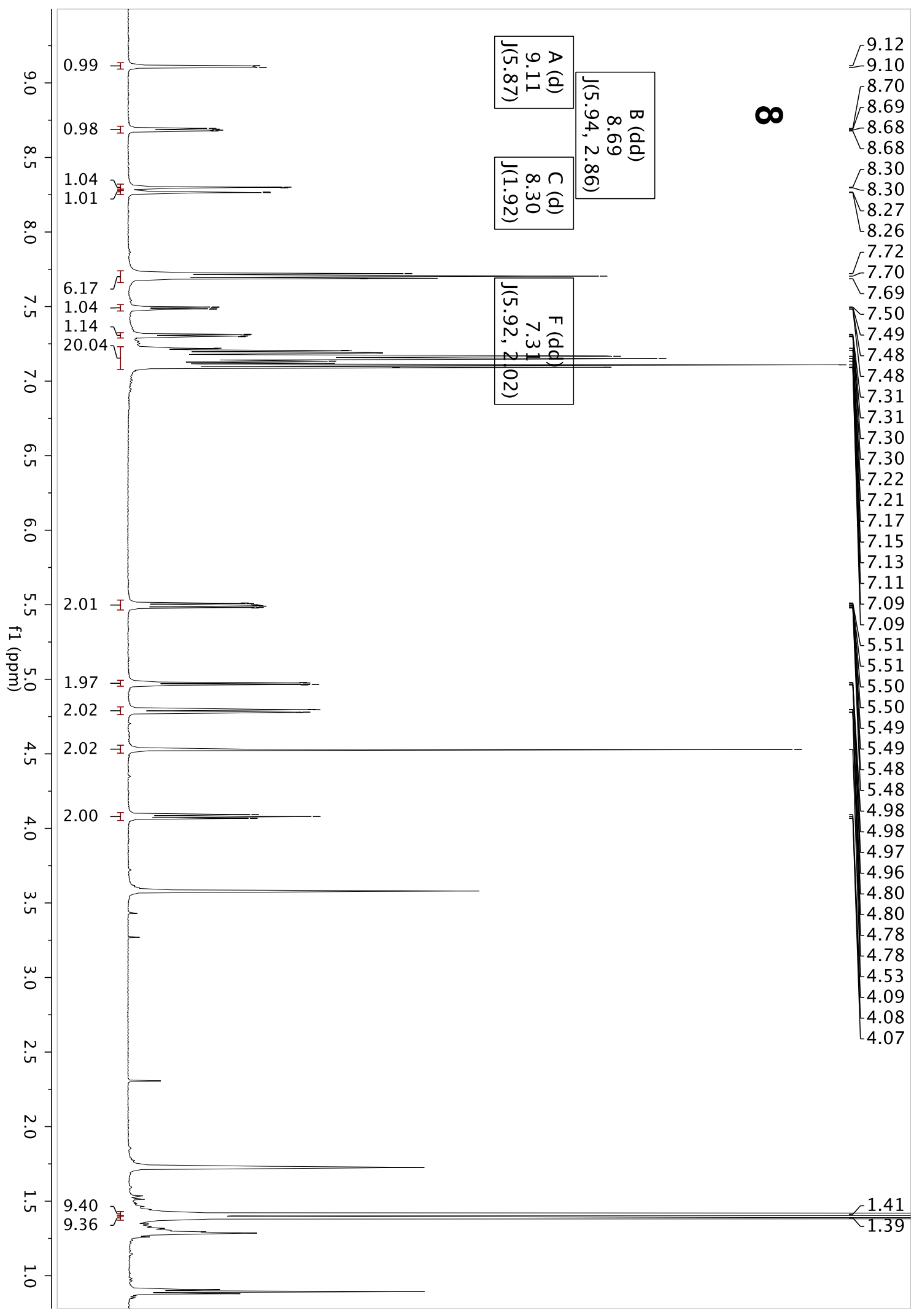

Figure 16: ${ }^{1} \mathrm{H}$ NMR spectrum of 8 . 


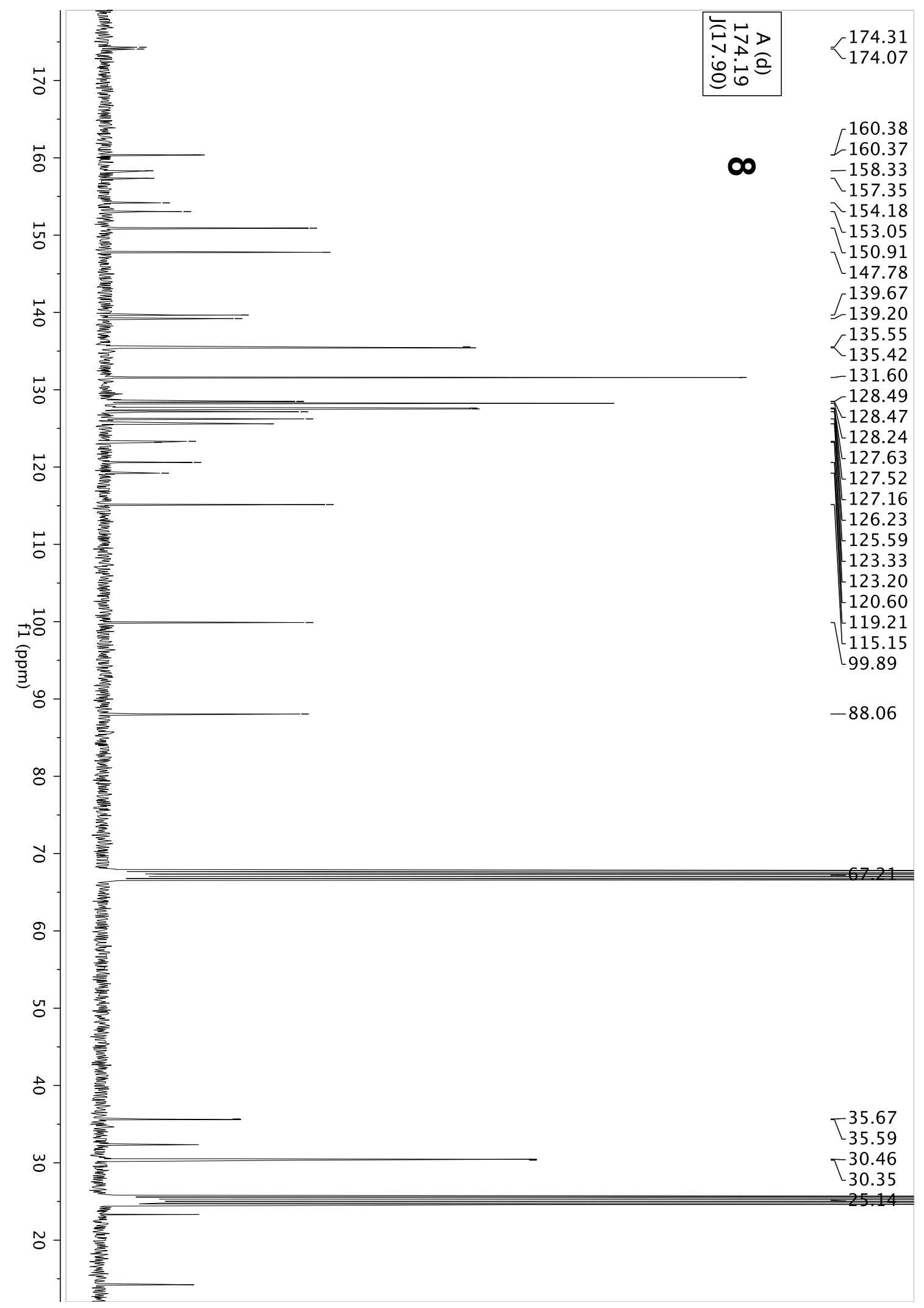

Figure 17: ${ }^{13} \mathrm{C}$ NMR spectrum of 8 . 


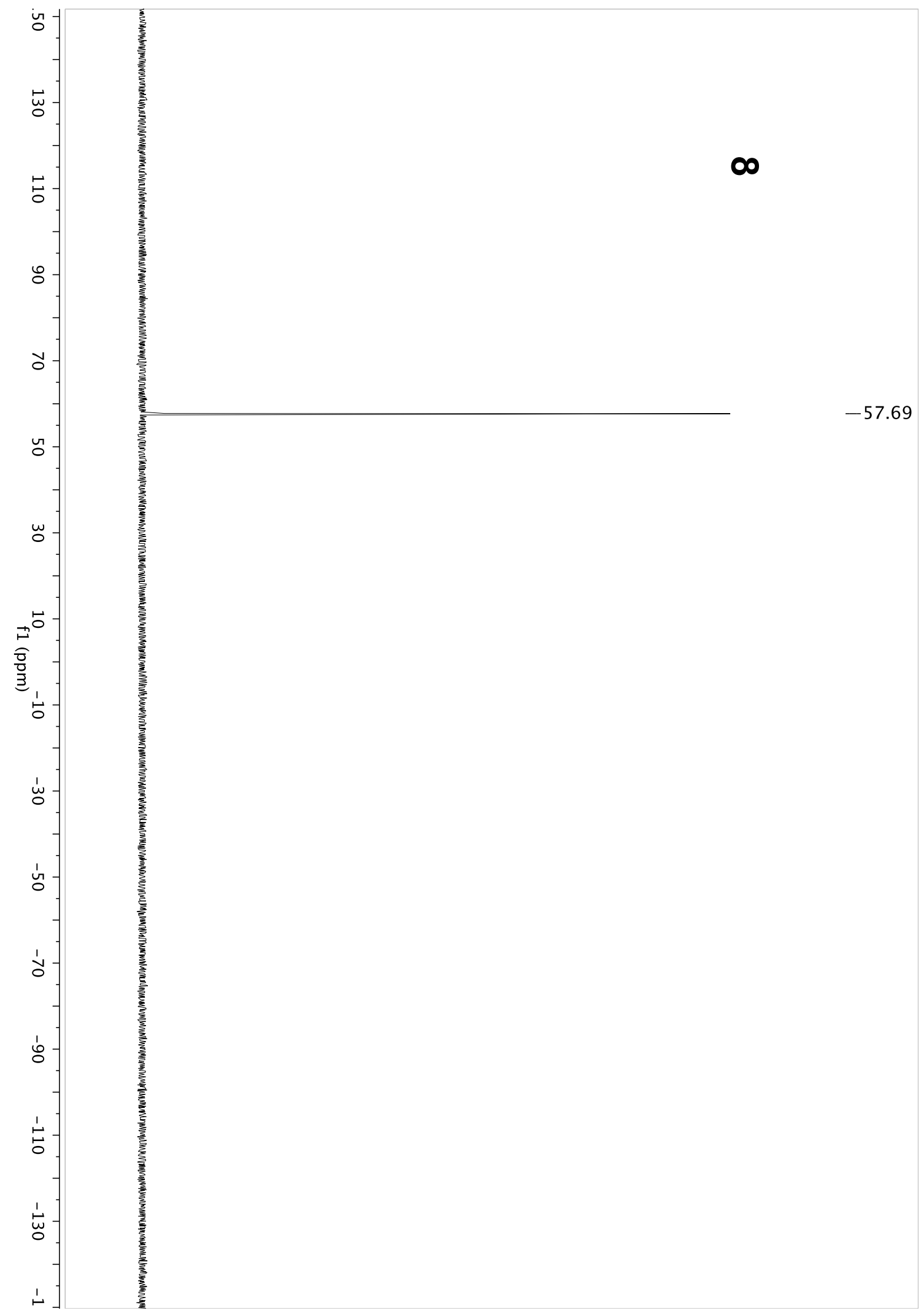

Figure 18: ${ }^{31} \mathrm{P}$ NMR spectrum of 8 . 


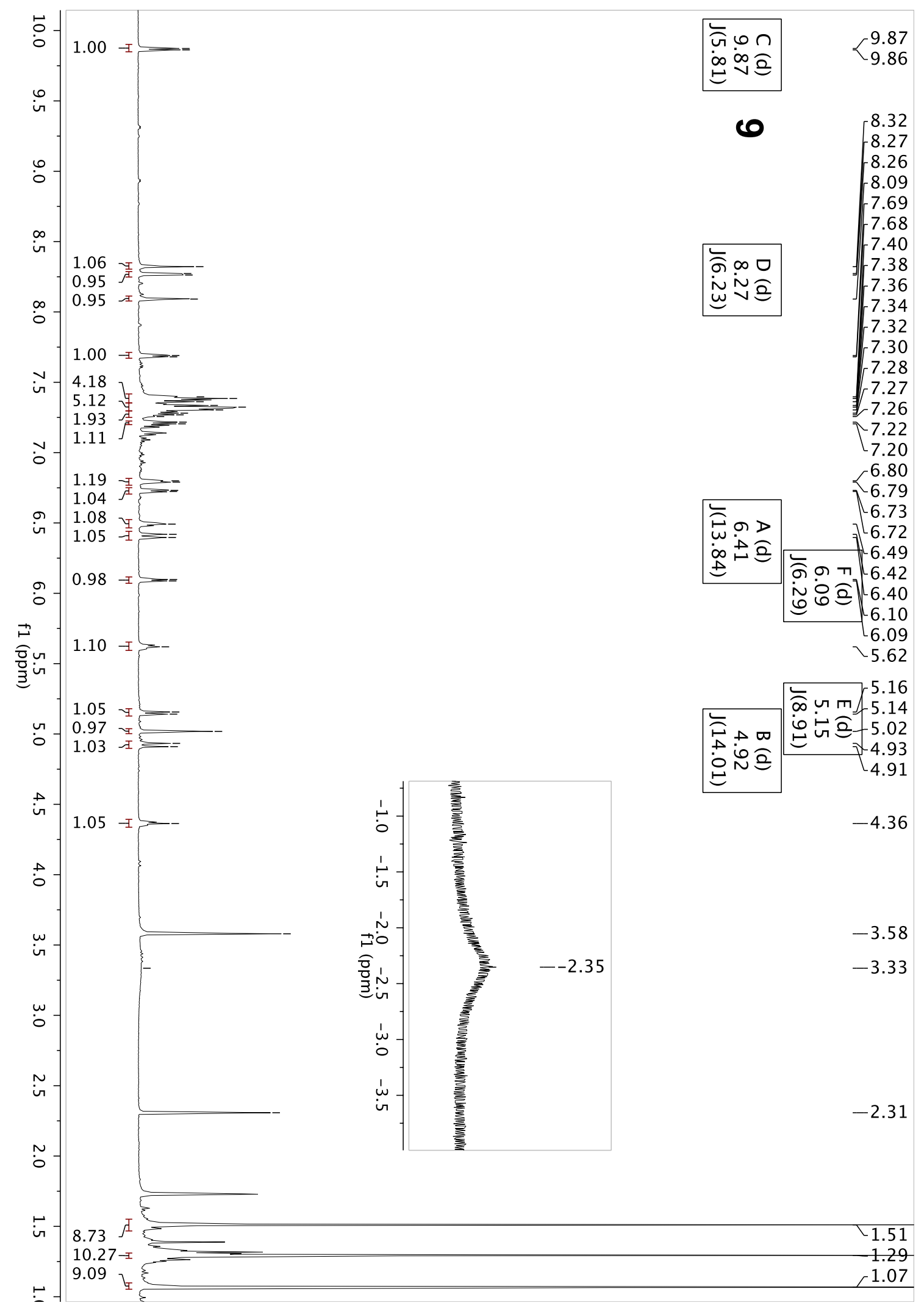

Figure 19: ${ }^{1} \mathrm{H}$ NMR spectrum of 9 . 


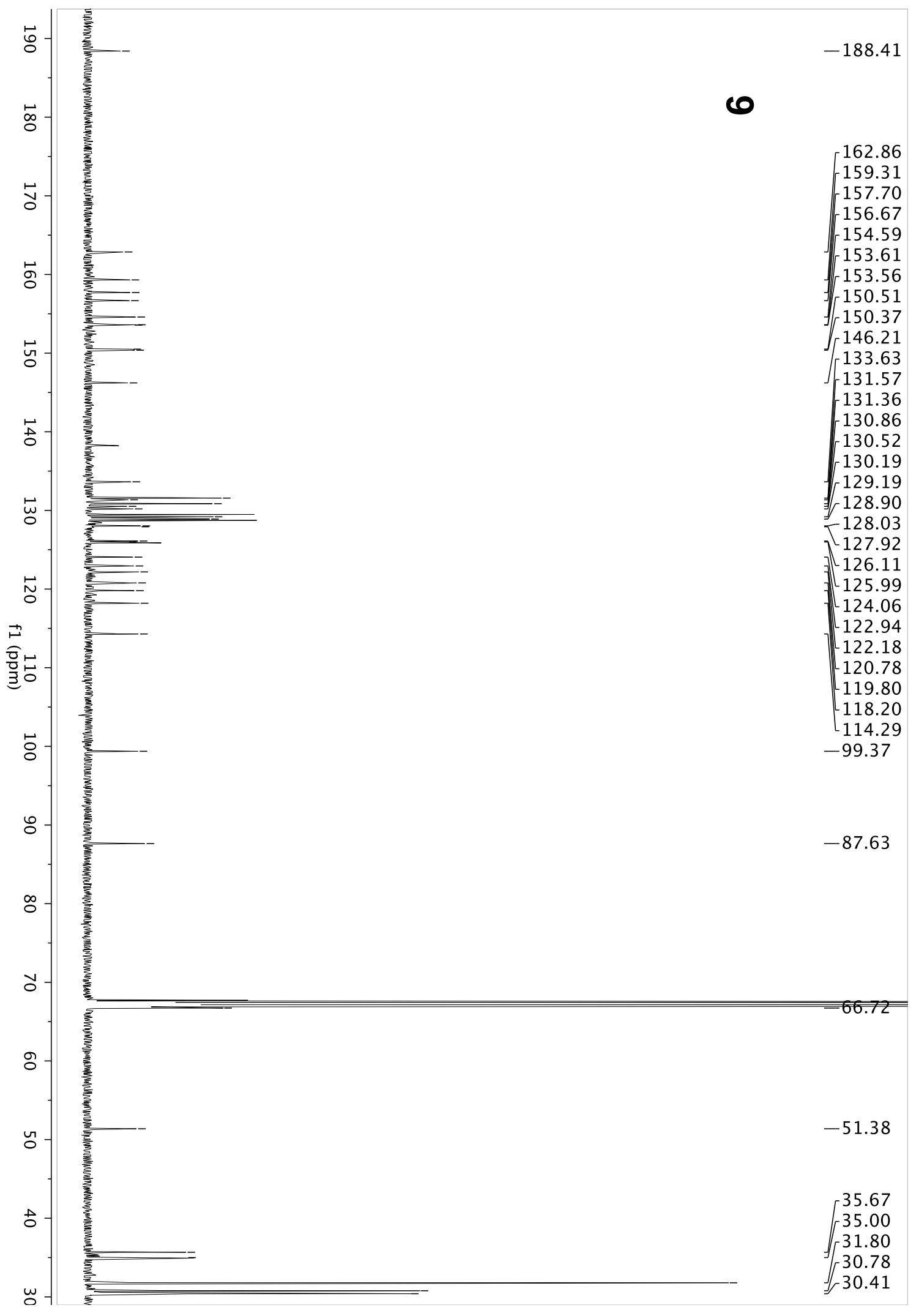

Figure 20: ${ }^{13} \mathrm{C}$ NMR spectrum of 9 . 


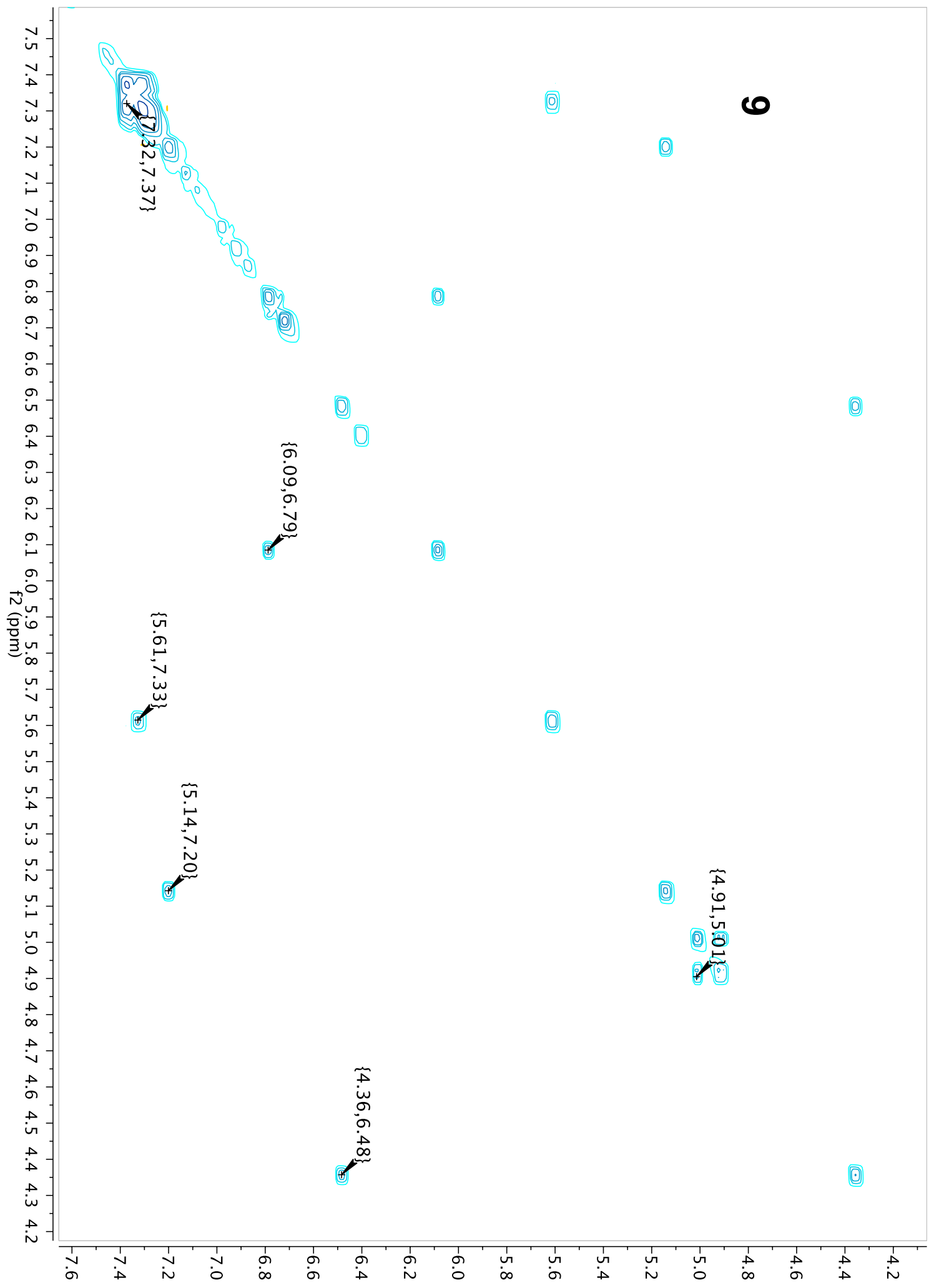

Figure 21: ${ }^{1} \mathrm{H}-{ }^{1} \mathrm{H}$ ROESY spectrum $\left(\mathrm{THF}-\mathrm{d}_{8}, 0{ }^{\circ} \mathrm{C}, 600 \mathrm{~ms}\right.$ mixing time, $1 \mathrm{~s}$ relaxation delay) of 8. 


\section{X-Ray crystal structure and refinement data.}

Table 1: Selected X-Ray crystal structure and refinement data for complexes $\mathbf{1}, \mathbf{3}, \mathbf{6}$, and $\mathbf{8}$.

\begin{tabular}{|c|c|c|c|}
\hline Compound & 1. $\left(\mathrm{H}_{2} \mathrm{O}\right)_{2}$ & 3. $\mathrm{CH}_{2} \mathrm{Cl}_{2}$ & 6. $\mathrm{C}_{5} \mathrm{H}_{12}$ \\
\hline empirical formula & $\mathrm{C}_{27} \mathrm{H}_{27} \mathrm{BrN}_{4} \mathrm{O}_{2}$ & $\mathrm{C}_{34} \mathrm{H}_{33} \mathrm{Cl}_{2} \mathrm{~F}_{12} \mathrm{~N}_{7} \mathrm{P}_{2} \mathrm{Ru}$ & $\mathrm{C}_{54} \mathrm{H}_{66} \mathrm{~N}_{6} \mathrm{ORu}$ \\
\hline formula mass & 519.43 & 1001.58 & 916.19 \\
\hline temp. $(\mathrm{K})$ & \multicolumn{3}{|c|}{$147(2)$} \\
\hline crystal system & Triclinic & Triclinic & Monoclinic \\
\hline space group & $P \overline{1}$ & $P \overline{1}$ & $P 2_{1} / n$ \\
\hline $\mathrm{a}(\AA)$ & $10.0240(19)$ & $11.4038(9)$ & $21.480(3)$ \\
\hline $\mathrm{b}(\AA)$ & $10.447(2)$ & $13.1369(10)$ & $10.0850(12)$ \\
\hline c $(\AA)$ & $12.072(2)$ & $14.5455(11)$ & $22.272(3)$ \\
\hline$\alpha\left(^{\circ}\right)$ & $78.011(5)$ & $75.854(2)$ & 90 \\
\hline$\beta\left({ }^{\circ}\right)$ & $88.339(4)$ & $72.083(2)$ & $90.234(3)$ \\
\hline$\gamma\left({ }^{\circ}\right)$ & $78.932(4)$ & $85.274(2)$ & 90 \\
\hline volume $\left(\AA^{3}\right)$ & $1213.5(4)$ & $2010.5(3)$ & $4824.6(10)$ \\
\hline $\mathrm{Z}$ & 2 & 2 & 4 \\
\hline calc. density $\left(\mathrm{g} / \mathrm{cm}^{3}\right)$ & 1.422 & 1.655 & 1.261 \\
\hline $\begin{array}{l}\text { absorption coeff. } \\
\left(\mathrm{mm}^{-1}\right)\end{array}$ & 1.726 & 0.695 & 0.369 \\
\hline $\mathrm{F}(000)$ & 536 & 1004 & 1936 \\
\hline crystal size $\left(\mathrm{mm}^{3}\right)$ & $0.280 \times 0.200 \times 0.100$ & $0.400 \times 0.260 \times 0.130$ & $0.290 \times 0.120 \times 0.030$ \\
\hline$\theta$ range collected $\left(^{\circ}\right)$ & $1.725-27.530$ & $1.512-27.538$ & $1.314-27.531$ \\
\hline $\begin{array}{l}\text { reflections } \\
\text { collected/unique }\end{array}$ & $35658 / 5546$ & $33752 / 9128$ & $60817 / 11081$ \\
\hline $\begin{array}{l}\text { completeness to } \\
\theta=27.52^{\circ}(\%)\end{array}$ & 99.8 & 99.2 & 99.9 \\
\hline absorption correction & \multicolumn{3}{|c|}{ Semi-empirical from equivalents } \\
\hline $\begin{array}{l}\max . \text { and min. } \\
\text { transmission }\end{array}$ & $0.7456,0.6286$ & $0.7455,0.6656$ & $0.7456,0.6796$ \\
\hline $\begin{array}{l}\text { data / restraints / } \\
\text { parameters }\end{array}$ & $5546 / 0 / 323$ & $9128 / 91 / 548$ & $11081 / 0 / 570$ \\
\hline goodness-of-fit on $\mathrm{F}^{2}$ & 1.054 & 1.032 & 1.036 \\
\hline$R_{1}(I>2 \sigma(I))^{\mathrm{a}}$ & 0.0228 & 0.0433 & 0.0423 \\
\hline$w R_{2}$ (all data) $^{\mathrm{b}}$ & 0.0623 & 0.1176 & 0.1014 \\
\hline
\end{tabular}

${ }^{\mathrm{a}} R_{1}=\Sigma\left(F_{o}-F_{c}\right) / \Sigma\left(F_{o}\right)$

${ }^{\mathrm{b}} w R_{2}=\sqrt{\Sigma\left[w\left(F_{o}^{2}-F_{c}^{2}\right)^{2}\right] / \Sigma\left[w\left(F_{o}^{2}\right)^{2}\right]}$ 


\begin{tabular}{|c|c|}
\hline Compound & $\mathbf{8} \cdot\left(\mathrm{C}_{7} \mathrm{H}_{8}\right)_{0.75} \cdot\left(\mathrm{C}_{5} \mathrm{H}_{12}\right)_{0.25}$ \\
\hline empirical formula & $\mathrm{C}_{69.5} \mathrm{H}_{68} \mathrm{~N}_{6} \mathrm{PRu}$ \\
\hline formula mass & 1119.33 \\
\hline temp. $(\mathrm{K})$ & $147(2)$ \\
\hline crystal system & Triclinic \\
\hline space group & $P \overline{1}$ \\
\hline $\mathrm{a}(\AA)$ & $18.1397(7)$ \\
\hline $\mathrm{b}(\AA)$ & $18.7592(9)$ \\
\hline$c(\AA)$ & $20.7229(9)$ \\
\hline$\alpha\left(^{\circ}\right)$ & $89.894(3)$ \\
\hline$\beta\left(^{\circ}\right)$ & $72.527(2)$ \\
\hline$\gamma\left({ }^{\circ}\right)$ & $67.912(3)$ \\
\hline volume $\left(\AA^{3}\right)$ & $6183.3(5)$ \\
\hline $\mathrm{Z}$ & 4 \\
\hline calc. density $\left(\mathrm{g} / \mathrm{cm}^{3}\right)$ & 1.202 \\
\hline $\begin{array}{l}\text { absorption coeff. } \\
\left(\mathrm{mm}^{-1}\right)\end{array}$ & 2.634 \\
\hline $\mathrm{F}(000)$ & 2344 \\
\hline crystal size $\left(\mathrm{mm}^{3}\right)$ & $0.080 \times 0.050 \times 0.050$ \\
\hline$\theta$ range collected $\left(^{\circ}\right)$ & $2.253-68.241$ \\
\hline $\begin{array}{l}\text { reflections } \\
\text { collected/unique }\end{array}$ & $135915 / 21971$ \\
\hline $\begin{array}{l}\text { completeness to } \\
\theta=27.52^{\circ}(\%)\end{array}$ & 98.1 \\
\hline absorption correction & $\begin{array}{l}\text { Semi-empirical from } \\
\text { equivalents }\end{array}$ \\
\hline $\begin{array}{l}\text { max. and min. } \\
\text { transmission }\end{array}$ & $0.8796,0.8170$ \\
\hline $\begin{array}{l}\text { data / restraints / } \\
\text { parameters }\end{array}$ & $21971 / 23 / 1337$ \\
\hline goodness-of-fit on $\mathrm{F}^{2}$ & 0.977 \\
\hline$R_{1}(I>2 \sigma(I))^{\mathrm{a}}$ & 0.0741 \\
\hline$w R_{2}(\text { all data) })^{\mathrm{b}}$ & 0.2258 \\
\hline
\end{tabular}




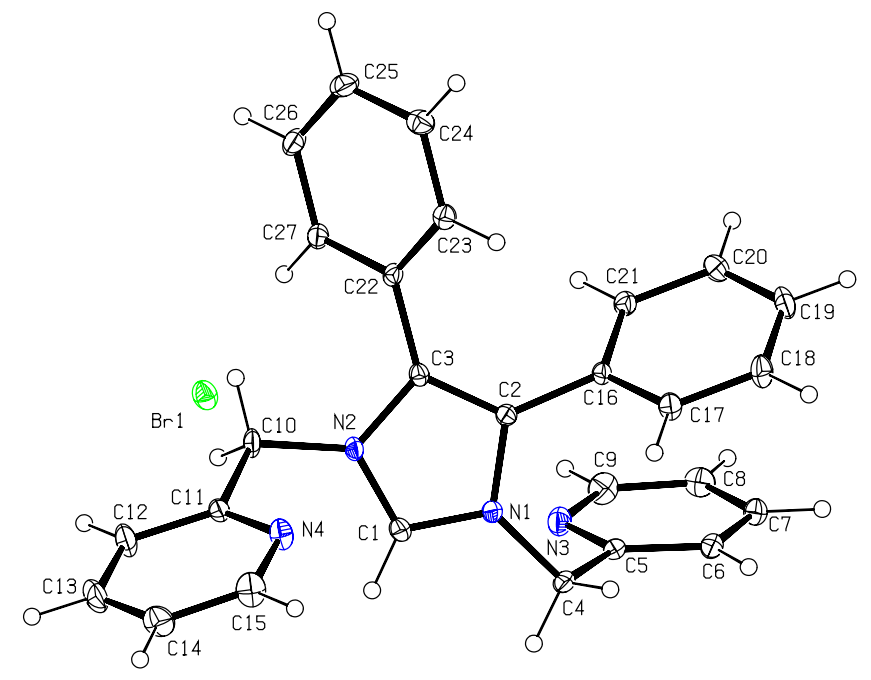

Figure 22: ORTEP representation of $\mathbf{1}$ with $30 \%$ probablilty ellipsoids.

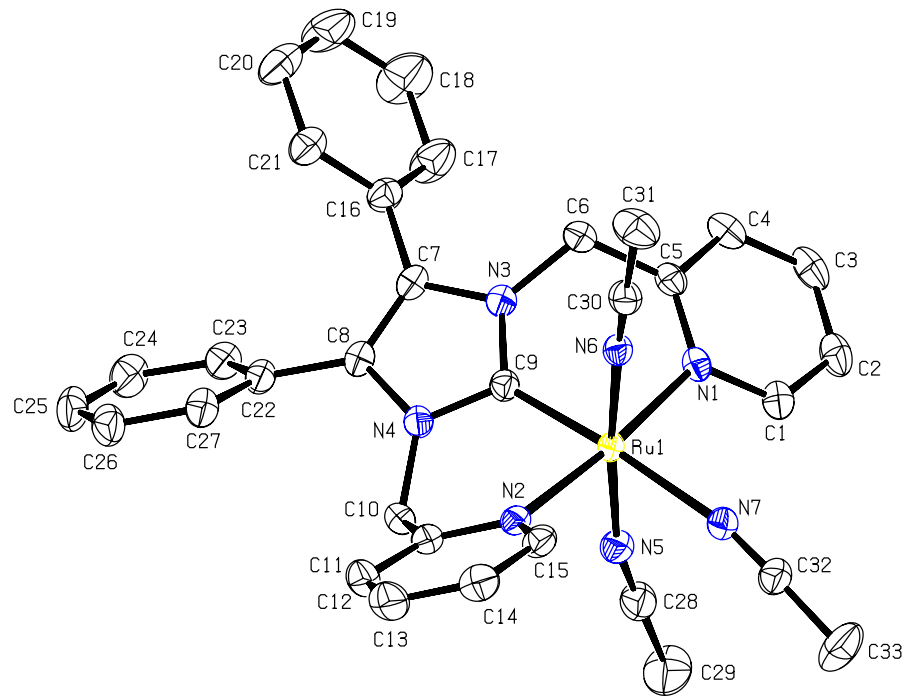

Figure 23: ORTEP representation of $\mathbf{3}$ with $30 \%$ probablilty ellipsoids. Hydrogen atoms and couteranions omitted for clarity. 


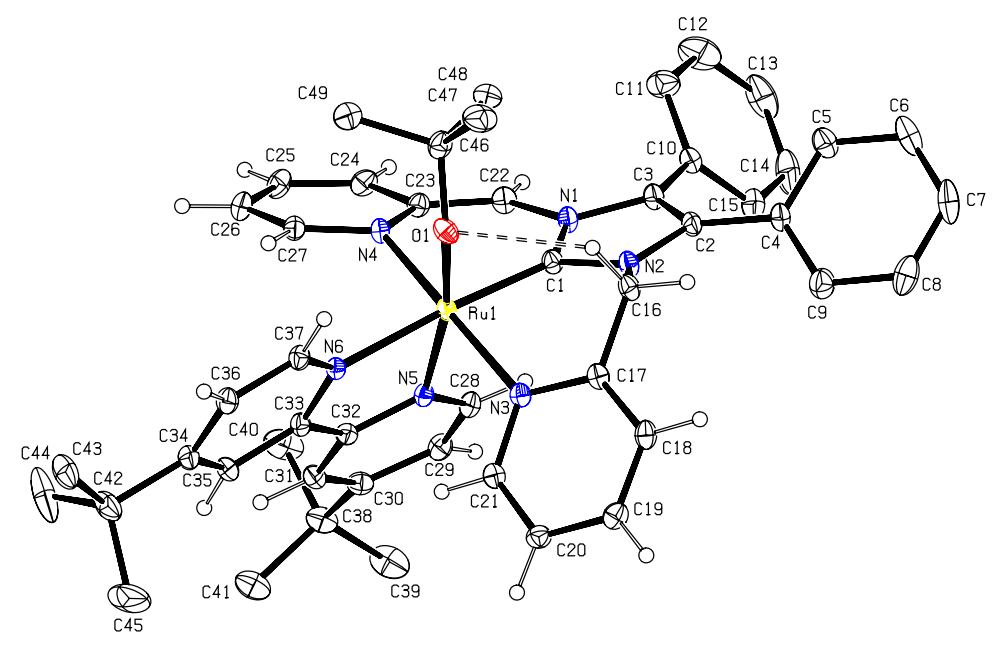

Figure 24: ORTEP representation of 6 with $30 \%$ probablilty ellipsoids. Most hydrogen atoms omitted for clarity.

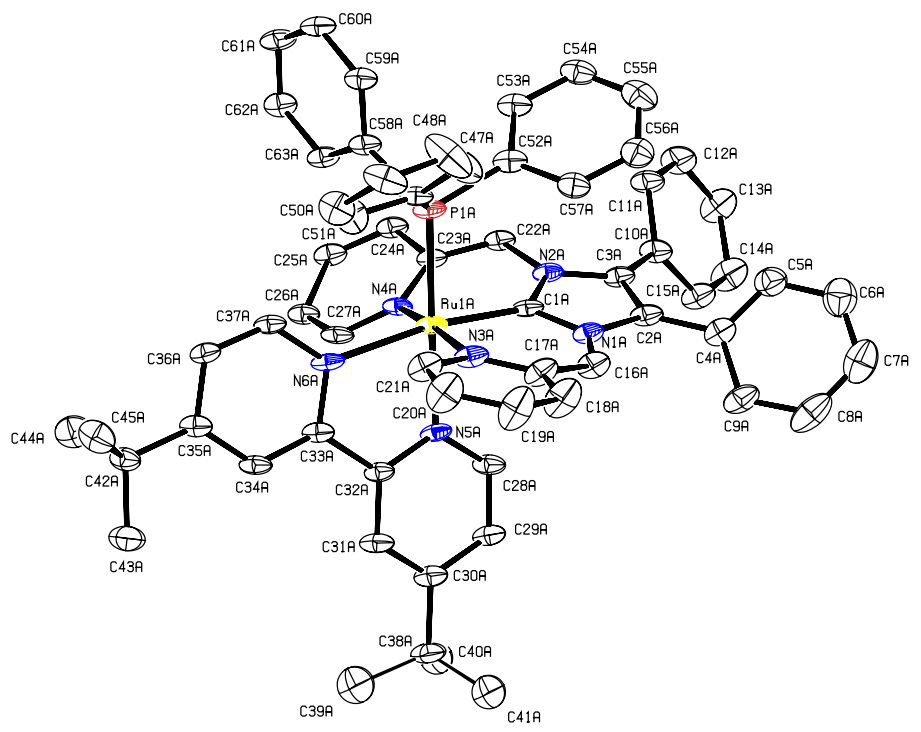

Figure 25: ORTEP representation of $\mathbf{8}$ with $30 \%$ probablilty ellipsoids. Both complexes within the asymmetric unit are disordered, only one is shown. Hydrogen atoms omitted for clarity. 


\section{DFT Data}

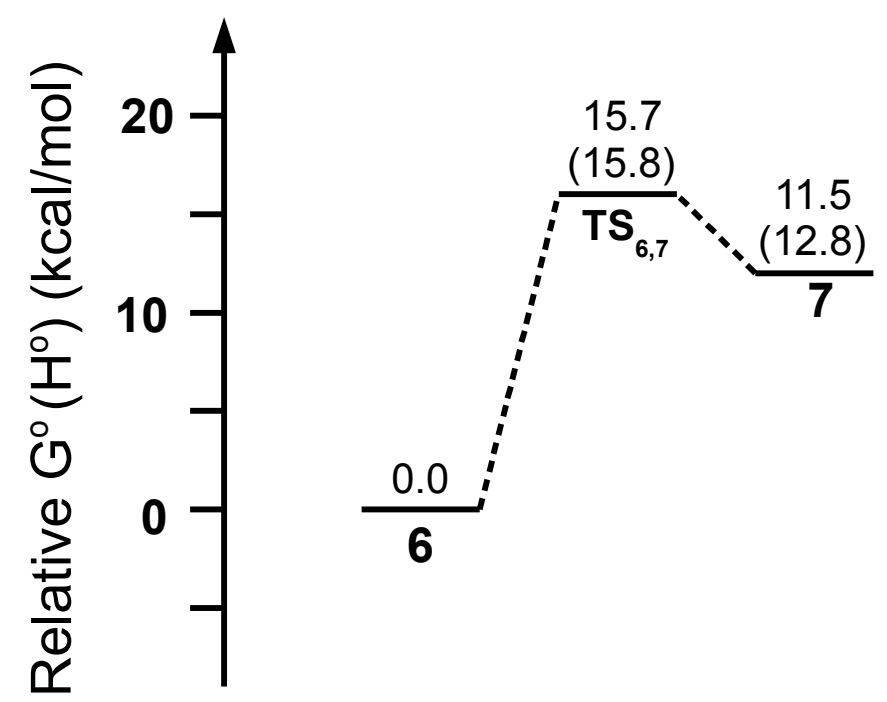

Figure 26: Free energy $\left(G^{\circ}, \mathrm{kcal} / \mathrm{mol}\right)$ diagram of $\mathbf{6}, \mathbf{T S}_{\mathbf{6}, 7}$, and 7. Enthalpies $\left(H^{\circ}, \mathrm{kcal} / \mathrm{mol}\right)$ are given in parentheses. 


\subsection{Cartesian Coordinates ( $(\AA)$, Free Energies $\left(G^{\circ}\right.$, Hartree), and En- thalpies $\left(H^{\circ}\right.$, Hartree) of Opti- mized Structures}

\begin{tabular}{llll} 
6 & \multicolumn{4}{l}{} & \\
$G^{\circ}$ & -2398.041900 & \\
$H^{\circ}$ & -2398.183040 & \\
$\mathrm{Ru}$ & -0.36653 & -0.81440 & 0.14196 \\
$\mathrm{O}$ & -0.11490 & -2.70185 & 0.98369 \\
$\mathrm{~N}$ & 2.15129 & 0.65403 & 0.82367 \\
$\mathrm{~N}$ & 2.49766 & -0.93937 & -0.60552 \\
$\mathrm{~N}$ & -0.07386 & -1.72238 & -1.76186 \\
$\mathrm{~N}$ & -0.59584 & 0.26571 & 1.95584 \\
$\mathrm{~N}$ & -1.10163 & 0.90828 & -0.71842 \\
$\mathrm{~N}$ & -2.48444 & -1.16405 & 0.06562 \\
$\mathrm{C}$ & 1.51261 & -0.33338 & 0.12734 \\
$\mathrm{C}$ & 3.73681 & -0.35004 & -0.38014 \\
$\mathrm{C}$ & 3.51845 & 0.65886 & 0.52685 \\
$\mathrm{C}$ & 4.96113 & -0.75717 & -1.05102 \\
$\mathrm{C}$ & 6.17365 & -0.82871 & -0.35239 \\
$\mathrm{H}$ & 6.18861 & -0.60566 & 0.70767 \\
$\mathrm{C}$ & 7.34256 & -1.19169 & -0.99899 \\
$\mathrm{H}$ & 8.26871 & -1.24246 & -0.43926 \\
$\mathrm{C}$ & 7.33033 & -1.50556 & -2.35276 \\
$\mathrm{H}$ & 8.24522 & -1.79497 & -2.85460 \\
$\mathrm{C}$ & 6.13495 & -1.44564 & -3.05662 \\
$\mathrm{H}$ & 6.11554 & -1.67921 & -4.11440 \\
$\mathrm{C}$ & 4.96399 & -1.07190 & -2.41723 \\
$\mathrm{H}$ & 4.04336 & -0.99395 & -2.98447 \\
$\mathrm{C}$ & 4.46980 & 1.61156 & 1.09424 \\
$\mathrm{C}$ & 4.56789 & 1.79229 & 2.47854 \\
$\mathrm{H}$ & 3.91061 & 1.23330 & 3.13476 \\
$\mathrm{C}$ & 5.50494 & 2.66184 & 3.01237 \\
$\mathrm{H}$ & 5.57012 & 2.78477 & 4.08667 \\
$\mathrm{C}$ & 6.36470 & 3.36456 & 2.17775 \\
$\mathrm{H}$ & 7.09723 & 4.04315 & 2.59721 \\
$\mathrm{C}$ & 6.27810 & 3.19306 & 0.80289 \\
$\mathrm{H}$ & 6.94160 & 3.74040 & 0.14426 \\
$\mathrm{C}$ & 5.33682 & 2.32973 & 0.26473 \\
$\mathrm{H}$ & 5.26718 & 2.20447 & -0.80943 \\
$\mathrm{H}$ & 1.22924 & -2.25979 & -1.15747 \\
$\mathrm{H}$ & -2.91441 & -0.33134 \\
$\mathrm{H}$ & -2.13556 & -2.65070 & -1.61090 \\
$\mathrm{H}$ & -2.23530 & -2.15938 \\
$\mathrm{H}$ & -2.73966 & -3.43562 \\
$\mathrm{H}$ & -2.73934 & -4.35069
\end{tabular}

$\begin{array}{llll}\mathrm{H} & 0.40840 & -3.13666 & -5.34781 \\ \mathrm{C} & -0.94424 & -2.20786 & -3.95123 \\ \mathrm{H} & -1.79398 & -2.17169 & -4.61952 \\ \mathrm{C} & -1.07146 & -1.71310 & -2.67008 \\ \mathrm{H} & -2.00696 & -1.28734 & -2.33527 \\ \mathrm{C} & 1.49214 & 1.53451 & 1.69109 \\ \mathrm{H} & 2.05941 & 2.40841 & 1.96558 \\ \mathrm{C} & 0.24022 & 1.34793 & 2.24056 \\ \mathrm{C} & -0.23409 & 2.33461 & 3.17324 \\ \mathrm{H} & 0.38333 & 3.21150 & 3.33002 \\ \mathrm{C} & -1.39271 & 2.16569 & 3.86231 \\ \mathrm{H} & -1.71752 & 2.91733 & 4.57284 \\ \mathrm{C} & -2.16016 & 0.99919 & 3.64879 \\ \mathrm{H} & -3.07516 & 0.80211 & 4.18926 \\ \mathrm{C} & -1.72156 & 0.12307 & 2.68955 \\ \mathrm{H} & -2.29902 & -0.76515 & 2.46582 \\ \mathrm{C} & -0.35940 & 1.93646 & -1.18118 \\ \mathrm{H} & 0.70838 & 1.76079 & -1.20690 \\ \mathrm{C} & -0.89338 & 3.13605 & -1.58132 \\ \mathrm{H} & -0.22151 & 3.91220 & -1.92574 \\ \mathrm{C} & -2.27786 & 3.35200 & -1.52604 \\ \mathrm{C} & -3.04316 & 2.28905 & -1.08019 \\ \mathrm{H} & -4.11837 & 2.38168 & -1.02283 \\ \mathrm{C} & -2.45853 & 1.08380 & -0.68873 \\ \mathrm{C} & -3.23058 & -0.07368 & -0.25124 \\ \mathrm{C} & -4.61866 & -0.11418 & -0.17020 \\ \mathrm{H} & -5.19009 & 0.77394 & -0.40743 \\ \mathrm{C} & -5.27990 & -1.27409 & 0.21999 \\ \mathrm{C} & -4.48491 & -2.38822 & 0.50224 \\ \mathrm{H} & -4.92349 & -3.32907 & 0.80393 \\ \mathrm{C} & -3.11027 & -2.29106 & 0.41666 \\ \mathrm{H} & -2.44102 & -3.11035 & 0.66555 \\ \mathrm{C} & -2.86253 & 4.69471 & -1.93813 \\ \mathrm{C} & -2.48979 & 4.97845 & -3.39728 \\ \mathrm{H} & -1.40929 & 5.00681 & -3.54310 \\ \mathrm{H} & -2.88914 & 5.94573 & -3.70812 \\ \mathrm{H} & -2.89659 & 4.21848 & -4.06685 \\ \mathrm{C} & -2.26674 & 5.78960 & -1.04582 \\ \mathrm{H} & -1.18067 & 5.83741 & -1.13381 \\ \mathrm{H} & -2.50780 & 5.61988 & 0.00497 \\ \mathrm{H} & -2.66500 & 6.76591 & -1.32876 \\ \mathrm{C} & -4.38097 & 4.72647 & -1.80522 \\ \mathrm{H} & -4.70459 & 4.55718 & -0.77676 \\ \mathrm{H} & -4.86263 & 3.98034 & -2.44001 \\ \mathrm{H} & -4.75709 & 5.70413 & -2.10937 \\ \mathrm{C} & -6.79944 & -1.28218 & 0.33562 \\ \mathrm{C} & -7.33387 & -2.64741 & 0.75385 \\ \mathrm{H} & -7.07656 & -3.42543 & 0.03305\end{array}$




$\begin{array}{llll}\mathrm{H} & -8.42191 & -2.61129 & 0.82138 \\ \mathrm{H} & -6.95555 & -2.95346 & 1.73060 \\ \mathrm{C} & -7.22059 & -0.24639 & 1.38405 \\ \mathrm{H} & -6.91383 & 0.76232 & 1.10409 \\ \mathrm{H} & -6.78458 & -0.46858 & 2.35959 \\ \mathrm{H} & -8.30656 & -0.24254 & 1.49601 \\ \mathrm{C} & -7.41538 & -0.90676 & -1.01598 \\ \mathrm{H} & -7.13758 & -1.62120 & -1.79282 \\ \mathrm{H} & -7.10066 & 0.08439 & -1.34536 \\ \mathrm{H} & -8.50465 & -0.89912 & -0.94446 \\ \mathrm{C} & 0.51727 & -3.13364 & 2.15439 \\ \mathrm{C} & 0.94334 & -4.58554 & 1.91805 \\ \mathrm{H} & 0.07702 & -5.19426 & 1.65053 \\ \mathrm{H} & 1.41170 & -5.03157 & 2.79974 \\ \mathrm{H} & 1.65613 & -4.64457 & 1.09174 \\ \mathrm{C} & 1.75346 & -2.31121 & 2.52541 \\ \mathrm{H} & 1.48479 & -1.26934 & 2.70875 \\ \mathrm{H} & 2.50008 & -2.33419 & 1.72838 \\ \mathrm{H} & 2.22737 & -2.70051 & 3.43092 \\ \mathrm{C} & -0.45863 & -3.09597 & 3.33702 \\ \mathrm{H} & -1.37988 & -3.62608 & 3.08342 \\ \mathrm{H} & -0.71872 & -2.06771 & 3.58930 \\ \mathrm{H} & -0.03929 & -3.56213 & 4.23376\end{array}$

$\mathbf{T S}_{6,7}$

$\begin{array}{llll}G^{\circ} & -2398.016771 & \\ H^{\circ} & -2398.158023 & \\ \mathrm{Ru} & 0.33887 & -0.65946 & -0.04123 \\ \mathrm{O} & -0.54178 & -2.52041 & -0.90277 \\ \mathrm{~N} & -2.13680 & 0.98215 & -0.52707 \\ \mathrm{~N} & -2.50702 & -0.81200 & 0.64133 \\ \mathrm{~N} & 0.03905 & -1.75120 & 1.76638 \\ \mathrm{~N} & 0.54483 & 0.57723 & -1.77815 \\ \mathrm{~N} & 1.28911 & 0.87800 & 0.86018 \\ \mathrm{~N} & 2.37930 & -1.24994 & -0.15703 \\ \mathrm{C} & -1.51892 & -0.06948 & 0.07632 \\ \mathrm{C} & -3.74358 & -0.22937 & 0.42203 \\ \mathrm{C} & -3.51695 & 0.90624 & -0.33023 \\ \mathrm{C} & -4.99668 & -0.78308 & 0.91917 \\ \mathrm{C} & -6.12981 & -0.83840 & 0.09942 \\ \mathrm{H} & -6.06062 & -0.49065 & -0.92465 \\ \mathrm{C} & -7.32784 & -1.34094 & 0.58016 \\ \mathrm{H} & -8.19262 & -1.37671 & -0.07128 \\ \mathrm{C} & -7.41919 & -1.80935 & 1.88449 \\ \mathrm{H} & -8.35553 & -2.20581 & 2.25729 \\ \mathrm{C} & -6.30042 & -1.76816 & 2.70653 \\ \mathrm{H} & -6.36333 & -2.12585 & 3.72723 \\ \mathrm{C} & -5.10236 & -1.25853 & 2.23259\end{array}$

$\begin{array}{llll}\mathrm{H} & -4.23949 & -1.20920 & 2.88690 \\ \mathrm{C} & -4.47132 & 1.87617 & -0.85606 \\ \mathrm{C} & -4.44098 & 2.26031 & -2.20273 \\ \mathrm{H} & -3.68178 & 1.84569 & -2.85594 \\ \mathrm{C} & -5.38066 & 3.14382 & -2.70773 \\ \mathrm{H} & -5.34401 & 3.42320 & -3.75383 \\ \mathrm{C} & -6.37403 & 3.65898 & -1.88438 \\ \mathrm{H} & -7.10826 & 4.34890 & -2.28179 \\ \mathrm{C} & -6.41857 & 3.28297 & -0.54861 \\ \mathrm{H} & -7.18719 & 3.68159 & 0.10264 \\ \mathrm{C} & -5.47541 & 2.40578 & -0.03742 \\ \mathrm{H} & -5.50981 & 2.12300 & 1.00810 \\ \mathrm{C} & -2.21958 & -2.18413 & 1.04295 \\ \mathrm{H} & -1.43308 & -2.57747 & -0.10827 \\ \mathrm{H} & -3.13580 & -2.69979 & 1.30493 \\ \mathrm{C} & -1.16639 & -2.34886 & 2.02197 \\ \mathrm{C} & -1.29311 & -3.21831 & 3.11511 \\ \mathrm{H} & -2.25025 & -3.69698 & 3.28272 \\ \mathrm{C} & -0.23348 & -3.43491 & 3.96813 \\ \mathrm{H} & -0.34085 & -4.09705 & 4.81872 \\ \mathrm{C} & 0.96364 & -2.76293 & 3.73777 \\ \mathrm{H} & 1.81835 & -2.87918 & 4.38949 \\ \mathrm{C} & 1.04804 & -1.93972 & 2.63496 \\ \mathrm{H} & 1.96645 & -1.41272 & 2.40590 \\ \mathrm{C} & -1.43707 & 1.94512 & -1.26670 \\ \mathrm{H} & -1.95027 & 2.88343 & -1.40110 \\ \mathrm{C} & -0.21286 & 1.75125 & -1.87388 \\ \mathrm{C} & 0.31625 & 2.82954 & -2.66621 \\ \mathrm{H} & -0.23096 & 3.76505 & -2.66418 \\ \mathrm{C} & 1.43879 & 2.68021 & -3.41642 \\ \mathrm{H} & 1.80331 & 3.50392 & -4.01965 \\ \mathrm{C} & 2.11701 & 1.44129 & -3.40600 \\ \mathrm{H} & 3.00145 & 1.26057 & -4.00045 \\ \mathrm{C} & 1.63898 & 0.46940 & -2.56568 \\ \mathrm{H} & 2.16649 & -0.47353 & -2.48575 \\ \mathrm{C} & 0.68452 & 1.91485 & 1.47630 \\ \mathrm{H} & -0.38818 & 1.82577 & 1.58638 \\ \mathrm{C} & 1.36284 & 3.02599 & 1.91307 \\ \mathrm{H} & 0.79986 & 3.82251 & 2.38265 \\ \mathrm{C} & 2.74831 & 3.13372 & 1.72837 \\ \mathrm{C} & 3.37090 & 2.05491 & 1.12515 \\ \mathrm{H} & 4.43939 & 2.06212 & 0.96421 \\ \mathrm{C} & 2.64692 & 0.93909 & 0.70738 \\ \mathrm{C} & 3.25888 & -0.25202 & 0.13329 \\ \mathrm{C} & 4.62100 & -0.41180 & -0.08697 \\ \mathrm{H} & 5.29103 & 0.41098 & 0.12758 \\ \mathrm{C} & 5.13175 & -1.60486 & -0.58894 \\ \mathrm{C} & 4.21226 & -2.63016 & -0.82465\end{array}$




\begin{tabular}{|c|c|c|c|c|c|c|c|}
\hline $\mathrm{H}$ & 4.52837 & -3.59446 & -1.19687 & $\mathrm{~N}$ & -2.12727 & 0.87388 & -0.60581 \\
\hline $\mathrm{C}$ & 2.86726 & -2.41451 & -0.59893 & $\mathrm{~N}$ & 0.09180 & -1.79371 & 1.78563 \\
\hline $\mathrm{H}$ & 2.12388 & -3.17956 & -0.79641 & $\mathrm{~N}$ & 0.57230 & 0.45361 & -1.81666 \\
\hline $\mathrm{C}$ & 3.48695 & 4.38556 & 2.17734 & $\mathrm{~N}$ & 1.23388 & 0.90486 & 0.85942 \\
\hline $\mathrm{C}$ & 3.28207 & 4.57820 & 3.68378 & $\mathrm{~N}$ & 2.43545 & -1.18223 & -0.11376 \\
\hline $\mathrm{H}$ & 2.22731 & 4.68015 & 3.94177 & $\mathrm{C}$ & -1.50963 & -0.12380 & 0.09493 \\
\hline $\mathrm{H}$ & 3.79263 & 5.48220 & 4.02100 & $\mathrm{C}$ & 1.15901 & -2.14389 & 2.53496 \\
\hline $\mathrm{H}$ & 3.68501 & 3.73631 & 4.24947 & $\mathrm{H}$ & 2.07418 & -1.61493 & 2.29838 \\
\hline $\mathrm{C}$ & 2.90891 & 5.59327 & 1.43141 & $\mathrm{C}$ & 1.14989 & -3.10142 & 3.51669 \\
\hline $\mathrm{H}$ & 1.84635 & 5.72726 & 1.63786 & $\mathrm{H}$ & 2.04973 & -3.32263 & 4.07252 \\
\hline $\mathrm{H}$ & 3.02790 & 5.48602 & 0.35180 & $\mathrm{C}$ & -0.05810 & -3.79725 & 3.73313 \\
\hline $\mathrm{H}$ & 3.42273 & 6.50677 & 1.73676 & $\mathrm{H}$ & -0.10958 & -4.59555 & 4.46467 \\
\hline C & 4.98240 & 4.30432 & 1.89234 & $\mathrm{C}$ & -1.16890 & -3.44376 & 3.03230 \\
\hline $\mathrm{H}$ & 5.18916 & 4.19476 & 0.82626 & $\mathrm{H}$ & -2.11651 & -3.94164 & 3.20078 \\
\hline $\mathrm{H}$ & 5.45510 & 3.47199 & 2.41723 & $\mathrm{C}$ & -1.14157 & -2.36356 & 2.08820 \\
\hline $\mathrm{H}$ & 5.47133 & 5.22011 & 2.22696 & $\mathrm{C}$ & -2.32696 & -1.96881 & 1.48889 \\
\hline $\mathrm{C}$ & 6.62456 & -1.73883 & -0.86328 & $\mathrm{H}$ & -3.24196 & -2.45543 & 1.78244 \\
\hline C & 6.99231 & -3.13198 & -1.36258 & $\mathrm{C}$ & -3.74162 & -0.17493 & 0.50026 \\
\hline $\mathrm{H}$ & 6.74100 & -3.90673 & -0.63606 & $\mathrm{C}$ & -3.50168 & 0.85519 & -0.38182 \\
\hline $\mathrm{H}$ & 8.06688 & -3.18648 & -1.54150 & $\mathrm{C}$ & -1.44455 & 1.79059 & -1.41409 \\
\hline $\mathrm{H}$ & 6.49328 & -3.37499 & -2.30219 & $\mathrm{H}$ & -1.98531 & 2.69995 & -1.61954 \\
\hline C & 7.02111 & -0.71231 & -1.93085 & $\mathrm{C}$ & -0.21458 & 1.59462 & -2.00224 \\
\hline $\mathrm{H}$ & 6.81937 & 0.30927 & -1.60535 & $\mathrm{C}$ & 0.28469 & 2.62679 & -2.87242 \\
\hline $\mathrm{H}$ & 6.47738 & -0.87854 & -2.86254 & $\mathrm{H}$ & -0.28362 & 3.54758 & -2.93361 \\
\hline $\mathrm{H}$ & 8.08843 & -0.78583 & -2.14832 & $\mathrm{C}$ & 1.40447 & 2.44644 & -3.61892 \\
\hline $\mathrm{C}$ & 7.40794 & -1.45404 & 0.42239 & $\mathrm{H}$ & 1.74871 & 3.23120 & -4.28289 \\
\hline $\mathrm{H}$ & 7.15003 & -2.16198 & 1.21184 & $\mathrm{C}$ & 2.10790 & 1.22442 & -3.52403 \\
\hline $\mathrm{H}$ & 7.21884 & -0.44862 & 0.80078 & $\mathrm{H}$ & 2.99004 & 1.01767 & -4.11346 \\
\hline $\mathrm{H}$ & 8.48032 & -1.53743 & 0.23653 & $\mathrm{C}$ & 1.66019 & 0.30842 & -2.60809 \\
\hline $\mathrm{C}$ & -1.04531 & -2.76031 & -2.22295 & $\mathrm{H}$ & 2.20958 & -0.61397 & -2.46582 \\
\hline $\mathrm{C}$ & -1.76129 & -4.10641 & -2.19463 & $\mathrm{C}$ & 0.57779 & 1.91701 & 1.46724 \\
\hline $\mathrm{H}$ & -1.08805 & -4.89188 & -1.84760 & $\mathrm{H}$ & -0.49049 & 1.78195 & 1.56651 \\
\hline $\mathrm{H}$ & -2.12228 & -4.38200 & -3.18734 & $\mathrm{C}$ & 1.20281 & 3.05438 & 1.91255 \\
\hline $\mathrm{H}$ & -2.62142 & -4.07857 & -1.52263 & $\mathrm{H}$ & 0.59961 & 3.82340 & 2.37796 \\
\hline $\mathrm{C}$ & -2.01513 & -1.66494 & -2.65450 & $\mathrm{C}$ & 2.58439 & 3.22342 & 1.74481 \\
\hline $\mathrm{H}$ & -1.51772 & -0.69477 & -2.68759 & $\mathrm{C}$ & 3.25863 & 2.17395 & 1.14617 \\
\hline $\mathrm{H}$ & -2.85942 & -1.59384 & -1.96400 & $\mathrm{H}$ & 4.32730 & 2.22813 & 0.99629 \\
\hline $\mathrm{H}$ & -2.41766 & -1.87470 & -3.64790 & $\mathrm{C}$ & 2.59105 & 1.02610 & 0.72191 \\
\hline $\mathrm{C}$ & 0.14077 & -2.81984 & -3.16886 & $\mathrm{C}$ & 3.26376 & -0.13834 & 0.16403 \\
\hline $\mathrm{H}$ & 0.82680 & -3.61792 & -2.87978 & $\mathrm{C}$ & 4.63332 & -0.23444 & -0.04892 \\
\hline $\mathrm{H}$ & 0.68637 & -1.87666 & -3.15799 & $\mathrm{H}$ & 5.26303 & 0.62102 & 0.16031 \\
\hline \multirow[t]{2}{*}{$\mathrm{H}$} & -0.18203 & -3.00850 & -4.19484 & $\mathrm{C}$ & 5.20350 & -1.40716 & -0.53476 \\
\hline & & & & $\mathrm{C}$ & 4.33648 & -2.47914 & -0.75930 \\
\hline 7 & & & & $\mathrm{H}$ & 4.70014 & -3.43212 & -1.11679 \\
\hline$G^{\circ}$ & \multicolumn{3}{|c|}{-2398.021565} & $\mathrm{C}$ & 2.98229 & -2.32654 & -0.53860 \\
\hline$H^{\circ}$ & \multicolumn{3}{|c|}{-2398.164775} & $\mathrm{H}$ & 2.28284 & -3.13457 & -0.72320 \\
\hline $\mathrm{Ru}$ & 0.37038 & -0.67721 & -0.01043 & $\mathrm{O}$ & -0.41166 & -2.63547 & -0.86765 \\
\hline $\mathrm{N}$ & -2.51284 & -0.77070 & 0.76532 & $\mathrm{H}$ & -1.10358 & -2.81106 & -0.20051 \\
\hline
\end{tabular}




$\begin{array}{llll}\mathrm{C} & -1.00198 & -2.95190 & -2.17565 \\ \mathrm{C} & 0.15710 & -3.00014 & -3.14433 \\ \mathrm{H} & 0.87904 & -3.76372 & -2.85298 \\ \mathrm{H} & -0.19958 & -3.23581 & -4.14705 \\ \mathrm{H} & 0.66466 & -2.03721 & -3.18794 \\ \mathrm{C} & -1.66799 & -4.30830 & -2.03454 \\ \mathrm{H} & -2.47159 & -4.27389 & -1.29500 \\ \mathrm{H} & -2.10514 & -4.62118 & -2.98295 \\ \mathrm{H} & -0.94860 & -5.06653 & -1.72400 \\ \mathrm{C} & -2.01002 & -1.88590 & -2.56356 \\ \mathrm{H} & -1.53310 & -0.90921 & -2.65063 \\ \mathrm{H} & -2.46290 & -2.13249 & -3.52527 \\ \mathrm{H} & -2.81297 & -1.81706 & -1.82576 \\ \mathrm{C} & -4.44887 & 1.77494 & -1.00157 \\ \mathrm{C} & -5.43629 & 2.40326 & -0.23373 \\ \mathrm{C} & -4.43316 & 2.00878 & -2.38277 \\ \mathrm{C} & -6.37557 & 3.23198 & -0.82640 \\ \mathrm{H} & -5.45947 & 2.23898 & 0.83711 \\ \mathrm{C} & -5.36926 & 2.84384 & -2.96998 \\ \mathrm{H} & -3.68715 & 1.51566 & -2.99558 \\ \mathrm{C} & -6.34508 & 3.45931 & -2.19567 \\ \mathrm{H} & -7.13021 & 3.70990 & -0.21334 \\ \mathrm{H} & -5.34365 & 3.00704 & -4.04073 \\ \mathrm{H} & -7.07635 & 4.11155 & -2.65700 \\ \mathrm{C} & -5.01356 & -0.64098 & 1.04349 \\ \mathrm{C} & -6.11330 & -0.82707 & 0.19772 \\ \mathrm{C} & -5.18111 & -0.88043 & 2.41292 \\ \mathrm{C} & -7.33765 & -1.23220 & 0.70443 \\ \mathrm{H} & -5.99806 & -0.65551 & -0.86628 \\ \mathrm{C} & -6.40496 & -1.29270 & 2.91457 \\ \mathrm{H} & -4.34537 & -0.72837 & 3.08549 \\ \mathrm{C} & -7.48894 & -1.46919 & 2.06410 \\ \mathrm{H} & -8.17521 & -1.37244 & 0.03188 \\ \mathrm{H} & -6.51525 & -1.46851 & 3.97784 \\ \mathrm{H} & -8.44482 & -1.79109 & 2.45859 \\ \mathrm{C} & 6.70208 & -1.47312 & -0.80154 \\ \mathrm{C} & 7.13540 & -2.85036 & -1.29213 \\ \mathrm{H} & 8.21207 & -2.85686 & -1.46655 \\ \mathrm{H} & 6.91681 & -3.63208 & -0.56258 \\ \mathrm{H} & 6.65163 & -3.12079 & -2.23231 \\ \mathrm{C} & 7.05774 & -0.43505 & -1.87239 \\ \mathrm{H} & 6.52494 & -0.62876 & -2.80518 \\ \mathrm{H} & 6.81154 & 0.57865 & -1.55315 \\ \mathrm{H} & 8.12795 & -0.46414 & -2.08601 \\ \mathrm{C} & 7.46354 & -1.14737 & 0.48762 \\ \mathrm{H} & 7.23562 & -1.86477 & 1.27769 \\ \mathrm{H} & 8.53971 & -1.17890 & 0.30782 \\ \mathrm{H} & 7.22274 & -0.15145 & 0.86150\end{array}$

$\begin{array}{llll}\mathrm{C} & 3.26295 & 4.50429 & 2.20632 \\ \mathrm{C} & 4.76491 & 4.48431 & 1.94609 \\ \mathrm{H} & 5.21097 & 5.41762 & 2.29192 \\ \mathrm{H} & 5.26151 & 3.66953 & 2.47628 \\ \mathrm{H} & 4.99390 & 4.38742 & 0.88333 \\ \mathrm{C} & 3.02595 & 4.68701 & 3.70940 \\ \mathrm{H} & 3.45157 & 3.86069 & 4.28130 \\ \mathrm{H} & 3.49608 & 5.60949 & 4.05529 \\ \mathrm{H} & 1.96398 & 4.74837 & 3.95012 \\ \mathrm{C} & 2.64744 & 5.68862 & 1.45249 \\ \mathrm{H} & 2.78971 & 5.59049 & 0.37482 \\ \mathrm{H} & 1.57666 & 5.77563 & 1.64091 \\ \mathrm{H} & 3.11592 & 6.62244 & 1.76924\end{array}$




\subsection{Full Gaussian 09 Reference}

Gaussian 09, Revision B.01 or D.01, M. J. Frisch, G. W. Trucks, H. B. Schlegel, G. E. Scuseria, M. A. Robb, J. R. Cheeseman, G. Scalmani, V. Barone, B. Mennucci, G. A. Petersson, H. Nakatsuji, M. Caricato, X. Li, H. P. Hratchian, A. F. Izmaylov, J. Bloino, G. Zheng, J. L. Sonnenberg, M. Hada, M. Ehara, K. Toyota, R. Fukuda, J. Hasegawa, M. Ishida, T. Nakajima, Y. Honda, O. Kitao, H. Nakai, T. Vreven, J. A. Montgomery, Jr., J. E. Peralta, F. Ogliaro, M. Bearpark, J. J. Heyd, E. Brothers, K. N. Kudin, V. N. Staroverov, R. Kobayashi, J. Normand, K. Raghavachari, A. Rendell, J. C. Burant, S. S. Iyengar, J. Tomasi, M. Cossi, N. Rega, J. M. Millam, M. Klene, J. E. Knox, J. B. Cross, V. Bakken, C. Adamo, J. Jaramillo, R. Gomperts, R. E. Stratmann, O. Yazyev, A. J. Austin, R. Cammi, C. Pomelli, J. W. Ochterski, R. L. Martin, K. Morokuma, V. G. Zakrzewski, G. A. Voth, P. Salvador, J. J. Dannenberg, S. Dapprich, A. D. Daniels, Ö. Farkas, J. B. Foresman, J. V. Ortiz, J. Cioslowski, and D. J. Fox, Gaussian, Inc., Wallingford CT, 2009. 